\title{
Federal Courts: Art. III(1), Art. I(8), Art. IV(3)(2), Art. II(2)/I(8)(3), and Art. II(1) Adjudication
}

Laura K. Donohue

Georgetown University Law Center, Ikdonohue@law.georgetown.edu

Jeremy M. McCabe

Georgetown University Law Center, jjm323@georgetown.edu

This paper can be downloaded free of charge from:

https://scholarship.law.georgetown.edu/facpub/2373

https://ssrn.com/abstract=3825670

\section{Forthcoming in Catholic University Law Review.}

This open-access article is brought to you by the Georgetown Law Library. Posted with permission of the author. Follow this and additional works at: https://scholarship.law.georgetown.edu/facpub

Part of the Administrative Law Commons, and the Courts Commons 


\title{
FEDERAL COURTS: ART. III(1), ART. I(8), ART. IV(3)(2), ART. II(2)/I(8)(3), AND ART. II(1) ADJUDICATION
}

\author{
Laura K. Donohue, J.D., Ph.D. and Jeremy McCabe, J.D.*
}

\begin{abstract}
The distinction among the several types of federal courts in the United States has gone almost unremarked in the academic literature. Instead, attention focuses on Article III "constitutional" courts with occasional discussion of how they differ from what are referred to as "non-constitutional" or "legislative" courts. At best, these labels are misleading: all federal courts have a constitutional locus, and most, but not all, federal courts are brought into being via legislation. The binary approach further ignores the full range of federal courts, which are rooted in different constitutional provisions: Art. III(1), Art. I(8); Art. IV(3); Art. II(2)/I(8)(3); and Art. II(1). These distinctions matter greatly in terms of defining jurisdiction and understanding the scope of the authorities - and constitutional protections - that apply. The failure of scholars to take into account the full panoply of the federal judicial system has contributed to inaccurate analyses and cabined the debate. This article takes a significant step forward, providing a conceptual, framework for each type of court and delineating, based on their legal and historical underpinning, which adjudicatory bodies in the history of the United States fall within each category. It details the constitutive elements of the courts and their jurisdiction as supported by doctrine, statutory law, and scholarly literature, providing the first, comprehensive taxonomy offederal courts in the United States.
\end{abstract}

\section{INTRODUCTION}

Throughout U.S. history, entities created under Article III(1) have been referred to as "constitutional courts." What characterizes them is that they share "in the exercise of the judicial power defined in [Art. III(2)], can be invested with no other jurisdiction, and have judges who hold office during good behavior, with no power in Congress to provide otherwise." In contrast, certain tribunals that do not meet the Article III requirements have been labelled "Article I," "legislative", or "non-constitutional" courts. These institutions are understood to be "created by Congress in the exertion of other powers," with their functions directed to specific ends and their judges holding office according to conditions set by Congress. ${ }^{2}$ While they may have some statutory protections, adjudicators in Article I tribunals are not constitutionally protected from removal during periods of good behavior; nor is their compensation guaranteed to remain undiminished during their tenure. ${ }^{3}$

The epithets employed to describe these two types of entities are deeply misleading. "Constitutional" (i.e., Article III) courts are not the only federal adjudicatory bodies constitutionally-grounded: every federal court finds its locus in the constitutional text. Nor are "legislative" (i.e., "Article I" courts) the only tribunals brought into being by legislation. All inferior Article III courts are created by Congress. Numerous other tribunals are rooted in Congress's Article I(8) enumerated powers. Some courts established by Congress, moreover, do not derive from Article I(8) enumerated powers at all, instead finding their locus in Article IV(3). Yet other entities, such as courts of occupation, have nothing to do with Congress but, under Article II, are constitutional federal courts nonetheless.

\footnotetext{
* Georgetown Law. Special thanks to Caitlin Chiaramonte, Kevin Jinks, Michel Paradis, Pete Pascucci, David Vladeck, and Brian Wolfman for their thoughtful comments on an earlier draft of this Article.

${ }^{1}$ Ex parte Bakelite Corp., 279 U.S. 438, 449 (1929).

${ }^{2}$ Ex parte Bakelite Corp., 279 U.S. 438, 449 (Van Devanter, J. Accord Williams v. United States, 289 U.S. 553, 563 (1933).

${ }^{3}$ Bakelite Corp., 279 U.S. at 449; Williams, 289 U.S. at 561, 581.
} 
The lack of precision has resulted in an inaccurate representation of what constitutes the federal judicial system. Casebooks and treatises largely ignore dozens of federal courts in existence. ${ }^{4}$ Even Hart and Wechsler, a canonical text, mentions just a handful of non-Article III entities and sidesteps any discussion of their constitutional underpinning. ${ }^{5}$ The lack of attention to the constituent parts of the system stunts our understanding of constitutional law, the history of the judiciary, the relationship among federal courts, and the extent — and limits — of their jurisdiction. It contributes to vague and inaccurate assertions. ${ }^{6}$ And it fuels the cumbrous and narrow debate about the legitimacy of assigning matters within the cases and controversies requirements of Article III to Article I entities. ${ }^{7}$ Scholars' failure to consider the full range of federal

\footnotetext{
${ }^{4}$ See, e.g., Michael Finch et Al., Federal Courts: Context, Cases, and Problems (3d ed. 2020) (incorporating only one chapter on non-Article III courts); MichaEL L. WeLlS ET AL., CASES AND MATERIALS ON FEDERAL COURTS (4th ed. 2019) (focusing almost entirely on Article III and the relationship between federal and state courts, with only cursory mention of legislative courts and administrative tribunals and no discussion of territorial courts, consular courts, military tribunals, or other non-Article III entities); Arthur D. Hellman et Al., Federal Courts: Cases and Materials on Judicial FEDERALISM AND THE LAWYERING PROCESS (4th ed. 2017) (defining "The Federal Judicial System" entirely in terms of Article III); LARRY W. YACKLE, FEDERAL COURTS: THE CURRENT Questions (2017) (narrowly discussing Article III entities); ERWIN CHEMERINSKY, FEDERAL JURISDICTION (6th ed. 2012) (adopting as its purpose "to state clearly the current law defining the jurisdiction of the federal courts," but then going on to focus solely on Article III); Charles Alan Wright AND MARY KAy Kane, The LAW OF Federal COURTS (7th ed. 2011) (addressing just Article III courts and their relationship to state courts); JAMES E. PFANDER, PRINCIPLES OF FEDERAL JURISDICTION (2d ed. 2011) (discussing only on Article III entities); RoBert A. CARP ET AL., The FEDERAL COURTS (5th ed. 2010) (making only cursory reference in the introductory chapter to "legislative courts" as entities created under Article I and omitting any reference to territorial courts, consular courts, or courts of occupation); LARRY W. YACKLE, FEDERAL COURTS 100-02, 118-31 (3d ed. 2009) (only one out of twelve chapters addressing "Non-Article III Adjudicative Bodies" in which cursory reference is made to a few examples).

${ }^{5}$ See Richard H. Fallon, JR. et al, Hart and Wechsler's The Federal Courts and the Federal SYSTEM 36-39 (7th ed. 2018) (very briefly mentioning Courts of the District of Columbia, territorial courts, the tax court, the court of federal claims, the court of veterans appeals, and military tribunals). ${ }^{6}$ See e e.g., Robert A. CARP ET AL., The Federal Courts (5th ed. 2010) (collapsing administrative tribunals and Article I(8) courts into the same category by suggesting that "legislative courts" often have "administrative and quasilegislative as well as judicial duties" and briefly mentioning in the same discussion the Foreign Intelligence Surveillance Court as a specialized court created by Congress without acknowledging it as an Article III entity); William Baude, Adjudication Outside Article III, 133 HARV. L. REV. 1511, 1522, 1549, 1558 (2020) (overlooking consular courts and courts of occupation, both of which exercise Article II power despite due process implications; referring to "so-called military courts" as "not really courts in the constitutional sense;" and asserting "[b]ankruptcy courts, military courts, the U.S. Tax Court, and the U.S. Court of Federal Claims are not courts, in the constitutional sense."); David J. Bederman, Article II Courts, 44 MERCER L. REV. 825, 833-34 (1993) (overlooking the role of Article II in the formation of consular courts); DAVID YANCEY THOMAS, A HiSTORY OF MILITARY GOVERNMENT IN NEWLY ACQUIRED TERRITORY OF THE UNITED STATES 317-18 (1904) (collapsing the extraterritorial court that operated in the Panama Canal Zone under an Article II/I hybrid model with Article I(8) military tribunals and referring to military commissions as "courts martial").

${ }^{7}$ For further discussion of the debate see, e.g., Baude, supra note 6 (distinguishing among certain courts as exercising either the judicial or the executive power); James E. Pfander, Article I Tribunals, Article III Courts, and the Judicial Power of the United States, 118 HARV. L. REV. 643 (2004) (arguing for an inferior tribunal reading of Art. I(8)(9) to support the existence of both Article III and I entities); Craig A. Stern, What's a Constitution Among Friends?-Unbalancing Article III, 146 U. PA. L. Rev.1043, 107374 (1998) (distinguishing between judicial and executive power to explain the Article III/Article I divide); Gary Lawson, Territorial Governments and the Limits of Formalism, 78 CALIF. L. REV. 853, 887-892 (1990) (challenging the legitimacy of territorial courts and referring to Marshall's decision in Am. Ins. Co. v. 356 Bales of Cotton (Canter), 26 U.S. (1 Pet.) 511 (1828) as "fatuous"); Paul M. Bator, The Constitution as Architecture: Legislative and Administrative Courts Under Article III, 65 IND. L.J. 233, 235-36 (1990) (arguing the existence of non-Article III courts as a matter of history and expediency, not constitutional fidelity); MARTIN H. REDish, FEDERAl JuRISDICTION: TENSIONS IN THE ALLOCATION OF
} 
courts has led to inaccurate characterizations of what constitutes federal judicial power. While some entities may have recourse to Article III entities as an appellate matter (and thus carry "the judicial power of the United States"), not all of them do-nor need they, as a constitutional matter, in order to exercise $a$ judicial power.

This Article, accordingly, provides the first comprehensive account of the federal judicial system, which includes general and specialized Article III(1) courts; specialized Article I(8) enumerated powers courts; Article IV(3) territorial courts; Article II(2)/I(8)(3) treaty-based courts; and Article II(1) courts of occupation. It defines and distinguishes these from each other and from administrative tribunals, providing in the process a robust account of the scope of the judiciary and demonstrating that the system is far more complex than the simple binary approach that has hitherto marked scholarly discussion. In so doing, it challenges existing theoretical constructs that mark the field.

Part II begins by detailing the eight Article III(1) courts that currently operate, five of which have specialized subject matter jurisdiction. ${ }^{8}$ It recognizes numerous specialized Article III courts that are no longer in existence and acknowledges that all Article III(1) courts have inherent powers that stem from their duty to ensure fairness and justice in the course of adjudication, their ability to efficiently manage their resources, and their interest in protecting the integrity, independence, and reputation of the courts as an institution. ${ }^{9}$ These powers do not depend on any statute. They arise from the courts qua Article III entities. In recognition of separation of powers, those that go to the core of the court acting in its judicial capacity are beyond the reach of either Congress or the Executive Branch.

In Part III, we turn to specialized courts established under Congress's Article I(8) enumerated powers. While much has been made of the relationship between Article I(8)(9), granting Congress the power to create tribunals inferior to the Supreme Court, and Article III entities, almost no attention has been paid to the relationship of Article $\mathrm{I}(8)(9)$ to the other elements of Article I(8) which provide further constitutional grounding. Article I(8)(17) provides a locus for Courts of the District of Columbia (the

JUDICIAL POWER 36-39 (2d ed. 1990) (attacking territorial courts and arguing that military tribunals are best considered as part of Article III); Richard H. Fallon, Jr., Of Legislative Courts, Administrative Agencies, and Article III, 101 HARV. L. REV. 915, 916 (1988) (embracing the appellate review theory); Martin H. Redish, Legislative Courts, Administrative Agencies, and the Northern Pipeline Decision, 1983 DUKE L. J. 197 (presenting criteria for Article III versus administrative agency adjudication); David P. Currie, The Constitution in the Supreme Court: The Powers of the Federal Courts, 1801-1835, 48 U. CHI. L. Rev. 646, 719 (1982) (critiquing Chief Justice John Marshall's decision in Canter as to the legitimacy of a territorial court as "difficult to reconcile with the purposes of Article III" while sidestepping the potential locus of Congressional authority as Article IV).

${ }^{8}$ The five include the Foreign Intelligence Surveillance Court; the Foreign Intelligence Surveillance Court of Review; the Alien Terrorist Removal Court, the U.S. Court of Appeals for the Federal Circuit, and the U.S. Court of International Trade.

${ }^{9}$ For scholarly discussion of essential inherent powers, see Amy Coney Barrett, Procedural Common Law, 94 VA. L. Rev. 813 (2008), Robert J. Pushaw, Jr., The Inherent Powers of the Federal Courts and the Structural Constitution, 86 IowA L. Rev. 735 (2001), and Sara Sun Beale, Reconsidering Supervisory Power in Criminal Cases: Constitutional and Statutory Limits on the Authority of the Federal Courts, 84 Colum. L. REV. 1433 (1984). To the extent that scholars disagree, it is in how broadly such powers should be understood. Some say any action bearing a natural relation to the administration of justice falls exclusively within the purview of the courts. See, e.g., Joseph J. Anclien, Broader Is Better: The Inherent Powers of Federal Court, 64 N.Y.U. ANN. SuRv. AM. L. 37, 53 (2008); Linda Mullenix, Unconstitutional Rulemaking: The Civil Justice Reform Act and Separation of Powers, 77 MinN. L. REv. 1283, 1320-22 (1993). 
Superior Court and the Court of Appeals). ${ }^{10}$ In the military sphere, nine tribunals find their homes in Articles I(8)(10), (11), (14), and (16). They divide into three categories: the courts-martial system regulates servicemembers ${ }^{11}$; military commissions apply to civilians and enemy combatants ${ }^{12}$; and veterans courts adjudicate retired servicemembers' benefits. The U.S. Court of Federal Claims and U.S. Tax Court both derive from Article I(8)(1), with the U.S. Bankruptcy Courts and Bankruptcy Appellate Panels as well as the (now defunct) citizenship courts from Article I(8)(4). ${ }^{13}$ Because Article III powers do not extend to Article I tribunals, litigants in the latter have access as of right to an Article III appellate court. ${ }^{14}$

Article I is not the only source of Congressional power to constitute judicial entities. Part IV, accordingly, turns to Article IV(3)(2), which provides for Congress "to dispose of an make all needful Rules and Regulations respecting the Territory or other Property belonging to the United States." 15 This clause provides independent authority for adjudication of disputes outside of Article III-a power that has been conspicuously overlooked in the effort to shoehorn federal courts into the "Article III or Article I" nomenclature. Two categories mark this area: the first, incorporated territorial courts, operated in nearly every state (outside of the original thirteen colonies), prior to admission to the union; the second relates to unincorporated land, in which Congress has established a number of parallel courts. The three currently in existence feed into Article III(1).

Part V turns to treaty-based courts, which derive from Article II(2) coupled with Congress's commerce authority under Article I(8)(3). Unlike territorial courts, in regard to which Congress acts as the first mover, courts in this category depend on the Executive to negotiate international agreements, subsequent to which Congress acts first to ratify the treaty and then to implement its requirements. Consular courts come within this category, as do other entities established by Congress consistent with diplomatic agreements, which are not housed in the country with whom the agreement was reached. With a couple of exceptions (i.e., the U.S. Court of China and the Court of Private Land Claims, which dealt with title to lands transferred to the United States following the Mexican-American War), treaty-based courts have been insulated from Article III(1) adjudication.

Part VI examines Article II courts of occupation and expansion, which the President establishes in the context of war in occupied territories. Far from being a relic of the past, at least four such courts operated in the twentieth century. None is supported by legislation. Instead, they rely wholly on the President's Article II(1) powers. In some cases, these tribunals have acted as a forerunner to territorial courts established by Congress under Article IV(3)(2). The divide into three categories: courts established in

\footnotetext{
${ }^{10}$ The constitutional nexus for the Court is considered to be U.S. ConST. art. I, $\S 8$, cl. 17. But note that the District of Columbia courts' statuses have alternated over history. See discussion infra Part III.A. ${ }^{11}$ See O'Callahan v. Parker, 395 U.S. 258, 265 (1969), overruled by Solorio v. United States, 483 U.S. 435, 436 (1987) (holding that trying a member of the Armed Forces under the UCMJ does not require the offense charged to have a service connection).

${ }^{12}$ See In re Khadr, 823 F.3d 92, 96 (D.C. Cir. 2016); Khadr v. United States, 62 F. Supp. 3d 1314, 1316 (C.M.C.R. 2014).

${ }^{13}$ See U.S. Const. art. I, § 8, cls. 8, 1, 4.

${ }^{14}$ See Stern v. Marshall, 564 U.S. 462, 494-95 (2011).

${ }^{15}$ U.S. CONST. art. IV, $\S 2$, cl. 3.
} 
land acquired by the United States, courts established in response to armed rebellion, and courts created in the context of war.

In Part VII, we briefly address administrative tribunals, which depart from specialized Article I(8) courts by the degree of independence they have from the Executive. Numerous such entities provide appeals of executive agency decisions or themselves constitute independent, quasi-judicial agencies. Some examples include: the U.S. Immigration Courts, the Board of Immigration Appeals, the Board of Veterans' Appeals, the U.S. International Trade Commission, the Social Security Administration's Appeal Council, the Federal Trade Commission, the Federal Election Commission, and the National Labor Relations Board.

The final section, Part VIII, underscores that the federal judicial structure is far more complex than is generally acknowledged. Accounts that narrowly focus on the interplay between Article III and Article I(8)(9) miss the independent power of Congress to establish adjudicatory bodies pursuant to its other authorities. Similarly absent are considerations about other constitutional authorities that give rise to different types of courts. Trying to justify the difference by according judicial power to territories as a separate government may seem attractive, but it fails to account for the impact on citizens' rights. No more so does it explain treaty-based or consular courts, or even courts of occupation. What does account for these entities is the fact that they are rooted in different constitutional powers and part of an intricate system of adjudication.

\section{THE JUdiCIAL BRANCH: ARTICLE III(1) COURTS}

Article III(1) provides for the judicial Power to be vested in the Supreme Court "and in such inferior Courts as the Congress may from time to time ordain and establish." 16 Under this power, the legislature has established both non-specialized and specialized Article III courts. Their status conveys certain inherent authorities that are constitutionally-derived and indelibly linked to the courts' status as a co-equal branch of government. The fact that some of these courts are geographically-limited, or established with particular subject-matter in mind, does nothing to divest them of their Article III authority as the judicial power of the United States.

Once created, Article III courts "share in the exercise of judicial power defined in [Article III]." ${ }^{\text {"17 }}$ All Article III judges are guaranteed life tenure, removal only for good cause, and undiminished compensation. ${ }^{18}$ Unlike most state courts, all Article III Courts are courts of limited jurisdiction. ${ }^{19}$ They have authority over nine categories of cases and controversies, which divide into two general categories: the nature of the cause and the character of the parties. ${ }^{20}$ The "judicial power" exercised in relation to them is "the power of a court to decide and pronounce a judgment and carry it into effect between persons and parties who bring a case before it for decision." 21 Cabined by the constitutional tenets, the meaning assigned to "cases" and "controversies" therefore at once establishes federal jurisdiction and, along with the contours set by statute,

${ }^{16}$ U.S. CONST. art III, $\S 1$.

${ }^{17}$ Ex parte Bakelite Corp., 279 U.S. 438, 449 (1929).

${ }^{18} \mathrm{Id}$.

${ }^{19}$ See Turner v. Bank of N. Am., 4 U.S. (4 Dall.) 8, 10 (1799).

${ }^{20}$ See U.S. Const. art. III, § 2; Cohens v. Virginia, 19 U.S. (6 Wheat.) 264, 378 (1821).

${ }^{21}$ Muskrat v. United States, 219 U.S. 346, 356 (1911). 
determines the extent of the judicial power. The Supreme Court has, at times, read the clause broadly to encompass cases that turn on a "federal ingredient." 22

\section{A. Non-Specialized Geographic Courts}

Non-specialized Article III courts are the courts one generally thinks of when contemplating the "federal judiciary": namely, the Supreme Court, Circuit Courts of Appeals, the District Courts, and the (now defunct) Circuit Courts. ${ }^{23}$ Although all federal courts have some level of specialization of subject matter, Congress granted these courts (save the Supreme Court) with jurisdiction based on geographic location. ${ }^{24}$

The Supreme Court, subject to the case-or-controversy requirement, exercises absolute authority over the U.S. Constitution, treaties, and federal statutory law. It understands this requirement to mean that Article III courts may not issue advisory opinions and the matter in question must satisfy standing and ripeness, not be moot, and not present a "political question." 25 The Court also exercises jurisdiction over matters involving federal common law, with due deference to comity and respect for state authorities. ${ }^{26}$ Congress has assigned the Supreme Court original and exclusive jurisdiction of all controversies between two or more states and original (but not exclusive) jurisdiction of all actions in which ambassadors or public officials of foreign states are party, all controversies between the states and the federal government, and all actions by a state against citizens of another state or aliens. ${ }^{27}$ The Court has the authority to review (by certiorari) all cases in the Courts of Appeal as well as all federal questions decided via state courts of last resort. ${ }^{28}$ It has jurisdiction over decisions from the District of Columbia Court of Appeals, ${ }^{29}$ the Supreme Court of the Commonwealth of Puerto Rico, ${ }^{30}$ and the supreme court of the Virgin Islands, ${ }^{31}$ as well as the specialized Article III courts and certain decisions of the [Article I(8)] U.S. Court of Appeals for

\footnotetext{
22 See Osborn v. Bank of the U.S., 22 U.S. (9 Wheat.) 738, 824 (1824). Note, however, that to the extent that Osborn is good law, it is because it is considered an expression of protective jurisdiction-i.e., a reading of "arising under" to protect vital federal interest. See Verlinden B.V. v. Cent. Bank of Nigeria, 461 U.S. 480, 492-93 (1983). After Louisville \& N.R. Co. v. Mottley, however, the "ingredient" argument has taken a back seat and the Court has in general taken a more restrained view of what constitutes a claim "arising under" federal law. See Louisville \& Nashville R.R. Co. v. Mottley, 211 U.S. 149, 152-53 (1908).

${ }^{23}$ See U.S. ConST. art. III, $\S 1$; Judiciary Act of 1789, ch. 20, §§ 2-4, 1 Stat. 73, 73-75; Judiciary Act of 1891 , ch. 517, § 2, 26 Stat. 826, 826.

${ }^{24}$ See Judiciary Act of $1789 \S \S 9,11-12,1$ Stat. at 76-77, 78-80 (district and circuit courts); Judiciary Act of $1891 \S 6,26$ Stat. at 828. While it is recognized that the Court of Appeals for the District of Columbia has a different docket load than other regional circuits, we have included it within the non-specialized sets of courts. See, e.g., Eric M. Fraser et al. The Jurisdiction of the D.C. Circuit, 23 Cornell J.L. \& Pub. POL'Y 131 (2013) (discussing the Court's unique workload resulting from the Court's location, its geographic coverage compared to other regional circuits, and Congress's penchant for giving the Court exclusive appellate jurisdiction in many different types of cases).

${ }^{25}$ See Letter from the Supreme Court Justices to President George Washington (Aug. 8, 1793) (establishing no advisory opinions); Marbury v. Madison, 5 U.S. (1 Cranch) 137, 170 (1803) (establishing political-question doctrine); Flast v. Cohen, 392 U.S. 83, 96-97 (1968) (acknowledging the Article III "prohibition against advisory opinions").

${ }^{26}$ See, e.g., Murdock v. City of Memphis, 87 U.S. (20 Wall.) 590, 626 (1874) (refraining from reviewing state common law not as a matter of Constitutional jurisdiction but out of comity).

2728 U.S.C.A. $\$ 1251$ (West).

${ }^{28}$ Id. $\S \S 1254(\mathrm{a}), 1257$.

${ }^{29}$ Id. $\$ 1257(\mathrm{~b})$.

${ }^{30}$ Id. $\S 1258$.

${ }^{31}$ Id. $\S 1260$.
} 
the Armed Forces. ${ }^{32}$ Although originally established with one chief justice and five associate justices appointed by the President with the advice and consent of the Senate, under the Judiciary Act of 1869, the Court expanded to include its current number of one chief justice and eight associate justices. ${ }^{33}$

The Courts of Appeal and District Courts serve as inferior, non-specialized and geographically-limited courts. ${ }^{34}$ The former is constituted by 179 judges appointed by the President with the advice and consent of the senate. ${ }^{35}$ Like those on the Supreme Court, they have life tenure and salary protection. ${ }^{36}$ They are divided into 12 regional circuits, ${ }^{37}$ which encapsulate 91 district courts. ${ }^{38}$ The 663 judges appointed to the District Courts have the same constitutional protections extended to the Supreme Court and the Courts of Appeal. ${ }^{39}$

Two primary statutes establish subject matter jurisdiction for the District Courts, granting them original jurisdiction over federal questions (i.e., "all civil actions arising under the Constitution, laws, or treaties of the United States") as well as disputes between and among citizens of different states (i.e., diversity jurisdiction). ${ }^{40}$ Several provisions detail jurisdiction of constitutionally-enumerated federal questions, ${ }^{41}$ provide additional bases for the suit authorized under Article III. ${ }^{42}$ Congress restricted the ability of Article III courts to act on certain matters until they have first worked their way through the state judicial domain. ${ }^{43}$

The (now defunct) Circuit Courts (1789-1912) were Article III courts that ran in tandem with district courts. The Circuit Courts, which served as both trial courts and had appellate jurisdiction, were created by the Judiciary Act of 1789. In 1891, the Court of Appeals was established as an appellate court for district courts and circuit courts. ${ }^{44}$

\section{B. Specialized Courts}

Congress's authority to create lower courts and to set their subject-matter jurisdiction "necessarily implies the power to limit the jurisdiction of those Courts to particular objects." ${ }^{45}$ As with non-specialized and geographically-focused Article III

\footnotetext{
${ }^{32}$ Id. § 1259.

${ }^{33}$ Judiciary Act of 1789, ch. 20, § 1, 1 Stat. 73, 73; Judiciary Act of 1869, ch. 22, § 1, 16 Stat. 44, 44.

${ }^{34} 28$ U.S.C.A. $\S \S 41,43, \S \S 81-132$. U.S. Const. art. III, § 1. See also Judiciary Act of 1789, ch. 20, §§

2-3, 1 Stat. 73, 73-74; Judiciary Act of 1891, ch. 517, § 2, 26 Stat. 826, 826; District of Columbia Court

Reorganization Act of 1970, Pub. L. No. 91-358, 84 Stat. 473, 475.

${ }^{35}$ See 28 U.S.C.A. $\S 44$. Note that there are only 167 judges excluding the specialized Court of Appeals for the Federal Circuit.

${ }^{36}$ U.S. CONST. art. III, $\S 1$.

${ }^{37}$ See id.

${ }^{38}$ See id. $\S 133$. The district courts in Guam, the Northern Mariana Islands, and the Virgin Islands are not included in 28 U.S.C.A. $\S 133$ as they are courts established under Article IV of the Constitution.

${ }^{39}$ U.S. CONST. art. III, § 1; see 28 U.S.C.A. § 133.

4028 U.S.C.A. $\$ \S 1331-1332$.

${ }^{41}$ See id. $\$ \$ 1330-1369$.

${ }^{42}$ See id. $\$ 1367$ (supplemental jurisdiction). A district court having original jurisdiction over a civil action shall have jurisdiction over all other claims that are so related to the action as to form part of the same case or controversy under Article III. Id. § 1367(a).

${ }^{43}$ See, e.g., 28 U.S.C.A. $\$ 1341$ (taxes by states); id. § 1342 (rate orders of state agencies).

${ }^{44}$ Judiciary Act of 1891, ch. 517, 26 Stat. 826. The circuit courts were abolished by the Judicial Code of 1911, ch. 231, § 289, 36 Stat. 1087, 1167.

${ }^{45}$ United States v. Hudson, 11 U.S. (7 Cranch) 32, 33 (1812).
} 
courts, those with specialized subject-matter jurisdiction carry the judicial power of the United States. The requirements of unity, supremacy, and inferiority having been met, the judicial protections of good behavior and set compensation respected, and the case or controversy requirement satisfied, such entities carry the full power of the third branch of government. Scholars and the Courts agree that it is "uncontroversial that the lower courts described in Article III, and created by Congress pursuant to Article I, § 8, exercise the judicial power of the United States described in Article III, § 2." ${ }^{\prime \prime}$ Accordingly, interference by the other branches in the core functioning of Article III courts, of any type, violates separation of powers. There are currently six federal Article III specialized courts. At least seven additional specialized courts have at one point been brought into existence by Congress. ${ }^{47}$

\section{Foreign Intelligence Surveillance Court and Court of Review}

Two of the most prominent specialized Article III courts in existence are the Foreign Intelligence Surveillance Court (FISC) and Foreign Intelligence Surveillance Court of Review (FISCR). Congress created them in 1978 to act as a neutral, third party arbiter in approving the collection of domestic electronic surveillance undertaken for foreign intelligence purposes. ${ }^{48}$ Their creation responded to public outcry at the extent to which the intelligence community had placed U.S. citizens under surveillance, as well as the Supreme Court's determination that the executive could not engage in electronic surveillance for domestic security purposes without some judicial process. ${ }^{49}$ Despite its in camera, ex parte emphasis and the absence of adversary parties, from the beginning, Congress has consistently considered FISC/FISCR to be an Article III court. ${ }^{50}$ Every court to confront the question has agreed. ${ }^{51}$

\footnotetext{
${ }^{46}$ David A. Case, Article I Courts, Substantive Rights, and Remedies for Government Misconduct, 26 N. ILL. U. L. ReV. 101, 104-05 (2005); see Turner v. Bank of N. Am., 4 U.S. (4 Dall.) 8, 10 (1799); United States v. Hudson, 11 U.S. (7 Cranch) 32, 33 (1812).

47 The U.S. Customs Court, Court of Customs and Patent Appeals, Emergency Court of Appeals, Temporary Emergency Court of Appeals, the Commerce Court, the Special Railroad Court, and the Court of Claims.

${ }^{48}$ See Foreign Intelligence Surveillance Act of 1978, Pub. L. No. 95-511, 92 Stat. 1783 (codified as amended at 50 U.S.C.A. $\$ \S 1801-1885$ c).

${ }^{49}$ See id. §103(a), 92 Stat. at 1788; Intelligence Activities: Senate Resolution 21: Hearings Before the S. Select Comm. to Study Governmental Operations with Respect to Intel. Activities of the U.S., 94th Cong., vol. 5, at 1 (1975); United States v. U.S. Dist. Ct., 407 U.S. 297, 321 (1972). The law provides special protections for United States persons. See 50 U.S.C.A. $\S$ 1801(h)(2), (4), 1802(a)(1)(B), 1821(4)(D), 1822(a)(1)(A)(ii).

${ }^{50}$ Foreign Intelligence Electronic Surveillance: Hearings Before the Subcomm. on Legis. of the H. Permanent Select Comm. on Intel., 95th Cong. 26 (1978) (Letter from John M. Harmon, Assistant Att'y Gen., to Rep. Edward P. Boland (Apr. 18, 1978), stating FISC/FISCR "will be Article III courts"); id. at 116 (FISC, comprised of "article III judge[s]" is to be independent "and in no way dependent on the executive branch of Government"); id. at 184 (Letter from Sen. Edward M. Kennedy to the Rep. Robert McClory (Feb. 10, 1978), stating that FISC is considered within "the constitutional jurisdiction of Article III courts."); see also id. at 213-16, 224 (discussions relating to whether the issues before the court would meet Article III requirements as cases or controversies). It continues to do so. See 154 ConG. REC. 804 (2008) (statement of Sen. Russell D. Feingold, alluding to FISC as an Article III court with "inherent power" over its own records and balking at the idea that the administration could "withhold FISA Court opinions and documents that include significant interpretations of law"); see also id. at 809 (statement of Sen. Sheldon Whitehouse); ANDrew Nolan \& Richard M. ThOMPSOn II, Cong. Rsch. SERV., R43746, Congressional Power to Create Federal Courts: A Legal Overview 6 (2014).

${ }^{51}$ See, e.g., In re Certification of Questions of L. to the Foreign Intel. Ct. of Rev., No. FISCR 18-01, GID.CA.00006, at 8, 2018 WL 2709456, at*4 (FISA Ct. Rev. Mar. 16, 2018) (per curiam); In Re Motion for Release of Ct. Recs., 526 F. Supp. 2d 484, 486, GID.C.00021, at 3 (FISA Ct. 2007); In re Sealed Case, 310 F.3d 717, 731-32, GID.CA.00001, at 731-32 (FISA Ct. Rev. 2002) (per curiam); United States
} 
The role of the court has altered over time. Initially comprised of seven judges selected by the Chief Justice from seven of the United States judicial circuits, ${ }^{52}$ FISC's job was to ascertain whether the government had met its burden of establishing probable cause that the target was a foreign power or an agent of a foreign power, and likely to use the facility to be placed under surveillance, prior to issuing orders. ${ }^{53}$ FISCR, comprised of three judges designated by the Chief Justice from the United States district courts or courts of appeal, was fashioned to serve in an appellate fashion. ${ }^{54}$ In cases in which FISCR denies an application, the Government could file a petition for a writ of certiorari to the Supreme Court. ${ }^{55}$ In 1994, Congress extended FISC's authority to include ex parte orders for physical search. ${ }^{56}$ In 1998, it incorporated mechanisms for pen register/trap and trace (PR/TT), as well as acquiring business records. ${ }^{57}$ These laws are colloquially referred to as "Traditional FISA." Under them, FISC initially functioned as a warrant-granting body, issuing more than 14,000 orders and just one opinion between 1978 and 2001. ${ }^{58}$ Applications were sealed and procedures conducted in camera and ex parte. ${ }^{59}$

In 2001, the USA PATRIOT Act made numerous changes to FISA. ${ }^{60}$ Although it retained the size of FISCR at three judges, it expanded the number of FISC judges to 11 , of whom at least three must reside within 20 miles of the District of Columbia. ${ }^{61}$ Congress expanded the business records provision to give the Court jurisdiction over orders to require "the production of any tangible things (including books, records, papers, documents, and other items)." ${ }^{62}$ Whereas before records could be sought only from common carriers, public accommodation facilities, storage facilities, and vehicle rental facilities, records now can be sought from any business or entity ${ }^{63}$ In 2005 , when section 215 was set to expire, Congress added language requiring that the government establish "reasonable grounds to believe that the tangible things sought are relevant to

v. Cavanaugh, 807 F.2d 787, 791-92 (9th Cir. 1987); In re Kevork, 634 F. Supp. 1002, 1014 (C.D. Cal. 1985), aff'd, 788 F.2d 566 (9th Cir. 1986).

${ }^{52}$ Foreign Intelligence Surveillance Act of $1978 \S 103(\mathrm{a}), 92$ Stat. at 1788.

5350 U.S.C.A. $\$ 1805$ (a); 124 CONG. REC. 35,389 (1978) (statement of Sen. Mathias).

5450 U.S.C.A. $\$ 1803($ b)

${ }^{55} \mathrm{Id}$. An electronic communication service provider receiving a directive under Title VII of the Foreign Intelligence Surveillance Act may similarly seek certiorari in the Supreme Court. Id. $\$ 1881 \mathrm{a}(\mathrm{i})(6)(\mathrm{B})$.

${ }^{56}$ Intelligence Authorization Act for Fiscal Year 1995, Pub L. No. 103-359, § 302(c), 108 Stat. 3423, 3445 (1994) (codified as amended at 50 U.S.C.A. $\S \$ 1822(\mathrm{c})$ ).

${ }^{57}$ Intelligence Authorization Act for Fiscal Year 1999, Pub. L. No. 105-272, §§ 601-02, 112 Stat. 2396, 2404-12 (1998) (codified as amended at 50 U.S.C.A. $\S \S 1841-1846,1861-1864$ ).

${ }^{58}$ See FISA Annual Reports to Congress, 1979-2002, Foreign Intelligence Surveillance Act, FED'N AM. SCIENTISTS, https://fas.org/irp/agency/doj/fisa/ (July 28, 2020); In re Application of the U.S. for an Ord. Authorizing the Physical Search of Nonresidential Premises \& Pers. Prop., GID.C.00001 (FISC Ct. June 11, 1981), reprinted in S. REP. No. 97-280, at 16-19 (1981).

${ }^{59}$ In re Motion for Release of Ct. Recs., 526 F. Supp. 2d 484, 488 \& n.12, GID.C.00021, at 6 \& n.12 (FISA Ct. 2007).

${ }^{60}$ Uniting and Strengthening America by Providing Appropriate Tools Required to Intercept and Obstruct Terrorism (USA PATRIOT ACT) Act of 2001, Pub. L. No. 107-56, 115 Stat. 272. See, e.g., id. $\S \S 206-208,214-215,218,504,1003,115$ Stat. at 282-83, 286-88, 291, 364-65, 392.

${ }^{61} I d . \S 208,115$ Stat. at 283 .

${ }^{62}$ Id. $\$ 215,115$ Stat. at 287.

${ }^{63}$ Compare id. with Intelligence Authorization Act for Fiscal Year 1999, Pub. L. No. 105-272, § 602, 112 Stat. 2396, 2411 (1998). 
an authorized investigation (other than a threat assessment)" prior to FISC granting an order. $^{64}$

In 2008, Congress further expanded the courts' responsibilities, giving FISC/FISCR oversight over the domestic collection of the communications of non-U.S. persons, as well as U.S. persons, believed to be overseas. ${ }^{65}$ These changes, which entailed oversight of acquisition, minimization, retention, and use of the information obtained, heralded a significant shift in the court's role: so-called "Modernized FISA" ushered in an era of bulk and programmatic collection of citizens' and non-U.S. persons' data. ${ }^{66}$ In light of new technologies, the government sought novel statutory and doctrinal interpretations, forcing the FISC/FISCR to consider constitutional and statutory limits and whether government action comported with the law. ${ }^{67}$

Beset by difficult questions, the courts' roles have altered. ${ }^{68}$ Instead of just issuing orders, the FISC/FISCR now routinely rule on critically-important First, Fourth, and Fifth Amendment questions. ${ }^{69}$ Their decisions impact separation of powers, common

\footnotetext{
${ }^{64}$ USA PATRIOT Improvement and Reauthorization Act of 2005, Pub. L. No. 109-177, § 106, 120 Stat. 192, 196 (codified as amended at 50 U.S.C.A. $\$ 1861$ ).

${ }^{65}$ FISA Amendments Act of 2008, Pub. L. No. 110-261, sec. 101, §§ 702-704, 122 Stat. 2436, 2438-57.

${ }^{66}$ See, e.g., Laura K. Donohue, Bulk Metadata Collection: Statutory and Constitutional Considerations, 37 HaRV. J.L. \& Pub. Pol'y 757 (2014); Laura K. Donohue, Section 702 and the Collection of International Telephone and Internet Content, 38 HARV. J.L. \& PUB. POL'Y 117 (2015); Laura K. Donohue, The Case for Reforming Section 702 of U.S. Foreign Intelligence Surveillance Law, CounCIL ON FOREIGN REL. (June 26, 2017), https://www.cfr.org/report/case-reforming-section-702-us-foreignintelligence-surveillance-law.

${ }^{67}$ As Presiding Judge John Bates explained on one such occasion, "The current application relies on [the] prior framework, but also seeks to expand authorization in ways that test the limits of what the applicable FISA provisions will bear." Memorandum Opinion, [REDACTED], No. PR/TT [REDACTED], GID.C.00092, at 4 (FISA Ct.) (Bates, J.) [hereinafter Bates Mem. Op.]; see also Opinion and Order, [REDACTED], No. PR/TT [REDACTED], GID.C.00091, at 1-2 (FISA Ct.) (Kollar-Kotelly, J.) ("This application seeks authority for a much broader type of collection than other pen register/trap and trace applications."); Order, In re [REDACTED], No. [REDACTED], GID.C.00016, at 12 \& n.5 (FISA Ct. May 31, 2007) (Vinson, J.) (arguing for collection not just to or from but also about a selector); Order and Memorandum Opinion, In re [REDACTED], No. [REDACTED], GID.C.00012, at 16 (FISA Ct. Apr. 3, 2007) (Vinson, J.) (arguing an expanded understanding of "facility" and stating that the NSA makes the probable cause finding for selectors); Primary Order, [REDACTED], No. PR/TT [REDACTED], GID.C.00038 (FISA Ct.) (Walton, J.) (seeking bulk production of Internet metadata using PR/TT); Supplemental Opinion and Amendment to Primary Order, [REDACTED], No. [REDACTED], GID.C.00136, at 3-4 (FISA Ct.) (Bates, J.) ("Under the expansive interpretation of the relevant statutory provisions put forward by the government, the limitations may not have been warranted. But after careful consideration, the Court adopted a less expansive interpretation of the statute.")

${ }^{68}$ See, e.g., USA PATRIOT Act $\S \S 206,208,214-215,218,504,1003,115$ Stat. at 282, 283, 286-88, 291, 364-65, 392; USA PATRIOT Improvement and Reauthorization Act of 2005, § 106, Pub. L. No. 109-177, 120 Stat. 192, 196 (2006); Protect America Act of 2007, Pub. L. No. 110-55, 121 Stat. 552; FISA Amendments Act of 2008, Pub. L. No. 110-261, 122 Stat. 2436; see also In re Directives to Yahoo!, Inc. Pursuant to Section 105B of the Foreign Intel. Surveillance Act, No. 105B (g): 07-01, GID.C.00025, at 3 (FISA Ct. Apr. 25, 2008) (Walton, J.) (noting "the [Protect America Act of 2007] . . . is hardly a model of legislative clarity or precision."); Supplemental Opinion, In re Prod. of Tangible Things from [REDACTED], No. BR 08-13, GID.C.00033, at 2-3 (FISA Ct. Dec. 12, 2008) (Walton, J.) (addressing tension between 50 U.S.C.A. $\$ 1861$ and 18 U.S.C.A. $\$ \S 2702-2703$ ).

${ }^{69} \mathrm{See}$, e.g., Order and Memorandum Opinion, In re Proc. Required by Section 702(i) of the FISA Amends. Act of 2008, No. Misc 08-01, GID.C.00028, 2008 WL 9487946 (FISA Ct. Aug. 27, 2008) (McLaughlin, J.) (First and Fourth Amendments); Opinion on Motion for Disclosure of Prior Decisions, [REDACTED], No. [REDACTED], GID.C.00112 (FISA Ct. 2014) (Collyer, J.) (Fifth Amendment); Memorandum, In re Application of the FBI for an Ord. Requiring Prod. of Tangible Things from [REDACTED], No. BR 13-158, GID.C.00086 (FISA Ct. Oct. 11, 2013) (McLaughlin, J.) (First and
} 
law, and the rule of law. The Court examines complex matters of statutory construction. ${ }^{70}$ And it monitors how the government wields its power. ${ }^{71}$ FISC/FISCR opinions reveal the extent to which government actions comport with - or violatecourt directions and the law. ${ }^{72}$

An important and robust body of law is now emerging from a court that, for decades, has been largely shielded from public inspection. ${ }^{73}$ Nearly 100 declassified FISC/FISCR opinions and 300 orders are now in the public domain, as are hundreds of FISC/FISCR filings. Non-specialized Article III courts, moreover, are increasingly having to grapple with FISA and to integrate FISC jurisprudence into their decisions.

\section{Alien Terrorist Removal Court}

In 1987, the Immigration and Naturalization Service initiated what would become a 20-year effort to deport seven Palestinian men and a Kenyan woman suspected of being members of the Popular Front for the Liberation of Palestine, a radical wing of the Palestine Liberation Organization. ${ }^{74}$ The L.A. Eight became emblematic of the difficulties entailed in using classified evidence in deportation cases ${ }^{75}$ In response, the Reagan Administration proposed the creation of a special court to handle classified evidence and removal of aliens. ${ }^{76}$ Similar to the FISC/FISCR, the new court would be

Fourth Amendments); In re Sealed Case, 310 F.3d717, GID.CA.00001 (FISA Ct. 2002) (Fourth Amendment).

${ }^{70}$ See, e.g., Supplemental Opinion, In re Prod. of Tangible Things, No. BR 08-13, GID.C.00033.

${ }^{71}$ Memorandum Opinion and Order, [REDACTED], No. [REDACTED], GID.C.00050, at 10-11 (FISA Ct. 2009) (Hogan, J.).

${ }^{72}$ See, e.g., Supplemental Opinion and Order, In re Application of the FBI for an Ord. Requiring the Prod. of Tangible Things [REDACTED], No. BR 09-15, GID.C.00048, at 3-4 (FISA Ct. Nov. 5, 2009) (Walton, J.) (NSA sent query results to email list of 189 analysts, "only 53 of whom had received the required training”); Memorandum Opinion, [REDACTED], No. [REDACTED], GID.C.00073, at 15-18, 78-80 (FISA Ct. Oct. 3, 2011) (Bates, J.) (NSA misled Court, violating FISA and the Fourth

Amendment); Bates Mem. Op., GID.C.00092, at 3, 18, 100-105 ("NSA exceeded the scope of authorized acquisition continuously during the more than [REDACTED] years of acquisition"; FBI, CIA, and NCTC "accessed unminimized U.S. person information"; NSA disseminated "reports containing U.S. person information"; government requested permission to violate law); Memorandum Opinion, [REDACTED], No. [REDACTED], GID.C.00078, at 26-27 (FISA Ct. Sept. 25, 2012) (NSA misrepresented upstream collection, acquiring U.S. person domestic communications).

${ }^{73}$ More than two decades after its 1981 opinion, the Court issued two opinions. In re Sealed Case, 310 F.3d 717, GID.CA.00001 (FISA Ct. Rev. 2002); In re All Matters Submitted to Foreign Intel. Surveillance Ct., 218 F. Supp. 2d 611, GID.C.00002 (FISA Ct. 2002), abrogated by In re Sealed Case, 310 F.3d 717, GID.CA.00001. It published two more opinions between 2007 and 2008. In re Directives [REDACTED] Pursuant to Section 105B of Foreign Intel. Surveillance Act, 551 F.3d 1004, GID.CA.00002 (FISA Ct. Rev. 2008); In re Motion for Release of Ct. Recs., 526 F. Supp. 2d 484, GID.C.00021 (FISA Ct. 2007).

${ }^{74}$ Henry Weinstein, Final Two L.A. Defendants Cleared, L.A. Times (Nov. 1, 2007), https://www.latimes.com/archives/la-xpm-2007-nov-01-me-palestinian1-story.html.

75 The immigrants in that case had been distributing Al Hadaf, the Popular Front's magazine, which was also available in public libraries and the U.S. Library of Congress. Id. Initially charged under the McCarthy-era McCarran-Walter Act (which had not been used since the 1950s), six of the non-U.S. residents quickly had the charges dropped against them, with technical visa violations alleged in their place. Phyllis Bennis, Ten Years of the Los Angeles Eight Deportation Case: Interview with David Cole, MidDLE E. REP., Winter 1997, at 41, 41; Immigration and Nationality Act of 1952, Pub. L. No. 82-414, 66 Stat. 163. The two permanent U.S. residents were then charged with associating with an organization advocating the destruction of property. Bennis, supra note 75.

${ }^{76}$ Steven R. Valentine, Flaws Undermine Use of Alien Terrorist Removal Court, LEGAl BACKGROUNDER (Wash. Legal Found., Wash., D.C.), Feb. 22, 2002, at 1, 1, https://s3.us-east2.amazonaws.com/washlegal-uploads/upload/022202LBValentine.pdf (although the claim is not 
comprised of sitting U.S. District Court judges selected by the Chief Justice. ${ }^{77}$ It was not until the bombing of the Alfred P. Murrah Federal Building in Oklahoma City, however, and passage of the 1996 Anti-terrorism and Effective Death Penalty Act, that Congress created the specialized Article III court. ${ }^{78}$ Later in the year, further revisions allowed for removal proceedings to proceed even where the court deemed the proposed unclassified summary inadequate. ${ }^{79}$

The Alien Terrorist Removal Court (ATRC) consists of 5 district court judges appointed by the Chief Justice from 5 of the U.S. judicial circuits ${ }^{80}$ Currently, four of the five federal judges currently on the court are also members of the FISC. ${ }^{81}$ The judges serve five year terms, are eligible for re-designation, and may be jointly appointed to the FISC/FISCR. ${ }^{82}$ The court's decisions are reviewable by the U.S. Court of Appeals for the District of Columbia and eligible for a writ of certiorari to the Supreme Court. ${ }^{83}$ The Attorney General or Deputy Attorney General must certify the application with a statement of the facts and circumstances relied on by the DOJ to establish probable cause that an alien is an "alien terrorist" (as described in 8 U.S.C.A. § 1227(a)(4)(B)) and physically present in the United States, and removal under the regular immigration provisions would pose a risk to national security ${ }^{84}$ Where these conditions are met, the judge is required to issue an order granting the application. ${ }^{85}$ Denial must be accompanied by a written statement of the reasons. ${ }^{86}$

Although the measures have been in place for nearly a quarter of a century, the Attorney General has never applied to the ATRC to remove an alien terrorist, with the result that the court has never conducted a proceeding. ${ }^{87}$ One theory as to why this is the case highlights built-in procedural flaws: namely, that there is no other "recourse to remove [lawful permanent residents] against whom the sole evidence of their terrorist identity is FISA-obtained or derived from foreign intelligence information or is not

footnoted in the article, the author served from 1988 to 1993 in the Reagan and Bush Administrations as the Deputy Assistant Attorney General in charge of the Office of Immigration Litigation in the U.S. Department of Justice Civil Division).

${ }^{77} I d$. at 2.

${ }^{78}$ Congress refused to hold hearings. See id. Following the 1993 World Trade Center bombing, Senator Robert Smith (R-N.H.) proposed an amendment to the 1994 crime bill to establish the terrorist removal court. Although a voice vote carried it, during the Senate Conference, the provision was dropped. Id. The following year, Smith re-introduced it as a standalone bill. See Alien Terrorist Removal Act of 1995, S. 270, 104th Cong. (1995). Senator Joe Biden (D-Del.), on behalf of the Clinton Administration, similarly introduced the Omnibus Counterterrorism bill, a bipartisan bill. Omnibus Counterterrorism Act of 1995, S. 390, 104th Cong. (1995). See also Antiterrorism and Effective Death Penalty Act of 1996, Pub. L. No. 104-132, sec. 401, $\S 501-507,110$ Stat. 1214, 1258-68 (codified as amended at 8 U.S.C.A. $\S \S 1531$ 1537 (West)).

${ }^{79}$ Omnibus Consolidated Appropriations Act of 1997, Pub. L. No. 104-208, § 354, 110 Stat. 3009, 3009641 to 3009-644 (1996).

808 U.S.C.A. $\$ 1532$ (a).

${ }^{81}$ See Alien Terrorist Removal Courts: Judges, FED. JUD. CTR., https://www.fjc.gov/history/courts/alienterrorist-removal-court-judges (last visited Dec. 31, 2020); Current Membership - Foreign Intelligence Surveillance Court, U.S. FOREIGN INTEL. SURVEILLANCE CT., https://www.fisc.uscourts.gov/currentmembership (last visited Dec. 31, 2020).

828 U.S.C.A. $§ 1532(a)-(b)$.

${ }^{83}$ Id. $\S 1535$.

${ }^{84} I d . \S 1533(\mathrm{a})(1)(\mathrm{D})$.

${ }^{85} I d . \S 1533(\mathrm{c})(2)$.

${ }^{86}$ Id. $\$ 1533(\mathrm{c})(3)$.

${ }^{87}$ Alien Terrorist Removal Court, 1996-Present, FED. JUD. CTR., https://www.fjc.gov/history/courts/alienterrorist-removal-court-1996-present (last visited Oct. 18, 2020) (current as of 2018). 
appropriate for declassification or public acknowledgement." ${ }^{88}$ While the statute authorizes the use of FISA-derived information in the proceedings, where the court does not approve of the government's proposed unclassified summary of key evidence, the court has to find two conditions: "(I) the continued presence of the alien in the United States would likely cause serious and irreparable harm to the national security or death or serious bodily injury to any person, and (II) the provision of the summary would likely cause serious and irreparable harm to the national security or death or serious bodily injury to any person." ${ }^{\prime 9}$ Because the court must make both findings, the government is left in the "same type of 'Catch-22' dilemma that justified the ATRC's creation" in the first place: i.e., "disclosing and risking sources and methods . . . versus the removal alien terrorists." 90

\section{U.S. Court of Appeals for the Federal Circuit ${ }^{91}$}

Historically, federal district courts had exclusive jurisdiction over cases related to federal patent law and copyrights. ${ }^{92}$ In the late 1970s and early 1980 s though, corporations, government attorneys, and academics convinced Congress that creating a single appellate court for patent cases would help to create consistency and to relieve the pressure on district courts for cases involving complex litigation and detailed technical expertise. ${ }^{93}$ In 1982, Congress responded by creating the U.S. Court of Appeals for the Federal Circuit, merging the U.S. Court of Customs and Patent Appeals and the appellate division of the U.S. Court of Claims. ${ }^{94}$ It consists of twelve judges appointed by the President, by and with the consent of the Senate. ${ }^{95}$

The Court has exclusive jurisdiction over appeals in cases in which the district court's jurisdiction was based on 28 U.S.C.A. $§ 1338$. This includes: (a) civil actions related to patents or plant variety protection; (b) certain appeals of claims against the United States (c) appeals from the U.S. Court of Federal Claims; (d) appeals from decisions of the U.S. Patent and Trademark Office or the U.S. Court of International Trade; and (e) review of certain agency decisions and appeals linked to particular statutory authorities (e.g., $\S 211$ of the 1970 Economic Stabilization Act, $\S 5$ of the 1973 Emergency Petroleum Allocation Act, and § 506(c) of the Natural Gas Policy Act). ${ }^{96}$ The court also has jurisdiction over interlocutory decisions. ${ }^{97}$ Accordingly, one scholar has proposed that the D.C. and Federal Circuits are more properly considered "semi-

\footnotetext{
${ }^{88}$ Aram A. Gavoor \& Timothy M. Belsan, The Forgotten FISA Court: Exploring the Inactivity of the ATRC, 81 OHIO ST. L.J. 139, 141-42 (2020).

898 U.S.C.A. $§ 1534(\mathrm{e})(3)(\mathrm{D})(\mathrm{iii})$.

${ }^{90}$ Gavoor \& Belsan, supra note 88, at 142 .

${ }^{91}$ The Court of Claims, one of the precursors to the Federal Circuit, is discussed infra text accompanying notes 129-135. Further related history can be found infra Part III.C. discussing the U.S. Court of Federal Claims.

9228 U.S.C.A. $\$ 1338$.

${ }^{3}$ See Rochelle C. Dreyfuss, The Federal Circuit: A Case Study in Specialized Courts, 64 NYU L. REV. 1, 1-2, 6-7 (1989).

${ }^{94}$ See Federal Courts Improvement Act of 1982, Pub. L. No. 97-164, 96 Stat. 25.

9528 U.S.C.A. $\S 44$.

${ }^{96} I d$. $\S 1295$. The court does not have exclusive jurisdiction over the inhabited territorial courts (i.e., Guam, the Virgin Islands and the North Mariana Islands, with the exception of matters related to the subjects listed.

${ }^{97} I d . \S 1292$.
} 
specialized," as significant portions of their dockets deal with issues outside narrow categories such as administrative and patent law. ${ }^{98}$

The court operates under a modified version of the Federal Rules of Appellate Procedure, referred to as the U.S. Court of Appeals for the Federal Circuit Rules of Practice. ${ }^{99}$ Although initially the Supreme Court allowed the Federal Circuit court to operate fairly freely, in recent years it has begun to take a stronger stand, reversing a number of the court's decisions on substantive grounds. ${ }^{100}$ In 2017 , for instance, the Supreme Court granted certiorari in seven cases, six of which it reversed in whole or part. ${ }^{101}$

\section{U.S. Court of International Trade}

The U.S. Court of International Trade has exclusive jurisdiction over any civil actions arising under certain sections of the 1930 Tariff Act, 1974 Trade Act, and the 1979 Trade Agreements Act; rulings issued by the Secretary of the Treasury related to certain decisions impacting trade; any law providing for revenue from imports or tonnage, tariffs, duties, fees, or other taxes on imports; and restrictions on imports. ${ }^{102}$ Congress created it in 1980 to reorganize the predecessor Customs Court. It consists of nine judges (not more than 5 of whom can be from the same political party-a requirement that raises constitutional concerns), appointed by the President by and with the advice and consent of the Senate. ${ }^{103}$ The court, which is located in New York, possesses "all the powers in law and equity of, or as conferred by statute upon, a district court of the United States." 104

\section{Specialized Courts No Longer in Existence}

\footnotetext{
${ }^{98}$ John M. Golden, The Federal Circuit and the D.C. Circuit: Comparative Trials of Two SemiSpecialized Courts, 78 GEO. WASH. L. Rev 553, 553-55 (2010).

${ }^{99}$ FED. CIR. R. (July 1, 2020), http://www.cafc.uscourts.gov/sites/default/files/rules-ofpractice/FederalCircuitRulesofPractice-July2020.pdf.

${ }^{100}$ See, e.g., Teva Pharm. USA, Inc. v. Sandoz, Inc., 574 U.S. 318, 322 (2015) (reversing the circuit's practice of considering findings of fact de novo); eBay, Inc. v. MercExchange, L.L.C., 547 U.S. 388, 393-94 (2006) (rejecting a Federal Circuit application of a "general rule" unique to patent disputes instead of using the traditional four-factor test for granting a permanent injunction).

${ }^{101}$ See Sandoz Inc. v. Amgen Inc., 137 S. Ct. 1664 (2017) (consolidating Nos. 15-1039, 15-1195)

(focused on requirements under the Biologics Price Competition and Innovation Act of 2009 to provide sponsor with a copy of the biologics license application and the sponsor's recourse for failure to provide that information); Impression Prods., Inc. v. Lexmark Int'1, Inc., 137 S. Ct. 1523 (2017) (patent exhaustion due to conditional and authorized sales); Matal v. Tam, 137 S. Ct. 1744 (2017), aff'g In re Tam, 808 F.3d 1321 (Fed. Cir. 2015) (en banc) (constitutionality of disparaging marks provision of the Lanham Act); Life Techs. Corp. v. Promega Corp., 137 S. Ct. 734 (2017) (infringement liability for worldwide sales under 35 U.S.C. § 271(f)(1) for supplying a single commodity component); SCA Hygiene Prods. Aktiebolag v. First Quality Baby Prods., LLC, 137 S. Ct. 954 (2017) (availability of laches in patent infringement actions); TC Heartland LLC v. Kraft Foods Grp. Brands LLC, 137 S. Ct. 1514 (2017) (patent venue).

10228 U.S.C.A. § 1581. It also has exclusive jurisdiction over civil actions related to import commenced by the United States, related counter-, cross-, and third-party claims, and civil actions under the United States-Mexico-Canada Agreement (USMCA) or the U.S.-Canada Free Trade Agreement. Id. $\S \S 1582-$ 1584.

${ }^{103}$ Customs Courts Act of 1980, Pub. L. No. 96-417, § 101, 94 Stat. 1727, 1727 (codified as amended at 28 U.S.C.A. § 251).

10428 U.S.C.A. $§ 1585$.
} 
At least seven specialized Article III courts created by Congress no longer exist. The first, the United States Customs Court, appears to have been an Article III court based on the statute designating it as such in $1956 .{ }^{105}$ In 1980, the Customs Court was replaced by the U.S. Court of International Trade. ${ }^{106}$

From 1909 to 1929, appeals from the Customs Court (and its predecessor Board of U.S. General Appraisers) were made to the Court of Customs Appeals, an article I tribunal. ${ }^{107}$ In 1929, Congress expanded jurisdiction to include patent and trademark and changed the court's name to the Court of Customs and Patent Appeals. ${ }^{108} 29$ years later, Congress formally designated the court as established under Article III. ${ }^{109}$ In 1982, this court's functions were subsumed by the then newly created U.S. Court of Appeals for the Federal Circuit. ${ }^{110}$

During World War II, Congress passed the Emergency Price Control Act of 1942 to stabilize prices and prevent profiteering. ${ }^{111}$ It created the Emergency Court of Appeals, comprised of three or more district or circuit judges selected by the Chief Justice, with exclusive jurisdiction over challenges to regulations issued by the Office of Price Administration. ${ }^{112}$ The statute empowered the chief judge (selected by the Chief Justice) to divide the court into divisions of three or more judges to render judgment. The court was granted "the powers of a district court with respect to the jurisdiction conferred on it," except the court was explicitly denied the authority "to issue any temporary restraining order or interlocutory decree staying or restraining, in whole or in part, the effectiveness" of certain regulations or orders. ${ }^{113}$ A petition for a writ of certiorari could be filed in the Supreme Court within thirty days of a judgment or order by the court. ${ }^{114}$ Although the court was created as part of a temporary measure, Congress repeatedly renewed the authority, expanding its jurisdiction to include review of agency decisions under the Housing and Rent Acts of 1948 and 1949 as well as Defense Production Act. ${ }^{115}$ In 1961, the court heard its final case. It formally dissolved April 18, $1962 .{ }^{116}$

In 1971, Congress created a Temporary Emergency Court of Appeals, again consisting of three or more judges to be designated by the Chief Justice from the judges of the district courts and circuit courts of appeals. ${ }^{117}$ Like the prior court, the temporary

\footnotetext{
${ }^{105}$ Act of July 14, 1956, Pub. L. No. 84-703, 70 Stat. 532. Prior to that time, the U.S. Customs Court was considered a legislative court. See Ex parte Bakelite Corp., 279 U.S. 438, 457-58 (1929).

${ }^{106}$ Customs Courts Act of 1980, Pub. L. No. 96-417, § 101, 94 Stat. 1727, 1727 (codified as amended at 28 U.S.C.A. § 251).

${ }^{107}$ See Act of Aug. 5, 1909, ch. 6, § 29, 36 Stat. 11, 105; Bakelite Corp., 279 U.S. at 457-58.

108 Act of Mar. 2, 1929, ch. 488, § 1, 45 Stat. 1475, 1475.

${ }^{109}$ Act of Aug. 25, 1958, Pub. L. No. 85-755, § 1, 72 Stat. 848, 848.

110 See Federal Courts Improvement Act of 1982, Pub. L. No. 97-164, 96 Stat. 25.

${ }^{111}$ Emergency Price Control Act of 1942, ch. 26, § 204, 56 Stat. 23, 31.

${ }^{112}$ See id. $\S \S 204(\mathrm{a})-(\mathrm{c}), 201,56$ Stat. at 31-32, 29.

${ }^{113} I d . \S 204(\mathrm{c}), 56$ Stat. at 32.

${ }^{114} I d . \$ 204(\mathrm{~d}), 56$ Stat. at 32.

115 See Housing and Rent Act of 1948, ch. 161, sec. 202(d), § 204(e)(4), 62 Stat. 93, 96; Housing and Rent Act of 1949, ch. 42, sec. 203(d)(5), (e), § 204(e)(1), (e)(4)(E), 63 Stat. 18, 23-24; Defense Production Act of 1950, ch. 932, §§ 407(d), 408, 64 Stat. 798, 808-11; see also Emergency Court of Appeals, 1942-1962, FED. JUD. CTR., https://www.fjc.gov/history/courts/emergency-court-appeals-19421962 (last visited Oct. 20, 2020).

116 See Emergency Court of Appeals, supra note 115.

${ }^{117}$ Economic Stabilization Act Amendments of 1971, Pub. L. No. 92-210, sec. 2, § 211(b), 85 Stat. 743 , 749.
} 
one, which operated until 1993, ${ }^{118}$ served as an Article III court. ${ }^{119}$ Congress provided it with circuit court powers relating to wage and price control programs, with some exceptions. ${ }^{120}$

The controversial (and short-lived) Commerce Court (1910-1913) acted as an Article III court as well. ${ }^{121}$ Largely a pet project of President William Howard Taft, the Court had exclusive jurisdiction over challenges to orders issued by the Interstate Commerce Commission (ICC). Appeal was via a writ of certiorari to the Supreme Court. The Court consisted of five judges appointed for overlapping five-year terms. ${ }^{122}$ Upon their appointment, the first round of judges simultaneously received appointments to different circuit courts of appeal, where they could hear cases as needed. At the conclusion of their term, they continued to sit on the circuit court to which they had been appointed, with replacements drawn from individuals already appointed to the federal bench. Congress provided the Commerce Court with full powers of a circuit court in regard to cases within its jurisdiction as well as the ability to "issue all writs and process appropriate." 123 The first Chief Judge of the Court, Martin Knapp, had previously served as chair of the ICC. He had a clear interest in keeping what he perceived of as industrial control of the ICC in check. In reflection of this position, the court went on to overturn a number of ICC decisions, which the Supreme Court subsequently restored. ${ }^{124}$ Judge Robert W. Archbald's impeachment in July 1912 for using his position to secure railroad contracts for his cronies generated renewed Congressional effort to abolish the court. Taft, however, vetoed the bill. Nevertheless, the following year, with President Woodrow Wilson's support, Congress eliminated the tribunal. ${ }^{125}$

In the early 1970s, a number of railways in the midwest and northeast of the United States filed for bankruptcy. Congress responded by passing the 1974 Regional Rail Reorganization Act. ${ }^{126}$ The statute reorganized railroads into an economically viable system, established the U.S. Railway Association and the Consolidated Rail Corporation, and provided assistance to states and local and regional transportation authorities to promote rail travel. It also established a special court, composed of three federal judges assigned by the Judicial Panel on Multidistrict Litigation. ${ }^{127}$ The judges were given the authority to exercise the powers of district court judges. In 1996, Congress provided for the abolition of the Court under the Federal Courts Improvement Act. ${ }^{128}$

\footnotetext{
${ }^{118}$ Federal Courts Administration Act of 1992, Pub. L. No. 102-572, § 102(d), 106 Stat. 4506, 4507.

${ }^{119}$ See, e.g., Lockerty v. Phillips, 319 U.S. 182, 187-88 (1943); In re Coordinated Pretrial Proc. in Petroleum Antitrust Litig., M.D.L. 150, 830 F.2d 198, 202-04 (Temp. Emer. Ct. App. 1987), Halleck v. Berliner, 427 F. Supp. 1225, 1251 (D.D.C. 1977).

${ }^{120}$ Economic Stabilization Act Amendments of $1971 \S 211,85$ Stat. at 748-50; Spinetti v. Atl. Richfield Co., 522 F.2d 1401, 1403.

${ }^{121}$ Act of June 18, 1910, ch. 309, § 1, 36 Stat. 539, 539.

${ }^{122} I d$. at 540.

${ }^{123} \mathrm{Id}$. at 541 .

${ }^{124}$ In four of the Court's first five cases, it reversed ICC orders, and in each instance, the Supreme Court restored the original ICC order. Dan Ernst, The U.S. Commerce Court, 1910-1913, LEGAL Hist. BLOG

(May 19, 2015), http://legalhistoryblog.blogspot.com/2015/05/the-us-commerce-court-1910-1913.html.

125 Act of Oct. 22, 1913, ch. 32, 38 Stat. 208, 219.

${ }^{126}$ Regional Rail Reorganization Act of 1973, Pub. L. No. 93-236, 87 Stat. 985 (1974).

127 Id. § 209(b), 87 Stat. at 999-1000.

${ }^{128}$ Federal Courts Improvement Act of 1996, § 605, 110 Stat. 3847, 3858.
} 
The Court of Claims, established in 1855, initially operated as an administrative body and, later, as an Article I tribunal. ${ }^{129}$ The originating statute directed the court to hear and determine claims against the U.S. government, as well as claims referred to the court by either the Senate or the House of Representatives. ${ }^{130}$ In 1863, Congress authorized the court to render final judgments, from which an appeal could follow under certain circumstances. ${ }^{131}$ In 1953, Congress declared that the Court of Claims was an Article III court. ${ }^{132}$ Nine years later, the Supreme Court confirmed the court's status (along with the Courts of Customs and Patent Appeals), noting that because the judges were constitutionally protected in regard to their tenure of office and undiminished compensation, they were eligible to sit as Court of Appeals and U.S. District Court judges. ${ }^{133}$ In 1982, however, Congress turned the tribunal back into an Article I Court. ${ }^{134}$ It continues to operate as such, subject to review in the (Article III) U.S. Court of Appeals for the Federal Circuit. ${ }^{135}$

\section{Inherent Powers Central to Article III(1) Courts}

The inherent powers of all Article III(1) courts are rooted in their constitutional responsibility to administer justice and their status as the third branch of government. ${ }^{136}$ They divide into inherent powers that (1) ensure the judiciary can fulfill its obligation to ensure fairness in the course of adjudication; (2) facilitate the efficient use of judicial resources; and (3) protect the integrity, independence, and reputation of the courts. Within each category, powers that go to the core of the courts operating in their constitutional capacity (i.e., in the exercise of "the judicial power") are considered essential and thus beyond the reach of the other two branches. They are part and parcel of the separation of powers that marks the federal system. Such authorities can be distinguished from inherent powers that are merely beneficial, in which case Congress may have some role to play in their demarcation. ${ }^{137}$

\section{Ensure Fairness and Justice in the Course of Adjudication}

Federal courts have certain inherent powers that enable them to fulfill their substantive responsibility to ensure fairness and justice in the course of adjudication. While Congress may act to facilitate the overall objective, certain authorities do not rely on any legislative framing. To obtain equitable results, for instance, courts must be able to obtain accurate facts. By extending their purview to cases in equity, Article III(2) provides an underlying authority to do this - a power further recognized (but not solely constructed) by Congress in the first Judiciary Act. ${ }^{138}$ Accordingly, Article III(1) courts

\footnotetext{
${ }^{129}$ Act of Feb. 24, 1855, ch. 122, § 1, 10 Stat. 612, 612. See infra Part III.C. for further discussion of the Court of Claims and U.S. Court of Federal Claims.

13010 Stat. at 612.

131 Act of Mar. 3, 1863, ch. 92, §§ 3, 5, 12 Stat. 765, 765, 766.

132 Act of July 28, 1953, Pub. L. No. 83-158, 67 Stat. 226.

133 Glidden Co. v. Zdanok, 370 U.S. 530, 569-71 (1962) (Harlan, J., plurality opinion).

${ }^{134}$ Federal Courts Improvement Act of 1982, Pub. L. No. 97-164, sec. 105, § 171, 96 Stat. 25, 27 (codified as amended at 28 U.S.C.A. § 171 (West)); see also Williams v. United States, 289 U.S. 553, 581 (1933).

13528 U.S.C.A. $\S \S 171$ (a), 1295(a)(3); see also Federal Courts Administration Act of 1992, Pub. L. No. 102-572, § 902(a), 106 Stat. 4506, 4516 (assigning the name "United States Court of Federal Claims").

${ }^{136}$ See, e.g., In re Peterson, 253 U.S. 300, 312 (1920) Michaelson v. United States ex. rel. Chicago, St. P., M. \& O. Ry. Co., 266 U.S. 42, 65-66 (1924); In re Stone, 986 F.2d 898, 902 (5th Cir. 1993).

${ }^{137}$ See supra note 9.

${ }^{138}$ See Judiciary Act of 1789, ch. 20, § 19, 1 Stat. 73, 83.
} 
can appoint auditors, special masters, and commissioners to make investigations. ${ }^{139}$ They can use discovery procedures in habeas cases. ${ }^{140}$ Article III judges can allow posttrial depositions. ${ }^{141}$ They can require the production of witness statements and parties to attend hearings regarding missing evidence. ${ }^{142}$ They can make in limine rulings. ${ }^{143}$ Article III entities have inherent authority to exclude, admit, or strike evidence or exhibits on grounds of fairness. ${ }^{144}$ They also have the inherent power to issue and answer letters rogatory to obtain evidence from an individual within the jurisdiction of a foreign court. ${ }^{145}$ This is done as a matter of parity between the judicial functions of internationally-recognized governments. ${ }^{146}$

Pari passu, lower courts have recognized the judiciary's power to ensure that matters of law are addressed. For example, they can require parties to enter memoranda of law. ${ }^{147}$ They can require counsel to serve standby. ${ }^{148}$ They can require parties to retain a lawyer. ${ }^{149}$ They can assign attorneys for pretrial actions. ${ }^{150}$ And they can appoint amici curiae. ${ }^{151}$ For the sake of consistency, courts have the power, derived from common law, to ensure stare decisis as a matter of both horizontal and vertical parity. ${ }^{152}$

The courts have further inherent authorities related to the conduct of trials. They can, for instance, withdraw a juror mid-trial where it would be "a total failure of justice if the trial proceed." 153 They can fine jurors who try to leave without permission. ${ }^{154}$ They can discharge a jury from delivering a verdict. ${ }^{155}$ They can excise jury determinations and order a reduction in an excessive verdict. ${ }^{156}$ Notably, nowhere can

${ }^{139}$ See Peterson, 253 U.S. at 304-07, 312-14 (1920); Ruiz v. Estelle, 679 F.2d 1115, 1161 (5th Cir. 1982), amended in part and vacated in part on other grounds, 688 F.2d 266 (5th Cir. 1982); Schwimmer v. United States, 232 F.2d 855, 865 (8th Cir. 1956); Heckers v. Fowler, 69 U.S. (2 Wall.) 123, 127-29 (1864).

${ }^{140}$ Harris v. Nelson, 394 U.S. 286, 290 (1969).

${ }^{141}$ United States ex rel. Consol. Elec. Distribs., Inc. v. Altech, Inc., 929 F.2d 1089, 1091-92 (5th Cir. 1991).

${ }^{142}$ See Jencks v. United States, 353 U.S. 657, 668-69 (1957); Brockton Sav. Bank v. Peat, Marwick, Mitchell \& Co., 771 F.2d 5, 11-12 (1st Cir. 1985).

${ }^{143}$ Luce v. United States, 469 U.S. 38, 41 n.4 (1984).

${ }^{144}$ Unigard Sec. Ins. Co. v. Lakewood Eng'g \& Mfg. Corp., 982 F.2d 363, 368 (9th Cir. 1992); Walker v. Action Indus., Inc., 802 F.2d 703, 712 (4th Cir. 1986); Admiral Theatre Corp. v. Douglas Theatre Co., 585 F.2d 877, 897-98 (8th Cir. 1978).

${ }^{145}$ In re Letter Rogatory from Just. Ct., Dist. of Montreal, Can., 523 F.2d 562, 564 (6th Cir. 1975) (“[I]t has been held that federal courts have inherent power to issue and respond to letters rogatory.") (citing United States v. Reagan, 453 F.2d 165, 173 (6th Cir. 1971); United States v. Staples, 256 F.2d 290, 292 (9th Cir. 1958); In re Pac. Ry. Comm'n, 32 F. 241, 256-57 (C.C.N.D. Cal. 1887)).

${ }^{146}$ In re Letter Rogatory, 523 F.2d at 563 n.1 (quoting The Signe, 37 F. Supp. 819, 820 (E.D. La. 1941)).

${ }^{147}$ Alameda v. Sec'y of Health, Educ. \& Welfare, 622 F.2d 1044, 1047 (1st Cir. 1980).

148 United States v. Bertoli, 994 F.2d 1002, 1018 (3d Cir. 1993).

${ }^{149}$ See J.D. Pharm. Distribs., Inc. v. Save-On Drugs \& Cosmetics Corp., 893 F.2d 1201, 1208-09 (11th Cir. 1990).

${ }^{150}$ In re Air Crash Disaster at Fla. Everglades on Dec. 29, 1972, 549 F.2d 1006, 1011-12 (5th Cir. 1977).

${ }^{151}$ In re Utils. Power \& Light Corp., 90 F.2d 798, 800 (7th Cir. 1937).

${ }^{152}$ Agostini v. Felton, 521 U.S. 203, 235 (1997).

${ }^{153}$ United States v. Coolidge, 25 F. Cas. 622, 623 (C.C.D. Mass. 1815) (No. 14,858).

${ }^{154}$ Offutt v. Parrott, 18 F. Cas. 606, 607 (C.C.D.C. 1803) (No. 10,453) (fining a juror who jumped out a window to try to escape jury service).

155 United States v. Perez, 22 U.S. (9 Wheat.) 579, 580 (1824).

156 The first recorded use of remittitur was by Justice Joseph Story. See Blunt v. Little, 3 F. Cas. 760, 762 (C.C.D. Mass. 1822) (No. 1578); see also Barrett, supra note 9, at 829. Even though the rules provide for the grant of a new trial, it remains a judicial power. See FED. R. CIV. P. 59. 
remittitur be found in statutory form. ${ }^{157}$ They can rescind a discharge order and recall the jury for further deliberation. ${ }^{158}$ So, too, can they mediate the impact of common law rules of procedure. ${ }^{159}$ These powers are not established by Congress. They are entirely within the courts' authority qua the judicial branch of government.

Article III(1) courts also have the (essential) power to make decisions that are not subject to control by the other branches. When they act in this core judicial capacity, separation of powers prevents the other branches from interfering. To give effect to their determinations, this extends to the ability to control and review their decisions. If it did not, the other branches could simply intervene after the fact effectively nullify judicial decisionmaking by preventing it from reaching the public domain. As a consequence, as the Supreme Court explained in Nixon v. Warner Communications, "Every court has supervisory power over its own records and files." 160 They can seal, unseal, revoke, or rescind orders. ${ }^{161}$ They can modify or lift protective orders. ${ }^{162}$ This power persists even when jurisdiction over the relevant controversy has ended. ${ }^{163}$ Jurisdiction over the sealed record is not lost when the case is appealed. ${ }^{164}$

\section{Facilitate the Efficient Use of Resources}

In 1936, the Supreme Court recognized the inherent authority of the judiciary to manage its affairs with a view toward the efficient and expedient resolution of cases. ${ }^{165}$ In 2017, the Court reiterated its position, noting that the judiciary has the power, conferred by neither rules nor statutes, "to manage their own affairs so as to achieve the orderly and expeditious disposition of cases." 166 While dockets may in many circumstances be mandatory (excepting, for instance, the certiorari process), Article III courts control how that docket is handled. ${ }^{167}$

\footnotetext{
${ }^{157}$ Barrett, supra note 9, at 829. Remittur is constitutionally assigned to the Courts in their Article III(2) grant of equitable authority. In contrast, additur, which is not an equitable remedy, has not been allowed in federal court. See Dimick v. Scheidt, 293 U.S. 474 (1935).

${ }^{158}$ Dietz v. Bouldin, 136 S. Ct. 1885, 1890 (2016).

${ }^{159}$ See Funk v. United States, 290 U.S. 371, 382 (1933).

${ }^{160}$ Nixon v. Warner Commc'ns, 435 U.S. 589,598 (1978). Accord Gambale v. Deutsche Bank AG, 377

F.3d 133, 140-41 (2d Cir. 2004); Brown \& Williamson Tobacco Corp.. v. Federal Trade Comm'n, 710

F.2d 1165, 1177 (6th Cir. 1983).

${ }^{161}$ Marconi Wireless Tel. Co. of Am. v. United States, 320 U.S. 1, 47-48 (1943); United States v. Seugasala, 670 F. App'x 641, 641-42 (9th Cir. 2016) (mem.); United States v. Shryock, 342 F.3d 948, 983 (9th Cir. 2003); United States v. Mann, 829 F.2d 849, 853 (9th Cir. 1987). This includes the authority to revoke orders granting bail. Fernandez v. United States, 81 S. Ct. 642 (1961).

${ }^{162}$ In re "Agent Orange" Prod. Liab. Litig., 821 F.2d 139, 145 (2d Cir. 1987); Poliquin v. Garden Way, Inc. 989 F.2d 527, 535 (1st Cir. 1993) ("[A] protective order, like any ongoing injunction, is always subject to the inherent power of the district court to relax or terminate the order, even after judgment."); Gambale, 377 F.3d 133, 141 (2d Cir. 2004) (citing Agent Orange, 821 F.2d at 143-45).

${ }^{163}$ United Nuclear Corp. v. Cranford Ins. Co., 905 F.2d 1424, 1427 (10th Cir. 1990) ("As long as a protective order remains in effect, the court that entered the order retains the power to modify it, even if the underlying suit has been dismissed.")

${ }^{164}$ Seugasala, 670 F. App'x at 641.

${ }^{165}$ Landis v. N. Am. Co., 299 U.S. 248, 254 (1936).

166 Goodyear Tire \& Rubber Co. v. Haegar, 137 S. Ct. 1178, 1186 (2017) (quoting Link v. Wabash R.R., 370 U.S. 626, 630-31 (1962)); see also In re Atl. Pipe Corp., 304 F.3d 135, 143 (1st Cir. 2002); Arthur Pierson \& Co., v. Provimi Veal Corp., 887 F.2d 837, 839 (7th Cir. 1989).

${ }^{167}$ Daniel J. Meador, Inherent Judicial Authority in the Conduct of Civil Litigation, 73 Tex. L. REV. $1805,1805(1995))$.
} 
Article III(1) courts can, for instance, demand that defense counsel commit to a date for trial. ${ }^{168}$ They determine the order in which issues will be considered. ${ }^{169}$ They can initiate proceedings by declaring parties ready for trial. ${ }^{170}$ They can consolidate questions involving common law and fact ${ }^{171}$ as well as entire cases. ${ }^{172}$ Relatedly, they can stay an action pending the completion of a related action in another court. ${ }^{173}$ Courts can restrict pretrial hearing length. ${ }^{174}$ And they can implement a range of restrictions in the conduct of trial, such as limits on the number of expert witnesses. ${ }^{175}$ They can require parties to have representatives with settlement authority. ${ }^{176}$ They can limit the amount of time counsel can speak. ${ }^{177}$ On similar grounds (and subject to appellate review), courts on their own authority can dismiss an action on grounds of forum non conveniens - despite the fact that a parallel authority has been established statutorily.

\section{Protect the Integrity, Independence, and Reputation of the Judiciary}

As their own branch of government Article III(I) courts also have the inherent power to protect the integrity, independence, and reputation of the judiciary. Like matters that go to the heart of adjudication, these authorities are protected, under separation of powers doctrine, from interference by the other branches. The judiciary, for instance, has the inherent authority to prevent fraud on the court. They can launch their own, independent investigation. ${ }^{178}$ And they can set aside decisions if they are later found to be rooted in fraudulent representation. ${ }^{179}$ This power is rooted in the extension of Supreme Court jurisdiction to cases in equity under Article III(2). Along similar lines, Article III(1) courts have the inherent authority to sanction contumacious behavior, such as failure to

\footnotetext{
${ }^{168}$ United States v. Hughey, 147 F.3d 423, 430-31 (5th Cir. 1998).

${ }^{169}$ Marinechance Shipping, Ltd. v. Sebastian, 143 F.3d 216, 218 (5th Cir. 1998).

${ }^{170}$ See Williams v. New Orleans Pub. Serv., Inc., 728 F.2d 730, 732 n.4 (5th Cir. 1984).

${ }^{171}$ Bowen v. Chase, 94 U.S. 812, 824 (1876). This power was later acknowledged by statute. FED. R. CIV. P. 42(a).

172 MacAlister v. Guterma, 263 F.2d 65, 68 (2d Cir. 1958).

${ }^{173}$ Landis v. N. Am. Co., 299 U.S. 248, 254 (1936); see also Colo. River Water Conservation Dist. v. United States, 424 U.S. 800, 817 (1976); Younger v. Harris, 401 U.S. 37, $43-44$ (1971); La. Power \& Light Co. v. City of Thibodaux, 360 U.S. 25, $27-29$ (1959); Burford v. Sun Oil Co., 319 U.S. 315, 332-33 (1943); R.R. Comm'n of Tex. v. Pullman Co., 312 U.S. 496, 500-01 (1941).

${ }^{174}$ See J.S. Pharm. Distribs., Inc. v. Save-On Drugs \& Cosmetics Corp., 893 F.2d 1201, 1209 (11th Cir. 1990).

175 See Aetna Cas. \& Sur. Co. v. Guynes, 713 F.2d 1187, 1193 (5th Cir. 1983). But see United States v. Colomb, 419 F.3d 292, 301-02 (5th Cir. 2005).

${ }^{176}$ In re Stone, 986 F.2d 898, 903 (5th Cir. 1993) (per curiam); see also In re Novak, 932 F.2d 1397, 1407 (11th Cir. 1991); Luis C. Forteza e Hijos, Inc. v. Mills, 534 F.2d 415, 418-19 (1st Cir. 1976).

177 See United States v. Maloof, 205 F.3d 819, 828 (5th Cir. 2000); United States v. Gray, 105 F.3d 956, 964-65 (5th Cir. 1997); Sims v. ANR Freight Sys., Inc., 77 F.3d 846, 849 (5th Cir. 1996).

178 Universal Oil Prod. Co. v. Root Refin. Co., 328 U.S. 575, 580 (1946).

${ }^{179}$ As the Supreme court explained, the "historic power of equity to set aside fraudulently begotten judgments" is central to judicial integrity because "tampering with the administration of justice in [this] manner . . involves far more than an injury to a single litigant. It is a wrong against the institutions set up to protect and safe-guard the public.” Hazel-Atlas Glass Co. v. Harford-Empire Co., 322 U.S. 238, 245, 246 (1946)); see also Universal Oil Prods. Co, 328 U.S. at 580 (citing Hazel-Atlas, 322 U.S. 238; Chambers v. NASCO, Inc., 501 U.S. 32, 44 (1991) (quoting Hazel-Atlas, 322 U.S. at 245, 246).
} 
prosecute. ${ }^{180}$ The judiciary can penalize parties for litigating in bad faith. ${ }^{181}$ The court can fine an attorney when a party has "acted in bad faith, vexatiously, wantonly, or for oppressive reasons." 182 It goes to the court's ability to ensure that its own operations are regarded as just. It thus "transcends a court's equitable power concerning relations between the parties and reaches a court's inherent power to police itself." ${ }^{183}$ Even where there are procedural rules in place, courts can impose sanctions under their inherent powers. ${ }^{184}$ This includes sanctioning a party for "delaying or disrupting the litigation, or by hampering enforcement of a court order." 185 And courts can go further: in some circumstances, they can dismiss an appeal or complaint entirely. ${ }^{186}$

Contempt, too, falls within this category. Traditionally, it has been understood to mean misconduct in the presence of the court, disobeying court orders, or misbehavior by judicial officers. Despite considerable legislation governing this area, there are numerous cases in which the Court has underscored its own, inherent authority, distinct from the statutory basis. ${ }^{187}$ In 1821, the Court explained that Article III entities are "universally acknowledged to be vested, by their very creation, with power to impose silence, respect and decorum in their presence, and submission to their lawful mandates, and as a corollary to this proposition, to preserve themselves and their officers from the approach and insults of pollution." 188 Certain "auxiliary and subordinate" powers can be exercised by the courts where they are "indispensable to the attainment of the ends" specified. ${ }^{189}$ In 1874 , it wrote:

The power to punish for contempts is inherent in all courts; its existence is essential to the preservation of order in judicial proceedings, and to the enforcement of the judgments, orders, and writs of the courts, and consequently to the due administration of justice. The moment the courts of the United States

\footnotetext{
${ }^{180}$ For example, in 1962, following repeated prosecutorial delays, the Court explained that its authority “to dismiss sua sponte for lack of prosecution [is] an 'inherent power,' governed not by rule or statute but by the control necessarily vested in courts to manage their own affairs so as to achieve the orderly and expeditious disposition of cases.” Link v. Wabash R.R., 370 U.S. 626, 630-31 (1962); see also Chambers, 501 U.S. at 44 (citing Link, 370 U.S. at 630-31).

${ }^{181}$ This is one of the ancient powers of the courts, which dates back (at least) to the early 17th century. See An Acte to Reforme the Multitudes and Misdemeanors of Attorneyes and Sollicitors at Lawe, 3 Jac. c. 7 (1605) (Eng.); 1 William Tidd, The Practice of The Courts of King's Bench, and Common Pleas, in Personal Actions, And Ejectment 60-61 (Philadelphia, Robert H. Small 4th Am. ed. 1856). The Supreme Court first recognized this power in 1824 and has frequently reaffirmed it. See Ex parte Burr, 22 U.S. (9 Wheat.) 529, 531 (1824); Chambers, 501 U.S. at 44-45; Roadway Express, Inc. v. Piper, 447 U.S. 752, 765-66 (1980); Goodyear Tire \& Rubber Co. v. Haegar, 137 S. Ct. 1178, 1183-84 (2017) (holding that federal courts have inherent authority to sanction bad-faith conduct).

${ }^{182}$ Alyeska Pipeline Serv. Co. v. Wilderness Soc'y, 421 U.S. 240, 258-59 (1975) (quoting F.D. Rich Co. v. United States ex rel. Indus. Lumber Co., 417 U.S. 116, 129 (1974)). See also Pushaw, Jr., supra note 9, at 765 (referring to sanctioning for contumacious behavior as a "comprehensive legislative sanctioning scheme").

183 Chambers, 501 U.S. at 46.

${ }^{184} \mathrm{Id}$. at $49-50$

${ }^{185}$ Hutto v. Finney, 437 U.S. 678, 689 n.14 (1978).

${ }^{186}$ See Nat'l Hockey League v. Metro. Hockey Club, 427 U.S. 639 (1976); In re Prevot, 59 F.3d 556, 565-66 (6th Cir. 1995); D.P. Apparel Corp. v. Roadway Express, Inc., 736 F.2d 1, 3-4 (1st Cir. 1984). ${ }^{187}$ See Judiciary Act of 1789, ch. 20, § 17, 1 Stat. 73, 83 (giving federal judges "discretion" to punish "by fine or imprisonment ... all contempts of authority in any cause or hearing before the court."); United States v. Hudson, 11 U.S. (7 Cranch) 32, 34 (1812); United States v. Duane, 25 F. Cas. 920, 922 (C.C.D. Pa. 1801) (No. 14,997) (citing common law roots of judicial authority). 188 Anderson v. Dunn, 19 U.S. (6 Wheat.) 204, 227 (1821).

${ }^{189}$ Id. at 225-26.
} 
were called into existence and invested with jurisdiction over any subject, they became possessed of this power. ${ }^{190}$

Fifty years later, the Court reiterated its position, recognizing that it had a duty to punish for contempt. ${ }^{191}$ Without the ability to enforce its orders, the Court could not function. As it later explained, "The underlying concern that gave rise to the contempt power was not ... merely the disruption of court proceedings. Rather, it was disobedience to the orders of the Judiciary, regardless of whether such disobedience interfered with the conduct of trial." "192 They similarly can sanction attorneys for "willful disobedience of a court order." 193 This authority goes to the essential power of Article III(1) entities as the judicial branch of government.

The range of options available is broad: courts can appoint an attorney to prosecute defendants for criminal contempt. They can levy the cost of litigation. ${ }^{194}$ They can bar individuals disrupting a trial from the courtroom. ${ }^{195}$ Judges can require silence, respect, and decorum in their presence. ${ }^{196}$ And they can influence bar admission and discipline. ${ }^{197}$ While such power "ought to be exercised with great caution," it is nevertheless "incidental to all Courts." 198

\section{ENUMERATED POWERS TRIBUNALS: ARTICLE I(8)}

The earliest doctrinal distinction between Article III courts and Article I courts is said to have come in 1828 with the Supreme Court's decision in American Insurance Co. $v$. Canter. ${ }^{199}$ In it, the Court had to determine the legal status of the Superior Court of Florida, a territorial court established by Congress. It concluded that the legislature could carve out a domain not subject to Article III. In his analysis, Chief Justice Marshall underscored the fact that upon appointment to the territorial court, judges did not enjoy life tenure. Instead, they held office for four years:

These Courts, then, are not constitutional Courts, in which the judicial power conferred by the Constitution on the general government, can be deposited. They are incapable of receiving it. They are legislative Courts, created in virtue

${ }^{190}$ Ex parte Robinson, 86 U.S. (19 Wall.) 505, 510 (1874).

${ }^{191}$ Cooke v. United States, 267 U.S. 517, 539 (1925) ("[A] judge must have and exercise [powers of contempt] in protecting the due and orderly administration of justice, and in maintaining the authority and dignity of the court."). See also Michaelson v. United States ex rel. Chicago, St. P. M. \& O. Ry. Co., 266 U.S. 42, 65 (1924) ("[T] he power to punish for contempts is inherent in all court, has been many times decided and may be regarded as settled law. It is essential to the administration of justice.").

192 Young v. United States ex rel. Vuitton et Fils S.A., 481 U.S. 787, 798 (1987). See also Shillitani v. United States, 384 U.S. 364, 370 (1966).

${ }^{193}$ Fleischmann Distilling Corp. v. Maier Brewing Co., 386 U.S. 714, 718 (1967). See also Chambers v. NASCO, Inc., 501 U.S. 32, 46 (1991) ("[T] he inherent power extends to a full range of litigation abuses.")

194 Toledo Scale Co. v. Computing Scale Co., 261 U.S. 399, 428 (1923).

195 See Illinois v. Allen, 397 U.S. 337, 343-44, 346-47 (1970); Chambers, 501 U.S. at 44 (citing Illinois, 397 U.S. 337).

${ }^{196}$ Anderson v. Dunn, 19 U.S. (6 Wheat.), 204, 227 (1821); Chambers, 501 U.S. at 43 (quoting Anderson v. Dunn, 19 U.S. at 227).

197 See Ex parte Burr, 22 U.S. (9 Wheat.) 529, 531 (1824); Roadway Express, Inc. v. Piper, 447 U.S. 752, $766(1980)$.

${ }^{198}$ Burr, 22 U.S. at 531; see also Chambers, 501 U.S. at 42-43 (quoting Ex parte Burr, 22 U.S. at 531); cf. Roadway Express, 447 U.S. at 764 (quoting United States v. Hudson, 11 U.S. (7 Cranch) 32, 34

(1812) (some implied powers are "necessary to the exercise of all others")).

199 Am. Ins. Co. v. 356 Bales of Cotton (Canter), 26 U.S. (1 Pet.) 511 (1828). 
of the general right of sovereignty which exists in the government, or in virtue of that clause which enables Congress to make all needful rules and regulations, respecting the territory belonging to the United States. The jurisdiction with which they are invested, is not a part of that judicial power which is defined in the $3 \mathrm{~d}$ article of the Constitution, but is conferred by Congress, in the execution of those general powers which that body possesses over the territories of the United States. $^{200}$

Although Article III reserved "all cases of admiralty and maritime jurisdiction" to courts established under its auspices, "the same limitation does not extend to the territories. In legislating for them, Congress exercises the combined powers of the general [i.e., federal], and . . . state government." 201 Legislative courts could therefore be distinguished both by the constitutional protections extended to the judges, as well as the type of power being exercised.

Marshall's endorsement of the legitimacy of the Floridian territorial court in Canter relied on the text of Article IV, as well as "the general right of sovereignty" residing in government. Reference to this case as establishing the distinction between Article III and "Article I" courts therefore can only amount to a shorthand way of saying that territorial courts are brought into being by Congress. The authority underpinning their creation derives from a different part of the Constitution. Nevertheless, Canter is frequently cited in reference to the distinction between Article III courts and what are referred to as "Article I", "legislative", or "non-constitutional" tribunals.

Certainly, there is an important distinction to be drawn: Article I tribunals cannot exercise the judicial power of the United States, even as, under separation of powers doctrine, the other branches cannot interfere in the inner workings of Article III entities. Courts thus must at times delineate which entities fall into which category. ${ }^{202}$ In the 1864 case of Gordon v. United States, the Supreme Court considered the status of the Court of Claims. ${ }^{203}$ Initially, Chief Justice Taney determined that because it was essentially a legislative body, no appeal would lie from it to the Supreme Court. ${ }^{204}$ Taney died in 1864, before his decision issued. ${ }^{205}$ In 1865, the case was reargued. While the decision was pending, Congress repealed the statutory language to which Taney had pointed to deny jurisdiction. ${ }^{206}$ The Court, accordingly, shifted its position and claimed jurisdiction over final judgments from the court. ${ }^{207}$

In the time that has elapsed since Gordon, Supreme Court authority over the rulings of legislative courts has turned on the type of proceeding and the finality of the judgment. The Court does not review administrative proceedings. But where legislative courts exercise judicial proceedings, carry a final decision, and involve the exercise of

${ }^{200} I d$. at 546.

${ }^{201} I d$.

${ }^{202}$ See, e.g., Giorgio Foods, Inc. v. United States, 515 F. Supp. 2d 1313, 1321 (Ct. Int'1 Trade 2007)

("The Customs Court was an Article I court, while this court, as a result of the Customs Act of 1980, is an Article III court, with the same power as a district court.”); Int'l Fidelity Ins. Co. v. Sweet Little Mex. Corp., 665 F.3d 671, 678 (5th Cir. 2011) (quoting the language from Giorgio).

${ }^{203}$ See Gordon v. United States, 69 U.S. (2 Wall.) 561 (1864).

${ }^{204}$ Gordon v. United States, 117 U.S. 697, 698-700, 706 (1864), appending 69 U.S. (2 Wall.) 561 (1864).

205 United States v. Jones, 119 U.S. 477, $477-78$ (1886).

206 See Act of Mar. 17, 1866, ch. 19, 14 Stat. 9.

${ }^{207}$ De Groot v. United States, 72 U.S. (5 Wall.) 419 (1867); see also Jones, 119 U.S. 477 (Supreme Court exercising jurisdiction over an appeal from a judgment of the Court of Claims). 
Article III judicial functions, federal courts may have appellate jurisdiction. ${ }^{208}$ In the 2018 case Ortiz v. United States, for example, the Court reaffirmed that the military justice system is essentially judicial in character. ${ }^{209}$ The rationale behind the Court's determination is that where Article III jurisdiction is being exercised, then Article III protections are necessary.

The constitutional nexus for courts in this category lies in Article I(8)'s explicit grant of powers to the legislature. Most prominently, Article I(8)(9) provides for Congress "to constitute tribunals inferior to the Supreme Court." Two points here deserve notice: first, as a substantive matter, the laws and types of issues to come before entities created under Article $\mathrm{I}(8)(9)$ is cabined by the powers granted to the legislature in Article I(8). These types of courts, accordingly, find root both in Article I(8)(9) and in the other enumerated powers of Article I(8).

Second, the language of Article I(8)(9) departs in significant ways from Article III(1), in which "the judicial power" may be vested "in such inferior courts as the Congress may from time to time ordain and establish." To "ordain" is to order, or to officially decree the status of something or someone. Thus, under Article III(1), it is up to Congress to determine-i.e., to ordain - which courts are inferior to the Supreme Court and thereby carry the judicial power. Congress thus creates and designates which courts constitute the third branch. In contrast, the use of the word "tribunals" in Article I(8)(9) suggests the power to constitute adjudicatory bodies that do not necessarily exercise "the judicial power," but which ultimately (because of their inferiority) fall under Supreme Court jurisdiction. ${ }^{210}$ This power, then, is the heart of Congress's authority, as cabined by the substantive, enumerated powers, to create Article I(8) courts wherein appeal is to Article III.

Consistent with this clause, Congress has acted under a number of its authorities to constitute Article I(8)(9) tribunals. Under Article I(8)(17), which establishes Congressional control over the territory in which the seat of government is located, Congress has established courts in the District of Columbia. ${ }^{211}$ Other specialized Article I(8)(9) tribunals focus on taxation, ${ }^{212}$ bankruptcy, ${ }^{213}$ post offices and roads, ${ }^{214}$ copyrights and patents, ${ }^{215}$ and the constitution and governance of the military and militia. ${ }^{216} \mathrm{An}$ associated implied power relates to Congressional authority over immigration, under which it has created immigration tribunals. ${ }^{217}$ Article $\mathrm{I}(8)(18)$ goes on to provide residual power to constitute the tribunals in a manner consistent with what is necessary

\footnotetext{
${ }^{208}$ See Ortiz v. United States, 138 S. Ct. 2165, 2172-81 (2018); Pope v. United States, 323 U.S. 1, 14 (1944); D.C. Ct. of Appeals v. Feldman, 460 U.S. 462, 482-83 (1983). Note that this is also the position that Congress appears to endorse. Cong. Rsch. SERV., Constitution of THE United States of AMERICA: ANALYSIS AND INTERPRETATION, S. Doc. No. 112-9, at 673 (Centennial ed. 2017).

${ }^{209}$ Ortiz, 138 S. Ct. at 2174.

${ }^{210}$ See also Pfander, supra note 7 (underscoring the distinction between "court" and "tribunal").

${ }^{211}$ U.S. CONST. art. I, $\S 8$, cl. 17.

${ }^{212} I d$. art. I, $\S 8$, cl. 1 .

${ }^{213} I d$. art. I, $\S 8, \mathrm{cl} .4$.

${ }^{214} I d$. art. I, $\$ 8$, cl. 7.

${ }^{215} \mathrm{Id}$. art. I, $\S 8, \mathrm{cl} .8$.

${ }^{216} I d$. art. I, § 8, cl. 11 (captures on land and water); cl. 12 (raise and support armies); cl 13 (provide and maintain a Navy), cl. 14 (make rules for the government and regulation of the land and naval forces); and, cls. 15-16 (militia).

217 The Chinese Exclusion Case (Chae Chan Ping v. United States), 130 U.S. 581, 603-4 (1889).
} 
and proper to give effect to the substantive enumerated powers, as well as to bring the tribunals themselves into operation.

A final point to make about Article I(8)(9) tribunals in contrast to other types of federal courts is the temporal priority afforded to the legislature: Congress is the first actor in bringing such tribunals into existence. In this sense, these entities differ from the Article II(2)/I(8)(3) treaty bodies, which can best be understood in terms of hybrid powers. In the latter case, the Executive acts in the first instance to reach international agreement, as a necessary but not sufficient precondition to Congress acting on its Commerce Clause authorities to bring such entities into being. See discussion, Part V, infra. They are not thus properly solely creatures of the legislative branch. A brief discussion of the enumerated courts follows.

\section{A. District of Columbia: Article I(8)(17)}

The status of the courts of the District of Columbia has alternated over time. A series of decisions in the late 19th and early 20th century underscored the position of the tribunals as legislative courts, established under Congress's plenary power to govern the District of Columbia. ${ }^{218}$ Congress could therefore assign them non-judicial functions. For instance, the Supreme Court of the District (renamed in 1936 the District Court of the United States for the District of Columbia) ${ }^{219}$ held revisory powers over patent issues, with decisions binding on the Commissioner of Patents. ${ }^{220}$ It held similar authority over public utilities commissions fixed rates, ${ }^{221}$ as the D.C. Court of Appeals had over orders of the Federal Radio Commission. ${ }^{222}$

Although the U.S. Supreme Court had previously stated in dictum that the courts of the District of Columbia were legislative (i.e., non-Article III) courts, ${ }^{223}$ in 1933 it held that they were constitutional courts, exercising the full judicial power of the United States when they adjudicated cases or controversies under Article III. ${ }^{224}$ Simultaneously, insofar as the courts carried non-judicial functions, they comported with Congress's U.S. Const. art. I, $\S 8$, cl. 17 powers. ${ }^{225}$ The Supreme Court considered Article III, $\S 1$ as limiting these authorities only in regard to tenure and compensation, but not in regard to vesting legislative and administrative powers in the courts. The Court explained, "Congress has as much power to vest courts of the District with a variety of jurisdiction and powers as a state Legislature has in conferring jurisdiction on its courts." 226

\footnotetext{
${ }^{218}$ U.S. ConST. art. I, § 8, cl. 17; Fed. Radio Comm'n v. Gen. Elec. Co., 281 U.S. 464, 468 (1930) ("[T] he courts of the District of Columbia are not created under the judiciary article of the Constitution but are legislative courts."); see also Wilber Griffith Katz, Federal Legislative Courts, 43 HARV. L. REV. 894, 899-903 (1930).

${ }^{219}$ Act of June 25, 1936, ch. 804, 49 Stat. 1921.

${ }^{220}$ Butterworth v. United States ex rel. Hoe, 112 U.S. 50, 60 (1884).

${ }^{221}$ Keller v. Potomac Elec. Power Co., 261 U.S. 428, 438-40, 442-44 (1923).

${ }^{222}$ Gen. Elec. Co., 281 U.S. at 466-68.

${ }^{223}$ Ex parte Bakelite Corp., 279 U.S. 438 (1929).

${ }^{224}$ O'Donoghue v. United States, 289 U.S. 516, 551 (1933), superseded by statute, District of Columbia Court Reform and Criminal Procedure Act of 1970, Pub. L. No. 91-358, § 111, 84 Stat. 473, 475

(codified at D.C. CodE ANN. § 11-101 (West 2019)).

${ }^{225}$ O'Donoghue, 289 U.S. at 545-46.

${ }^{226} I d$. at 545 .
} 
In 1970, Congress passed a statute that distinguished between Washington D.C.'s Article III courts (the Supreme Court, the U.S. Court of Appeals for the District of Columbia Circuit, and the U.S. District Court for the District of Columbia), and Article I courts (the District of Columbia Court of Appeals and the Superior Court of the District of Columbia). ${ }^{227}$ It assigned matters of local concern to the local court system, in which the District of Columbia Court of Appeals acted as the highest court. The U.S. Court of Appeals for the District of Columbia Circuit was given jurisdiction of appeals from judgments of the District of Columbia Court of Appeals on matters related to federal criminal law. ${ }^{228}$ Three years later, the Supreme Court upheld this distinction in Palmore v. United States. ${ }^{229}$ The defendant, who had been convicted by the Superior Court of D.C. of a felony in violation of the D.C. Code, argued that he had a Constitutional right to be tried before an Article III judge. The Court disagreed:

[T]he requirements of Art. III, which are applicable where laws of national applicability and affairs of national concern are at stake, must in proper circumstances give way to accommodate plenary grants of power to Congress to legislate with respect to specialized areas having particularized needs and warranting distinctive treatment. ${ }^{230}$

Article I(8)(17) included the authority to try local criminal cases before judges who did not have life tenure or protections against an undiminished salary. Pari passu, state courts, as well as territorial courts, could take on questions relating to federal law.

The current Superior Court of the District of Columbia is comprised of a chief judge and 61 associate judges nominated by the President after recommendation from the District of Columbia Judicial Nomination Commission. ${ }^{231}$ The commission operates by releasing a notice of any judicial vacancy and then provides three names to the President for each opening, one of which the President selects. ${ }^{232}$ That individual is then confirmed by the Senate for terms of 15 years. ${ }^{233}$ The court has jurisdiction over any civil action or other matter (at law or in equity) brought in D.C. ${ }^{234}$ It also has jurisdiction over certain criminal matters, violations of the rules and regulations of the Washington Metropolitan Area Transit Authority, certain child custody cases, the issuance of warrants for arrest, search or seizure or electronic surveillance in connection with crimes and offences committed within Washington, D.C., or for administrative inspections linked to public health, safety, and welfare. ${ }^{235}$ It has subpoena authority and contempt power. ${ }^{236}$ The court's business is governed by the Federal Rules of Civil Procedure and the Federal Rules of Criminal Procedure, as modified by the court. Any changes, however, must be approved by the District of Columbia Court of Appeals. ${ }^{237}$

\footnotetext{
${ }^{227}$ District of Columbia Court Reform and Criminal Procedure Act $\S 111,84$ Stat. at 475 (codified at D.C. Code AnN. § 11-101 (West 2019)).

${ }^{228}$ Sec. 111, 84 Stat. at 476; D.C. CodE ANN. § 11-301.

${ }^{229}$ Palmore v. United States, 411 U.S. 389, 406-07, 410 (1973).

${ }^{230} \mathrm{Id}$. at $407-408$.

${ }^{231}$ See D.C. Code ANN. $§ 11-903,1-204.33$.

232 See id. $\S 1204.34(\mathrm{~d})$.

${ }^{233}$ Id. § 1204.31(c).

${ }^{234}$ Id. § 11-921.

${ }^{235}$ Id. $\S \S 11-923,11-924,11-925,11-941$.

${ }^{236}$ Id. $\S \S 11-942,11-944$.

${ }^{237}$ Id. § 11-946.
} 
The court's decisions are reviewable by the District of Columbia Court of Appeals ${ }^{238}$ which is comprised of a chief justice and eight associate justices appointed in the same manner and for the same period as judges of the Superior Court. ${ }^{239}$ Its business is conducted according to the Federal Rules of Appellate Procedure, with whatever modifications the court makes to them. ${ }^{240}$ As the highest court for the District of Columbia, the D.C. Court of Appeals is the equivalent of a state supreme court, with its decisions reviewable by the U.S. Supreme Court on matters of federal law.

\section{B. Military}

The use of military tribunals derives from English history in which the ability of the Crown to constitute such tribunals transformed over time to a Parliamentary power. Prior to the Glorious Revolution and establishment of the English Bill of Rights, the Crown promulgated its own Articles of War, which established rules for the conduct of the military and the procedures for trying their violation. ${ }^{241}$ An exercise of royal prerogative, such rules issued at the start of hostilities and ceased operation thereafter. ${ }^{242}$ Martial law held no quarter in peacetime. ${ }^{243}$ In 1689 , however, despite the defeat of James II, a significant portion of the British army remained loyal to him. Parliament passed its first Mutiny Act, reflecting both the constitutional principle forbidding standing armies absent Parliamentary consent, and that, as a practical matter, the contemporary instability required the keeping of forces "for the Safety of the Kingdome for the Common Defence of the Protestant Religion and for the reduceing [sic] of Ireland." 244 The legislation made desertion, mutiny, and sedition a crime. ${ }^{245}$ Thereafter, in recognition of the prohibition against standing armies, Parliament annually renewed the statute. ${ }^{246}$

The Crown continued to issue Articles of War in the context of active hostilities, with the result that by the time of the American Revolution, a complex set of rules had emerged. ${ }^{247}$ Colonial legislatures followed Britain's lead by passing regulations for disciplining their militias. ${ }^{248}$ In the colony of Virginia, the House of Burgesses lifted language directly from the English statute, providing for courts-martial "to inflict

${ }^{238} I d . \S 11-721$.

${ }^{239}$ See id. $\S \S 11-702,1-204.31$ (c); For the current designation of the District of Columbia Court of Appeals, see District of Columbia Court Reform and Criminal Procedure Act of 1970, § 111, Pub. L. No. 91-358, 84 Stat. 473, 475 (codified at D.C. CoDE ANN. §§ 11-101 (West 2019)).

240 D.C. CODE ANN. § 11-743.

${ }^{241}$ Such Articles were issued, for instance, by Charles I in 1629 and 1639; Charles II in 1666 during the conflict with the Dutch; and James II in 1685 in the context of Monmouth's Rebellion. See also FRANCIS Lieber \& G. Norman Lieber, To Save the Country: A Lost Treatise on Marial LaW 110-11, 11417 (Will Smiley \& John Fabian Witt eds., 2019); WiLliam Winthrop, MiLitary LAW AND PreCEDENTS 4-8 (rev. \& enlarged 2d ed. 1920); W.S. Holdsworth, Martial Law Historically Considered, 18 L.Q. REv. $117,118-21$ (1902).

${ }^{242}$ Eugene O. Porter, The Articles of War, 8 Historian 77, 84 (1946).

${ }^{243}$ Petition of Right 1628,3 . Car. c. 1 , art. VII.

${ }^{244}$ Mutiny Act 1689, 1 W. \& M. c. 5.

${ }^{245} \mathrm{Id}$.

246 See, e.g., Mutiny Act 1764, 4 Geo. 3 c. 3; Mutiny Act 1765, 5 Geo. 3 c. 7; Mutiny Act 1766, 6 Geo. 3

c. 8 ; Mutiny Act 1767, 7 Geo. 3 c. 10 ; Mutiny Act 1768, 8 Geo. 3 c. 3 .

${ }^{247}$ See Mutiny Act 1776, 16 Geo. 3 c. 2.

${ }^{248}$ See, e.g., Mutiny Act (Pa. 1756), https://founders.archives.gov/documents/Franklin/01-06-02-0189; An Act for preventing Mutiny and Desertion (Va. 1757), 7 The Statutes at LaRge, Being A

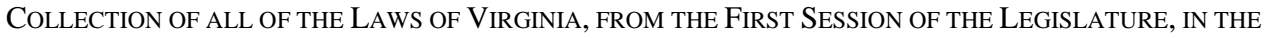
YEAR 1619, at 87 (William Waller Hening ed., Richmond 1820). 
corporal punishment, not extending to life or limb, on any soldier for immoralities, misbehaviour, or neglect of duty." ${ }^{249}$ The Massachusetts Bay code of military justice, similarly adopted by Connecticut, Rhode Island, New Hampshire, Pennsylvania, and South Carolina, reflected the British Code of $1765 .{ }^{250}$

At the drafting of the Constitution, the authority to form a military and to issue rules for its operation transferred to Congress through Articles I(8)(10), (11), (14), and (16). Nine Article I(8) courts currently in existence, ${ }^{251}$ and numerous courts over the course of U.S. history, have been introduced under these authorities. They divide into three categories, each of which has a distinct history, constitutional grounding, and appellate structure: courts-martial, military commissions, and veterans' benefits courts, each of which is discussed below. Military tribunals can be further distinguished from the other Article I(8) courts in that they depend for their execution (in part) upon the President's position of the Executive as the "Commander in Chief of the Army and Navy of the United States, and of the Militia of the several States, when called into the actual Service of the United States." 252

\section{Courts-martial: Articles I(8)(14) and (16)}

The first category of military tribunal regulates active servicemembers, ensuring good order and discipline within the military. ${ }^{253}$ This is the traditional courts-martial system, which Congress increasingly mirrors on the Article III system. It contains a three-tiered structure: courts-martial, the four courts of criminal appeals, and the U.S. Court of Appeals for the Armed Forces (the decisions of which are reviewable by the U.S. Supreme Court). ${ }^{254}$

The system itself pre-dates the Constitution: in 1775, the Second Continental Congress passed 69 Articles of War, establishing courts-martial to adjudicate their violation. $^{255}$ The rules drew extensively from the British Code of 1765 and the corresponding Massachusetts Bay requirements for its militia. ${ }^{256}$ A year later, Congress expanded the Articles. ${ }^{257}$ Further revisions occurred, the most notable of which being the shift in 1786 from requiring 13 members on general courts-martial to five, and five for special courts-martial to three. ${ }^{258}$ In 2016, the Military Justice Act expanded special

\footnotetext{
${ }^{249}$ David Glazier, Precedents Lost: The Neglected History of the Military Commission, 46 VA. J. INT'L L. 5, 17-18 (2005) (quoting from An Act for preventing Mutiny and Desertion $\S 4$, Hening, supra note 248, at 88 , and the Mutiny Act 1755, 28 Geo. 2 c. 4 (Eng.)).

${ }^{250}$ WinTHROP, supra note 241 , at $22 \&$ n. 32 .

251 These courts are the Air Force Court of Criminal Appeals, Army Court of Criminal Appeals, Coast Guard Court of Criminal Appeals, Navy-Marine Corps Court of Criminal Appeals, Court of Appeals for the Armed Forces, Court of Military Commissions Review, Court of Appeals for Veterans' Claims, and the ad hoc courts-martial and military commissions.

${ }^{252}$ See U.S. ConST. art. II, § 2, cl. 1.

${ }^{253}$ See O'Callahan v. Parker, 395 U.S. 258, 265 (1969) (“A court-martial. . remains to a significant degree a specialized part of the overall mechanism by which military discipline is preserved."), overruled on other grounds by Solorio v. United States, 483 U.S. 435, 436 (1987).

${ }^{254}$ See Weiss v. United States, 510 U.S. 163, 166-69 (1994).

255 See American Articles of War, art. XXXII, reprinted in Madsen v. Kinsella, 343 U.S. 341, 349 n. 15

(1952); WinTHROP, supra note 241, at 47-48. See also id. at 953-59.

256 WINTHROP, supra note 241 , at 22 \& n. 32.

257 Judge Advoc. GEn.'s Sch., U.S. ARMy, The BACKGRound of THE Uniform CODE OF MiLITARY

JuSTICE 2 (1959), https://www.loc.gov/rr/frd/Military_Law/pdf/background-UCMJ.pdf.

${ }^{258}$ Act of May 31, 1786, 30 Journals OF THE CONTINENTAL CONGRESS. 1774-1789, at 317-22

(Worthington Chauncey Ford ed., 1904-37). See also WINTHROP, supra note 241, at 22-23.
} 
courts-martial to four members, general courts-martial to eight, and 12 members for capital cases. ${ }^{259}$

Courts-martial were held with regularity during the Revolutionary War and early America. ${ }^{260}$ It was only natural that the Constitutional Convention went on to lodge the authority to constitute such laws and tribunals in Congress, empowering it "[t]o make Rules for the Government and Regulation of the land and naval Forces," and "[t]o provide for organizing, arming, and disciplining, the Militia, and for governing such Part of them as may be employed in the Service of the United States." ${ }^{261}$ When the U.S. Constitution came into effect, the First Congress adopted the Articles of War of 1776 to govern the Army. ${ }^{262}$ Soon thereafter, Congress passed a statute providing for governance of the Navy, which similarly provided for courts-martial. ${ }^{263}$ In recognition of the shift from the Articles of Confederation, in 1806 Congress formally enacted 101 Articles of War, which remained in force for the next seven decades. ${ }^{264}$

In 1857, the Supreme Court ruled that such tribunals are not subject to Article III requirements. ${ }^{265}$ To the contrary, the relevant provisions

show that Congress has the power to provide for the trial and punishment of military and naval offenses in the manner then and now practiced by civilized nations; and that the power to do so is given without any connection between it and the $3 \mathrm{~d}$ article of the Constitution defining the judicial power of the United States; indeed, that the two powers are entirely independent of each other. ${ }^{266}$

The Civil War prompted numerous changes to the code. ${ }^{267}$ In 1874 , Congress codified the Articles of War. ${ }^{268}$

In 1916, Congress re-enacted the Articles of War, vesting the military tribunals with the jurisdiction to try and to punish servicemembers for violations of both state and federal law. ${ }^{269}$ They subsequently underwent numerous revisions. The 1920 Articles of War, for instance, required the convening authority to appoint a defense counsel for both special and general courts (although it did not need to be an attorney). ${ }^{270}$ Starting in 1921, they were accompanied by a Manual for Courts-Martial, which detailed the

\footnotetext{
${ }^{259}$ Military Justice Act of 2016, Pub. L. No. 114-328, sec. 5187, § 829, 130 Stat. 2894, 2903 (codified at 10 U.S.C.A. $\$ 829$ (West)).

${ }^{260}$ See Ex parte Quirin, 317 U.S. 1, 42 n.14 (1942) (listing nearly 20 instances of military tribunals being used, of which only the first two were not courts-martial).

${ }^{261}$ U.S. Const. art. I, § 8, cls. 14, 16; Ortiz v. United States, 138 S. Ct. 2165, 2175 (2018).

${ }^{262}$ Act of Sept. 29, 1789, ch. 25, § 4, 1 Stat. 95, 96.

${ }^{263}$ See Act of Apr. 23, 1800, ch. 33, art. 17, 2 Stat. 45, 47; id. art. 35, 2 Stat. at 50.

${ }^{264}$ Act of Apr. 10, 1806, ch. 20, 2 Stat. 359; JudGe AdVOC. GEN.'s SCH., supra note 257, at 2-3.

${ }^{265}$ Dynes v. Hoover, 61 U.S. (20 How.) 65, 79 (1857).

${ }^{266} I d$.

${ }^{267}$ See, e.g., Act of Mar. 3, 1863, ch. 75, § 30, 12 Stat. 731, 736 (giving courts martial during times of "war, insurrection, or rebellion" the authority to punish capital offences committed by members of the armed services).

26814 Rev. Stat. § 1342 (1875).

${ }^{269}$ Act of Aug. 29, 1916, ch. 418, § 3, 39 Stat. 619, 650.

${ }^{270}$ See Act of June 4, 1920, ch. 227, ch. II, 41 Stat. 759, 787. See also Act of July 9, 1918, ch. 143, ch. X, 40 Stat. 845, 882 (amending arts. 52, 53, 57, 112); Act of Feb. 28, 1919, ch. 81, 40 Stat. 1211 (amending art. 50); Act of Nov. 19, 1919, ch. 112, 41 Stat. 356 (amending art. 112).
} 
procedural rules. Further amendments were made in 1937 and 1942, and in 1947 they were made applicable to the Air Force. ${ }^{271}$

With a significant number of civilians having been drafted into the military, calls for further changes resulted the following year in passage of the Elston Act, which, for the first time, authorized warrant officers and enlisted men to serve as members of both general and special courts-martial when the accused was enlisted. ${ }^{272}$ It strengthened the prohibitions on compulsory self-incrimination. ${ }^{273}$ In addition, it expanded the authority of the law member. ${ }^{274}$ The appellate bodies, in turn, were provided with broader authority to examine evidence, witnesses, and questions of fact.

In 1950, largely in response to complaints from World War II servicemembers who went on to serve in public office, Congress passed the Uniform Code of Military Justice (UCMJ), ${ }^{275}$ a comprehensive list of criminal offenses under military law and the operational rules that govern courts-martial. The purpose behind its adoption was to ensure a universal system for the armed forces, applicable during peacetime and war. Over the ensuing years, Congress made various amendments to the UCMJ, with the most sweeping changes following comprehensive examination of the UCMJ by the Military Justice Review Group 2014-2015. In 2016, Congress modernized the definitions for offenses, altered maximum penalties, created new offenses regarding computers and new technologies, standardized courts-martial, streamlined the post-trial process, and instituted other changes. ${ }^{276}$

Courts-martial are not standing courts. Convening authorities constitute each one on an individual basis to address specific allegations against particular individuals. The system has evolved to be a bottoms-up process, with the express intent of freeing it from unlawful influence from above. Thus, while courts-martial technically may be convened by the President, the Secretary of Defense, or the commander of a combatant command, in practice, they are convened by the senior commander of an installationtypically a general or flag officer. ${ }^{277}$ The members of courts-martial panels normally are of the same rank or outrank the accused and are not "peers" in the sense of how that term applies to civilian juries. ${ }^{278}$ Military judges are subject to the military chain of command and do not have the protections of good behavior or compensation provided

${ }^{271}$ See Act of Aug. 20, 1937, ch. 716, 50 Stat. 724 (amending arts. 501/2, 70); Act of Aug. 1, 1942, ch. 542, 56 Stat. 732 (amending art. 501/2); National Security Act of 1947, ch. 343, §§ 207-208, 61 Stat. 495, 502-04 (establishing the Air Force).

${ }^{272}$ Selective Service Act of 1948, ch. 625, § 203, art. 4, 62 Stat. 604, 628.

${ }^{273}$ Sec. 214 , art. 24, 62 Stat. at 631.

${ }^{274}$ Sec. 206, art. 8, 62 Stat. at 629. Following World War I, the role of the law member had altered to ensure that the individual did not serve as both the prosecutor and advisor to the court.

${ }^{275}$ See Uniform Code of Military Justice, ch. 169, 64 Stat. 107 (1950) (codified as amended at 10 U.S.C.A. $\S \S 801-946 a$ (West)). One of the most significant changes was the shift in the role of the law member from a voting member of the panel to that of a law officer, in which capacity the individual served in a more judicial capacity. See JUdGE Advoc. GEN.'s Sch., supra note 257, at 6.

${ }^{276}$ See Military Justice Act of 2016, Pub. L. No. 114-328, 130 Stat. 2000, 2894; See also 2018 Amendments to the Manual for Courts-Martial, United States, Exec. Order No. 13,825, 3 C.F.R. 325 (2019), reprinted in 3 U.S.C. $\S 801$ (2018); Implementation of the Military Justice Act of 2016, Army Directive 2018-28 (Dec. 20, 2018), https://armypubs.army.mil/epubs/DR_pubs/DR_a/pdf/web/ARN18514_AD2018_28_w_Interim_r27_10_ FINAL.pdf.

27710 U.S.C.A. $\$ \S 822-824$.

${ }^{278}$ See id. § 825(e)(1). 
to Article III courts. ${ }^{279}$ The military judge who presides over a general or special courtmartial is a commissioned officer as well as a member of the bar of the highest court of a State, and whom the Judge Advocate General certifies to qualify for duty. ${ }^{280}$

In 1969, the Supreme Court ruled that alleged offences had to be connected to the defendant's military service to be considered within military jurisdiction; however, in 1989 the Court reversed its earlier decision, making the UCMJ broadly applicable. ${ }^{281}$ To prosecute alleged violations, there are three types of courts-martial in each of the armed forces: general, special, and summary. ${ }^{282}$ The Manual for Courts-Martial establishes uniform rules of procedure that are similar to the Federal Rules of Criminal Procedure. ${ }^{283}$ Decisions are reviewable by the relevant Court of Criminal Appeals, constituted by not less than three appellate military judges ${ }^{284}$ The Court has jurisdiction over cases carrying the death penalty, dismissal of a commissioned officer, cadet, or midshipmen, dishonorable or bad-conduct discharge, or confinement for 2 or more years; confinement 6 months to 2 years directly appealed by the defendant; and any case referred to the Court by the Judge Advocate General. ${ }^{285}$ There are currently four such courts in operation: the Coast Guard, Air Force, Navy-Marine Corps, and Army Courts of Criminal Appeals, each of which operates under its own procedures. ${ }^{286}$

The final and highest court within the courts-martial structure is the United States Court of Appeals for the Armed Forces (USCAAF). ${ }^{287}$ A court of record, it has five civilian judges appointed by the President with the advice and consent of the Senate, each serving 15-year terms. ${ }^{288}$ Judges are removable for neglect of duty, misconduct, or physical or mental disability. ${ }^{289}$ The Court has jurisdiction over cases in which the sentence as affirmed by any military Court of Criminal Appeals extends to death, any cases reviewed by the Court of Criminal Appeals which the Judge Advocate General orders sent to the Court, and by granting of petitions after review by the Court of

\footnotetext{
${ }^{279}$ See id. § 826; Weiss v. United States, 510 U.S. 163, 168-69 (1994). Although the U.S. Courts-Martial, like the Military Courts of Appeals, are neither courts of record nor explicitly established under Article I, the Supreme Court has stated that they are Article I courts. See Weiss, 510 U.S. at 166-67, 168 (stating that the Military Courts of Criminal Appeals are Article I courts); id. at 166-67 (stating that the U.S. Courts-Martial are Article I courts).

28010 U.S.C.A. $\$ 826($ b).

${ }^{281}$ See O’Callahan v. Parker, 395 U.S. 258, 272 (1969); Solorio v. United States, 483 U.S. 435, 436 (1987).

${ }^{282}$ See 10 U.S.C.A. $\S 817$ (jurisdiction in general); id. $§ 818$ (general courts-martial); id. $§ 819$ (special courts-martial); $i d$. $\S 820$ (summary courts-martial).

${ }^{283}$ Rules for Courts-Martial, in MANuAl for Courts-Martial, United States II-1 to II-206 (2019 ed.). The MCM is reviewed annually. 32 C.F.R. $\S 152.1$ (2019).

${ }^{284} 10$ U.S.C.A. $\$ \S 866,862,869,864 ; 32$ C.F.R. $\$ 150.1$ (2019). See United States v. Denedo, 556 U.S. 904, 912 (2009) (stating that Navy-Marine Corps Court of Criminal Appeals (NMCCA) and Court of Appeals for the Armed Forces (CAAF) are Article I tribunals). Previously called the Military Courts of Review, in 1994 they were renamed to more clearly reflect the appellate judicial role of the tribunals. S. REP. No. 103-282, at 230 (1994); see H.R. REP. No. 103-701, at 737-38 (1994) (Conf. Rep.). 285 See 32 C.F.R. $\S 150.2$; 10 U.S.C.A. $\S 866($ b), 869(d).

${ }^{286} 32$ C.F.R. $\S 150.1$. See Courts of Criminal Appeals Rules of Practice and Procedure, 32 C.F.R. pt. 150; Joint Rules of Appellate Procedures for Courts of Criminal Appeals; United States Army Court of Criminal Appeals Rules of Appellate Procedure; United States Navy-Marine Corps Court of Criminal Appeals Rules of Appellate Procedure; United States Air Force Court of Criminal Appeals Rules of Practice and Procedure; and, United States Coast Guard Court of Criminal Appeals Rules of Practice and Procedure.

${ }^{287} 10$ U.S.C.A. $\$ 941$.

${ }^{288} I d . \S \S 941,942(\mathrm{a})-(\mathrm{b})$

${ }^{289} I d . \S 942(\mathrm{c})$.
} 
Criminal Appeals. ${ }^{290}$ It maintains its own procedures, ${ }^{291}$ with its decisions reviewable by the Supreme Court. ${ }^{292}$

\section{Military Commissions: Articles I(8)(10) and (11)}

Unlike courts-martial, which are directed at ensuring discipline within the military, military commissions apply to non-soldiers: i.e., enemy combatants and civilians in times of war. ${ }^{293}$ Their purpose is to root out enemy spies, saboteurs, and provacateurs. As a constitutional matter, commissions derive from Congress's authority "To declare War, grant Letters of Marque and Reprisal, and make Rules concerning Captures on Land and Water"; and its power "To define and punish Piracies and Felonies committed on the high Seas, and Offences against the Law of Nations." ${ }^{294}$ They thus carry with them an imprimateur of international law-particularly, provisions related to the laws of war.

According to the Supreme Court in Ex parte Quirin, the history of military commissions dates back to the Revolutionary War, when General George Washington constituted a military tribunal to try a British officer, Major John André, for espionage. ${ }^{295}$ The head of Britain's Secret Service in America, André was caught while out of uniform, conspiring with Benedict Arnold. ${ }^{296}$ Military commissions were regularly convened during the Mexican-American War and Civil War. ${ }^{297}$ Similarly, military commissions were established during the Indian Wars, Philippine Insurrection, World War II, and post-9/11 military actions premised on the 2001 Authorization for the Use of Military Force. ${ }^{298}$

In 1866, the Supreme Court determined that the use of military tribunals for civilians, even during wartime, was unconstitutional as long as the civilian courts were

\footnotetext{
${ }^{290}$ Id. $\$ 867$ (a).

${ }^{291}$ United States Court of Appeals for the Armed Forces Rules of Practice and Procedure.

29210 U.S.C. $\$ 867 \mathrm{a}$.

${ }^{293}$ See, e.g., Boumediene v. Bush, 553 U.S. 723 (2008); Hamdan v. Rumsfeld, 548 U.S. 557 (2006);

Hamdi v. Rumsfeld, 542 U.S. 507 (2004); Rasul v. Bush, 542 U.S. 466 (2004); Madsen v. Kinsella, 343

U.S. 341 (1952); Ex parte Quirin, 317 U.S. 1 (1942).

${ }^{294}$ U.S. CONST. art. I, 8, cls. 11, 10.

295 See Quirin, 317 U.S. at 31 \& n.9 (citing Proceedings of a Board of General Officers Respecting Major John André, Sept. 29, 1780 (Francis Bailey ed., Philadelphia 1780),

https://quod.lib.umich.edu/e/evans/N13491.0001.001?rgn=main;view=fulltext. But see

Glazier, supra note 249, at 18-23 (arguing that the trial was an advisory opinion). Aside from André, Washington also brought Thomas Shanks before a Board of General Officers to avoid a formal trial. See id. at 22.

296 Glazier, supra note 249, at 18.

297 See, e.g., Quirin, 317 U.S. at 31 n.10 (citing WinTHROP, supra note 241, at 832 n.66 (detailing numerous military commissions established in the course of the Mexican War); Dep't of the Pac., Gen. Ord. No. 52 (June 27, 1865) (detailing the trial of T.E. Hogg and others during the Civil War by military commission for "violations of the laws and usages of civilized war"); Dep't of the E., Gen. Ord. No. 14 (Feb. 14, 1865) (trying John Y. Beall for "violation of the laws of war"); James Hamilton, Dep't of the Ohio, Gen. Ord. No. 153 (Sept. 18, 1863) (trying soldiers and officers from the Confederate Army for "being secretly within the lines of the United States forces")). See also Ex parte Vallandigham, 68 U.S. (1 Wall.) 243 (1863).

298 See, e.g., Glazier, supra note 249249; Detlev F. Vagts, Military Commissions: A Concise History, 101 AM. J. InT'L L. 35 (2007); Peter R. Mansoor, Guantanamo and the History of Military Commissions, HoOvER INST. (Feb. 23, 2016), https://www.hoover.org/research/guantanamo-and-history-militarycommissions.
} 
still in business. ${ }^{299}$ But where, as in Ex parte Quirin, Congress explicitly sanctions the use of military commissions for offenses against the law of war, they operate. ${ }^{300} \mathrm{Such}$ was the determination of the Court again in Hamdan v. Rumsfeld, when it ruled that neither the Authorization for the Use of Military Force nor the Detainee Treatment Act expanded the President's power to convene military commissions. ${ }^{301}$ The Court's approach underscores that the authority to establish such courts relies not, narrowly, on Article II, but on Congress's Article I powers - demanding a statutory framing to meet Constitutional requirements. In acting upon such authorization, the President further relies on Article II commander-in-chief authorities. ${ }^{302}$

Military commissions are constituted by military officers and follow a different appellate structure than courts-martial. The currently-operable U.S. Court of Military Commission Review is a court of record consisting of one of more panels, each of which is composed of appellate military judges assigned by the Secretary of Defense or appointed by the President, by and with the consent of the Senate. ${ }^{303}$ The Court has jurisdiction to hear appeals from any military commission. ${ }^{304}$ It operates according to its own rules of procedure. ${ }^{305}$ Its decisions are reviewable by the U.S. Court of Appeals for the District of Columbia and, thence, to the Supreme Court. ${ }^{306}$

\section{Veterans Affairs: Article I(8)(14) and (16)}

The final military court in existence is the U.S. Court of Appeals for Veterans Claims, which, like courts-martial, is a federal court of record established pursuant to Congress's authority to make rules for the military. The court has exclusive jurisdiction to review decisions of the Board of Veterans' Appeals relating to veterans' claims regarding benefits for service-related disabilities, survivor benefits, and other benefits owed to servicemembers (e.g., funding for higher education, or waivers of debt) ${ }^{307}$ Its decisions, in turn, are reviewable by the U.S. Court of Appeals for the Federal Circuit. ${ }^{308}$ The court is composed of at least three and not more than seven judges, appointed by and with the advice and consent of the Senate, for terms of 15 years. ${ }^{309}$

\section{Federal Claims: Article I(8)(1)}

From the Founding of the United States until just before the Civil War, Congress received and decided private claims against the United States through its committee

\footnotetext{
${ }^{299}$ See Ex parte Milligan, 71 U.S. (4 Wall.) 2 (1866).

${ }^{300}$ Quirin, 317 U.S. at 28.

${ }^{301}$ Hamdan v. Rumsfeld, 548 U.S. 557, 593-94 (2006).

302 See, e.g., Proclamation No. 2561, PUB. PAPERS 296 (July 7, 1942) (citing both statutory law and the commander-in-chief provisions).

30310 U.S.C.A. \$ 950f (West); see also In re Khadr, 823 F.3d 92, 96 (D.C. Cir. 2016) (stating that the Military Commissions Act of 2009 established an Article I court of record). Note, however, that the Court in Hamdan, discussing the interplay of Article I(8)(10), (11), (12), (14), and Article II did not definitively rule on whether the President could constitutionally convene a military commission without sanction by Congress under the Commander-in-Chief authority, augmented by the Law of War. See Hamdan, 548 U.S. at 591.

${ }^{304} 10$ U.S.C.A. \$ 950c.

${ }^{305}$ United States Court of Military Commission Review Rules of Practice.

30610 U.S.C.A. $\$ 950 \mathrm{~g}(\mathrm{a})$, (e).

30738 U.S.C.A. $\$ 7252$.

${ }^{308}$ Id. $\$ 7292$.

30938 U.S.C.A. § 7253; see also id. §7251.
} 
system and congressional entities, followed by private appropriations bills subject to bicameralism and presentment. Addressing such concerns was part and parcel of the political process. But the number of petitions rapidly grew: by 1838, the volume had increased sixfold over those presented to the First Congress, making it impossible to consider, much less dispose of, most grievances. ${ }^{310}$ As one scholar opined, "[b]y 1848, the dissatisfaction had turned to crisis. For the first time, the legitimacy of the 'legislative model' [of redressing grievances] came under widespread political attack." 311 With only one out of every 18 claimants petitions successfully passing the House and Senate, ${ }^{312}$ the system was no longer merely expensive-it was unjust.

Accordingly, in 1855, Congress created the Court of Claims to hear certain matters, while still retaining control over both the expenditure of all public money and the authority to continue to hear individual grievances. ${ }^{313}$ Its role was to determine certain claims against the federal government as well as claims referred by Congress. ${ }^{314}$ The statute required the court to report back to Congress, which decided whether it would pay the recommended judgment out of the public funds. Congress provided for the three jurists to be appointed and to serve in office in a manner that echoed Article III: nomination by the President, confirmation by the Senate, and tenure during good behavior. ${ }^{315}$ The constitutional nexus for the creation of the tribunal was found in Congress's control over the power to pay the debts of the United States, as encapsulated in Article I(8)(1), in concert with the Necessary and Proper Clause.

The structure failed to address the underlying problem. The number of unaddressed grievances continued to increase. ${ }^{316}$ Further augmented by a flood of Civil War claims, matters came to a head. In 1863, Congress therefore gave the court the power to issue its own decisions, instead of merely reporting its determinations to the legislature. ${ }^{317}$ The statute still required the Secretary of the Treasury to review the decisions and to estimate the appropriation prior to any disbursement of funds. ${ }^{318}$

Two years later, in Gordon v. United States, the Supreme Court refused jurisdiction over appeals from the court. ${ }^{319}$ No formal opinion accompanied the denial. Upon becoming Chief Justice, though, Salmon P. Chase published one attributing it to the provision according Treasury the power of review. ${ }^{320}$ It was within Congress's power to establish an entity to examine testimony and to determine the validity of claims. The problem was trying to insert the Supreme Court into the process. The prospect of its opinions being regulated by the executive or legislative branches raised separation of powers concerns. In 1792, five of the six Supreme Court justices had rejected a similar legislative structure in Hayburn's Case-a point underscored the following year in

\footnotetext{
${ }^{310}$ See H.R. Rep. No. 25-730, at 4, 8-9 (1838).

${ }^{311}$ Floyd D. Shimomura, The History of Claims Against the United States: The Evolution from a Legislative Toward a Judicial Model of Payment, 45 LA. L. REV. 625, 649 (1985).

${ }^{312}$ See id.

${ }^{313}$ See Act of Feb. 24, 1855, ch. 122, 10 Stat. 612.

${ }^{314} I d . \S 1,10$ Stat. at 612 .

${ }^{315} \mathrm{Id}$.

316 Shimomura, supra note 311 , at 653 .

317 See Act of Mar. 3, 1863, ch. 91, 12 Stat. 765.

${ }^{318} I d . \S 14,12$ Stat. 768.

${ }^{319}$ Gordon v. United States, 69 U.S. (2 Wall.) 561 (1864).

${ }^{320}$ Gordon v. United States, 7 Ct. Cl. 1 (1871). Twenty-one year's after Chief Justice Taney's death, a draft opinion by him also emerged, linking the Court's denial of jurisdiction to the requirement that the Court's ruling be final and enforceable. See Gordon v. United States, 117 U.S. 697 (1864).
} 
Chisolm v. Georgia when it determined that the Court could hear claims against states, with their decision final (thus prompting the 11th Amendment). ${ }^{321}$

Within a year of the Court's refusal of jurisdiction in Gordon v. United States, Congress struck the offending provision from the statute. ${ }^{322}$ Thereafter, the Supreme Court agreed to hear appeals from the Court of Claims. ${ }^{323}$ In 1886, the Court held that "as the law now stands, appeals do lie to this court from the judgments of the court of claims, in the exercise of its general jurisdiction." ${ }^{24}$ In 1887, Congress passed legislation expanding the Court of Federal Claims's jurisdiction to all claims except tort and restricting what could go to Congress, making the court the primary venue for monetary claims against the United States. ${ }^{325}$

Throughout this time, the court operated as an Article I(8) entity. In Williams $v$. United States, it noted that what started as an administrative or advisory body had evolved into a court exercising judicial power and capable of rendering final judgements reviewable by the Supreme Court. ${ }^{326}$ There was no constitutional tension in maintaining two parallel systems, with final appeal lodged in Article III: while Article III(2)(1) extends the judicial power to "all" cases relating to certain areas, it omitted the word in regard to controversies to which the United States shall be a party. This meant that cases could start in Article $\mathrm{I}(8)(9)$ tribunals.

As Congress became more focused on matters of national and international concern in the mid-20th century, the federal judiciary assumed the responsibility of determining virtually all claims against the United States. ${ }^{327}$ Then, in 1953, as discussed in Part II(B)(5), Congress declared the U.S. Court of Claims to be an Article III court. ${ }^{328}$ Six years later, the Supreme Court confirmed the court's status. ${ }^{329}$ In 1982, however, Congress turned the tribunal back into an Article I Court. ${ }^{330}$ Currently, it thus operates as an Article I court, subject to review in the U.S. Court of Appeals for the Federal Circuit (itself an Article III court). ${ }^{331}$

\footnotetext{
${ }^{321}$ See Hayburn's Case, 2 U.S. (2 Dall.) 409, 410 n.† (1792) (five of the six Justices declining to hear the claims and questioning the constitutionality of the Invalid Pensions Act of 1792, ch. 11, 1 Stat. 243, whereby disabled veterans could apply for pensions to the U.S. Circuit Courts, with their decisions subject to a stay by the Secretary of War pending further Congressional action); Chisolm v. Georgia, 2 U.S. (2 Dall.) 419 (1793) (holding that Art. III(2) abrogated state sovereign immunity and provided for the justiciability of suits between private citizens and states), superseded by U.S. CONST. amend. XI. While the latter case is most often understood as a matter of state versus federal power, Federalists at the time were also concerned about its implications for transferring the responsibility for the allocation of federal monies to the judiciary. See Shimomura, supra note 311, at 642-43.

${ }^{322}$ Act of Mar. 17, 1866, ch. 19, 14 Stat. 9.

${ }^{323}$ See De Groot v. United States, 72 U.S. (5 Wall.) 419 (1866); United States v. Alire, 73 U.S. (6 Wall.) 577 (1867) (mem.); United States v. O’Grady, 89 U.S. (22 Wall.) 641 (1874); Langford v. United States, 101 U.S. 341 (1879).

${ }^{324}$ United States v. Jones, 119 U.S. 477, 480 (1886).

${ }^{325}$ See Tucker Act of 1887, ch. 359, 24 Stat. 505.

${ }^{326}$ See Williams v. United States, 289 U.S. 553, 567-68, 581 (1933).

${ }^{327}$ The claims court does not have exclusive jurisdiction over claims against the United States. See 28 U.S.C.A. $\S 1346(a), 1491$ (b)(1) (West) (conferring concurrent jurisdiction on district courts and the court of claims for certain actions).

${ }^{328}$ Act of July 28, 1953, Pub. L. No. 83-158, 67 Stat. 226.

${ }^{329}$ Glidden Co. v. Zdanok, 370 U.S. 530, $569-71$ (1962) (Harlan, J., plurality opinion).

${ }^{330}$ Federal Courts Improvement Act of 1982, Pub. L. No. 97-164, sec. 105, § 171, 96 Stat. 25, 27 (codified as amended at 28 U.S.C.A. $§ 171$ ).

33128 U.S.C.A. §§ 171(a), 1295(a)(3); see also Federal Courts Administration Act of 1992, Pub. L. No. 102-572, § 902(a), 106 Stat. 4506, 4516 (assigning the name "United States Court of Federal Claims").
} 


\section{Taxes and Customs: Article I(8)(1)}

Other legislative courts stem from so-called public rights, such as those related to taxes, customs, and administration of public lands. The public rights distinction was first identified by the Supreme Court in 1855. The Court explained,

[T] here are matters, involving public rights, which may be presented in such form that the judicial power is capable of acting on them, and which are susceptible of judicial determination, but which congress may or may not bring within the cognizance of the courts of the United States, as it may deem proper. Equitable claims to land by the inhabitants of ceded territories form a striking instance of such a class of cases. ${ }^{332}$

The U.S. Tax Court has nineteen members, appointed to 15 -year terms by the President with the advice and consent of the Senate. ${ }^{333}$ The court has limited subject matter jurisdiction: it may only consider cases related to taxation. ${ }^{334}$

\section{E. Bankruptcy: Article I(8)(4)}

Although the U.S. Constitution provides Congress with the authority to establish "uniform Laws on the subject of Bankruptcies throughout the United States," ${ }^{335}$ for much of the country's history, Congress did not vest federal courts with jurisdiction over bankruptcy. Three short-lived statutes marked the 19th century. In 1800, facing an economic downturn, Congress defined what would constitute an act of bankruptcy and provided for district court judges to appoint commissioners to oversee the discharge of debts in the course of bankruptcy proceedings. ${ }^{336}$ Congress repealed the act in $1803 .{ }^{337}$ Nearly 40 years later, again facing an economic depression, Congress enacted a statute that was to last only two years, during which time district courts held jurisdiction over "all matters and proceedings in bankruptcy." 338 In 1867, Congress again waded into the water, granting district courts original jurisdiction over bankruptcy, abandoning the effort in $1878 .{ }^{339}$

It was not until 1898 that Congress was able to enact a lasting measure, at which time it established referees, to be appointed by district judges, to oversee bankruptcy cases and to exercise limited judicial responsibilities for matters referred by the district court. ${ }^{340}$ Subsequent amendments expanded the power accorded to the referees. ${ }^{341}$ As

\footnotetext{
${ }^{332}$ Murray's Lessee v. Hoboken Land \& Improvement Co., 59 U.S. (18 How.) 272, 284 (1855).

33326 U.S.C.A. $\$ 7443$.

${ }^{334}$ See id. $\S 7442$.

${ }^{335}$ U.S. CONST. art. I, § 8, cl. 4.

${ }^{336}$ See Act of Apr. 4, 1800, ch. 19, §§ 1-2, Stat. 19, 19-22.

${ }^{337}$ Act of Dec. 19, 1803, ch. 6, 2 Stat. 248; see also David A. Skeel, Jr., The Genius of the 1898

Bankruptcy Act, 15 BANKR. DEV. J. 321, 323 (1999) (positing that the enactment and repeal of the 1800 act was in part due to a power struggle between Federalists and Jeffersonian Democrats).

${ }^{338}$ Act of Aug. 19, 1841, ch. 9, § 6, 5 Stat. 440, 445 (repealed by Act of Mar. 3, 1843, ch. 82, 5 Stat.

614).

${ }^{339}$ Act of Mar. 2, 1867, ch. 176, § 1, 14 Stat. 517, 517 (repealed by Act of June 7, 1878, ch. 160, 20 Stat. 99).

${ }^{340}$ Bankruptcy Act of 1898 , ch. 541, $\S \S 33-34,38-39,30$ Stat. 544, 555, 555-56.

${ }^{341}$ See Act of June 22, 1938, ch. 575, 52 Stat. 840; Act of June 28, 1946, ch. 512, sec. 2, § 34, 60 Stat. $323,324$.
} 
the district courts became increasingly congested, as part of a broader reform effort, the Commission on Bankruptcy Laws of the United States, created by Congress, ${ }^{342}$ recommended that a separate set of subject-specific federal courts be created. ${ }^{343}$ The Bankruptcy Reform Act of 1978 gave original jurisdiction for bankruptcy to the district courts, creating a separate, adjunct court in each judicial district to exercise the jurisdiction. ${ }^{344}$ The judges were to be appointed by the president and confirmed by the Senate, with a term of office set at 14 years. ${ }^{345}$

In 1982, the Supreme Court declared the grant of bankruptcy jurisdiction to courts constituted by judges without life tenure to be unconstitutional. ${ }^{346}$ Congress responded by passing a new statute that conferred jurisdiction on the district courts and authorizing them to refer all matters within that jurisdiction to the bankruptcy judges for the district. ${ }^{347}$ The statute also changed the manner of appointment, giving the Courts of Appeals the power to appoint judges. ${ }^{348}$

Additional amendments in 1986, 2004, and 2005 further shaped the structure. ${ }^{349}$ Currently, bankruptcy courts exist as a unit of the district court in which they reside. ${ }^{350}$ Judges are appointed by the courts of appeals of the circuit in which they are located for a term of 14 years. ${ }^{351}$ Reflecting the need for a dedicated court to relieve the district courts of the burden, there are currently 316 bankruptcy judges in the United States. ${ }^{352}$ The salary is set at 92 percent of a district court judge. ${ }^{353}$ They can be removed "only for incompetence, misconduct, neglect of duty, or physical or mental disability and only by the judicial council of the circuit in which the judge's official duty station is located." 354 Each district court may provide that any or all cases under Title 11 be assigned to a bankruptcy court. ${ }^{355}$

The decisions of the U.S. Bankruptcy courts are reviewable by the U.S. district courts or, where applicable, by a Bankruptcy Appellate Panel. ${ }^{356}$ Such panels are

\footnotetext{
342 Act of July 24, 1970, Pub. L. No. 91-354, 84 Stat. 468.

${ }^{343}$ H.R. Doc. No. 93-137, pt. 1, at 6 (1973).

${ }^{344}$ See Bankruptcy Reform Act of 1978, Pub. L. No. 95-598, sec. 201, 241, §§ 151, 1471, 92 Stat. 2549, 2657, 2668.

${ }^{345}$ Sec. 201, § 153, 92 Stat. at 2657.

${ }^{346}$ See N. Pipeline Constr. Co. v. Marathon Pipe Line Co., 458 U.S. 50, 60-62, 87 (1982), superseded by statute, Bankruptcy Amendments and Federal Judgeship Act of 1984, Pub. L. No. 98-353, 98 Stat. 333.

${ }^{347}$ Bankruptcy Amendments and Federal Judgeship Act sec. 104, § 157, 98 Stat. 333, 340 (codified as amended at 28 U.S.C.A. $§ 157$ (West)).

${ }^{348}$ Sec. 104, $§ 152,98$ Stat. at 336 (codified as amended at 28 U.S.C.A. $§ 152$ ).

${ }^{349}$ See Bankruptcy Judges, United States Trustees, and Family Farmer Bankruptcy Act of 1986, Pub. L. No. 99-554, 100 Stat. 3088; Bankruptcy Reform Act of 1994, Pub. L. No. 103-304, 108 Stat. 4106;

Bankruptcy Abuse Prevention and Consumer Protection Act of 2005, Pub. L. No. 109-8, 119 Stat. 23.

35028 U.S.C.A. $\S 151$.

${ }^{351} I d . \S 152(\mathrm{a})(1)$.

${ }^{352}$ See id. § 152(a)(2).

${ }^{353} I d . \S 153$.

${ }^{354} I d . \S 152(\mathrm{e})$

${ }^{355}$ Id. $§ 157$ (a).

${ }^{356}$ Id. $\S 158$. Note that not all circuits have Bankruptcy Appellate Panels (BAPs). See Court Insider: What Is a Bankruptcy Appellate Panel, U.S. CTS., https://www.uscourts.gov/news/2012/11/26/courtinsider-what-bankruptcy-appellate-panel (Dec. 5, 2012). The rules of the First Circuit, Sixth Circuit, Eighth Circuit, Ninth Circuit, and Tenth Circuit panels differ.
} 
composed of bankruptcy judges to hear appeals. ${ }^{357}$ Their decisions are reviewable by the relevant circuit court of appeals. ${ }^{358}$

\section{F. Citizenship: Article I(8)(4)}

The Choctaw and Chikasaw Citizenship Court, created by Congress in 1902, also operated as an Article I court. ${ }^{359}$ It came out of a series of statutes passed in the late 19th century that focused on dividing and allocating land among the Cherokee, Chickasaw, Choctaw, Creek, and Seminole nations. ${ }^{360}$ An act of Congress in 1893 established a commission to negotiate the agreement. ${ }^{361}$ Named after its chair, Senator Henry Dawes of Massachusetts, the Commission to the Five Civilized Tribes (Dawes Commission) accepted or rejected applicants for membership in the tribes based on whether the tribal government had previously acknowledged their membership. ${ }^{362}$ It distinguished among applicants as citizens by blood, citizens by marriage, minor citizens by blood, new born citizens by blood, freedmen (formerly enslaved African Americans) new born freedmen, and minor freedmen. ${ }^{363}$

Those who were unsuccessful at obtaining citizenship could appeal to the U.S. Court for the Indian Territory, which in some cases granted the appeal without notice to the Choctaw and Chickasaw nations. ${ }^{364}$ The nations objected, prompting Congress in 1902 to reach an accord with them whereby it created an Article I court. ${ }^{365}$ The President appointed a chief judge and two associate judges, by and with the advice and consent of the Senate. ${ }^{366}$

The statute authorized the tribes to file a suit in this court, with ten named defendants standing as those who had been admitted without notice. ${ }^{367}$ The law granted the court appellate jurisdiction for citizenship determinations as reached by the U.S. court in the Indian territory. ${ }^{368}$ The agreement also conferred "[e]xclusive jurisdiction upon the Commission to the Five Civilized Tribes to determine, under the direction of the Secretary of the Interior, all matters relating to the allotment of land." 369 The court, by agreement, was to terminate upon a final determination of the citizenship question, but no later than the end of 1903 - a deadline that Congress subsequently extended to

\footnotetext{
35728 U.S.C.A. $§ 158($ b)(1).

${ }^{358} I d$. $§ 158(\mathrm{~d})$.

${ }^{359}$ Act of July 21, 1902, ch. 1362, § 33, 32 Stat. 641, 648.

${ }^{360}$ See, e.g., Act of Mar. 2, 1889, ch. 412, 25 Stat. 980; Act of Mar. 3, 1893, ch. 209, 27 Stat. 612; Act of June 28, 1898, ch. 517, 30 Stat. 495; Act of May 31, 1900, ch. 598, 31 Stat. 221.

${ }^{361}$ Act of Mar. 3, 1893, ch. 209, § 16, 27 Stat. at 645.

${ }^{362}$ Dawes Records: Five Civilized Tribes-Cherokee, Chickasaw, Choctaw, Creek, and Seminole Tribes in Oklahoma, NAT'L ARCHIVES, https://www.archives.gov/research/nativeamericans/dawes?_ga=2.11424372.1336762792.1603825750-746858546.1602531796 (last visited Oct. $27,2020)$

${ }^{363} \mathrm{Id}$.

${ }^{364}$ Choctaw and Chickasaw Citizenship Court, 1902-1904, FeD. Jud. CTR., https://www.fjc.gov/history/courts/choctaw-and-chickasaw-citizenship-court-1902-1904 (last visited Oct. 27, 2020). 
the end of the following year. ${ }^{370}$ The court only operated less than seven months after reaching a final determination in just one case. ${ }^{371}$

\section{TERRITORIAL COURTS: ARTICLE IV(3)}

In 1781, the Articles of Confederation gave the national government (in Congress assembled) the power to determine admission to the union. ${ }^{372}$ Three years later, the Treaty of Paris brought a formal end to the Revolutionary War, ceding not just the thirteen colonies (at that point, nascent states), but most of Britain's possessions east of the Mississippi River. The Northwest Ordinances of 1784, 1785, and 1787 reconstituted this land as Northwest Territory, provided for its governance, and outlined the process for state admission. By the time the Constitution was adopted, it was thus clear that explicit authority had to be provided to govern such territories. Accordingly, Article IV(3), gives Congress "Power to dispose of and make all needful Rules and Regulations respecting the Territory or other Property belonging to the United States." 373

As a constitutional matter, therefore, Congress possesses and exercises absolute control over U.S. territories. ${ }^{374}$ In 1828 , the question of the status of courts in the territories came before the Supreme Court. As Part III of this Article noted, in this case Marshall pinpointed the constitutional locus as Article IV, as well as the sovereign authority of the United States. ${ }^{375}$ Just over two decades later, the Court again returned to the status of the governance structure in the territories:

They are legislative governments, and their courts legislative courts, Congress, in the exercise of its powers in the organization and government of the Territories, combining the powers of both the Federal and State authorities. There is but one system of government, or of laws operating within their limits, as neither is subject to the constitutional provisions in respect to State and Federal jurisdiction. They are not organized under the Constitution, nor subject to its complex distribution of the powers of government, as the organic law; but are the creations, exclusively, of the legislative department, and subject to its supervision and control. ${ }^{376}$

While it is true that Congress brings such entities into being, they are not Article I courts in a constitutional sense. ${ }^{377}$

Failure to acknowledge this aspect of territorial government has led to much confusion, not least in determining to what extent other Constitutional provisions apply to the territories. In the Insular Tariff Cases that marked the end of the 19th and early 20th centuries, the Supreme Court wrestled with how to understand governance of noncontiguous territory. In one of the most prominent, Downes v. Bidwell, it concluded

${ }^{370}$ Choctaw and Chickasaw Citizenship Court, supra note 364.

${ }^{371} I d$.

372 See ARTICLES OF CONFEDERATION OF 1781, art. XI (requiring the admission into the Union be agreed to by nine states).

${ }^{373}$ U.S. CONST. art. IV, § 3, cl. 2.

${ }^{374}$ See Sere v. Pitot, 10 U.S. (6 Cranch) 332, 336-337 (1810).

375 See Am. Ins. Co. v. 356 Bales of Cotton (Canter), 26 U.S. (1 Pet.) 511 (1828).

${ }^{376}$ Benner v. Porter, 50 U.S. (9 How.) 235, 242.

377 When territorial courts are addressed in the scholarship, they are frequently (and erroneously)

described as Article I courts. See, e.g., REDISH, FEDERAL JURISDICTION, supra note 7. 
that a tariff imposed on goods imported from Puerto Rico did not violate Article I constitutional provisions requiring uniform duties, imposts, and excises. ${ }^{378}$ Similarly, in Dooley v. United States, the Court upheld the Foraker Act, requiring all merchandise to Puerto Rico from the United States to carry a duty - despite the constitutional provision in Article I forbidding any tax or duty on articles exported from any state. ${ }^{379}$ No clear rationale dominated the Court's determination. Gradually, through the doctrine of territorial incorporation (which stemmed from Justice Edward White's concurrence in Downes), the application of Constitutional provisions became understood in terms of whether the territories in question had become "incorporated into the union." 380

In its exercise of is power over the myriad territories acquired by the United States, Congress has created at least four dozen separate territorial judicial systems. Every single one of the attendant courts is a non-Article III (and non-Article I) entity. ${ }^{381}$ Consistent with the doctrine, we divide these tribunals into two categories: incorporated and unincorporated territorial courts.

\section{A. Incorporated}

Outside of the original 13 states, as well as Kentucky, Vermont, Texas, California, and West Virginia, every state in the continental U.S. came within an incorporated territory prior to admission. ${ }^{382}$ In total, some thirty-one territories (or parts thereof) eventually became states. In each case, Congress created superior and inferior federal courts to execute territorial judicial power and to administer the law. ${ }^{383}$ The federal legislature also determined which legal system would be administered. Where Congress could not decide (for example, whether English, Canadian, Spanish, or Mexican rules should apply), it provided territorial courts with jurisdiction over "criminal" and "civil" cases and ensured that the pre-existing law would remain in force, to the extent that it was compatible with the U.S. Constitution. ${ }^{384}$ Where Congress intended for the adoption of the English system of law, in some cases it explicitly provided for superior

\footnotetext{
378 Downes v. Bidwell, 182 U.S. 244 (1901). See also U.S. ConST. art. I, § 8, cl. 1.

${ }^{379}$ Dooley v. United States, 183 U.S. 151 (1901). See also U.S. Const. art. I, § 9, cl. 5.

${ }^{380}$ Balzac v. Puerto Rico, 258 U.S. 298, 305 (1922).

381 See, e.g., id.; Sere v. Pitot, 10 U.S. (6 Cranch) 332, 336-337 (1810); Clinton v. Englebrecht, 80 U.S. (13 Wall.) 434, 447 (1871); Hornbuckle v. Toombs, 85 U.S. (18 Wall.) 648, 656 (1873); Good v. Martin, 95 U.S. 90, 98 (1877); Reynolds v. United States, 98 U.S. 145, 154 (1878); City of Panama, 101 U.S. 453, 460 (1879); McAllister v. United Sates, 141 U.S. 174, 184 (1891); see also Romeu v. Todd, 206 U.S. 358, 368 (1907) ("The district court of the United States for Porto Rico is in no sense a constitutional court of the United States, and its authority emanates wholly from Congress under the sanction of the power possessed by that body to govern territory occupying the relation to the United States which Porto Rico does.")

${ }^{382}$ William Wirt Blume \& Elizabeth Gaspar Brown, Territorial Courts and Law: Unifying Factors in the Development of American Legal Institutions (pt. 2), 61 Mich. L. REV. 467, 467 (1963). In 1912 the last state in the continental United States was admitted to the Union. Id.

${ }^{383}$ See, e.g., Montana Organic Act of 1864 , ch. 95, § 9, 13 Stat. 85, 88. For an excellent summary of courts established in the territories prior to 1836, see William Wirt Blume \& Elizabeth Gaspar Brown, Territorial Courts and Law: Unifying Factors in the Development of American Legal Institutions (pt. 1), 61 Mich. L. REv. 39, 45-46 (1962).

${ }^{384}$ Blume \& Brown, supra note 382, at 518. See, e.g., Act of Mar. 2, 1805 ch. 23, § 1, 2 Stat. 322, 322 (giving inhabitants of the Orleans Territory "all the rights, privileges, and advantages secured by" the Northwest Ordinance of 1787); Act of June 4, 1812, ch. 95, § 14, 2 Stat. 743, 747 (guaranteeing that judicial proceedings in the Missouri Territory would be conducted "according to the common law and the laws and usages in force in the said territory").
} 
judges to be granted common law jurisdiction. ${ }^{385}$ In others, it established that inhabitants were "entitled" to judicial proceedings consistent with common law. ${ }^{386}$ At times Congress gave superior judges both chancery and common law jurisdiction. ${ }^{387}$ In one case (Alaska), Congress indicated that "The common law of England as adopted and understood in the United States" would be in force. ${ }^{388}$

Despite such direction, considerable questions remained about what, precisely, constituted common law - an issue addressed by subsequent territorial case law and statutory provisions. ${ }^{389}$ Some looked to the common law of England and statutes that supported it prior to 1607 (the rule of decision). Others considered the law as it existed in 1776; still others looked to select British statutes. ${ }^{390}$ In all cases, the laws and system of rules adopted had to be compatible with the U.S. Constitution. ${ }^{391}$ Congress also granted territorial courts jurisdiction over other matters, such as probate (wills and conveyances of land); divorce; admiralty; and bankruptcy. ${ }^{392}$ The rules of procedure varied. In 1800, for instance, the General Assembly of Northwest required judges of the General Court "to compile a system of rules for the government of the general and circuit courts." ${ }^{\prime 393}$ In other regions, the highest court in the territory established the equivalent rules. ${ }^{394}$ Although the U.S. Supreme Court determined in 1863 that a

${ }^{385}$ See, e.g., Northwest Ordinance of 1787, ch. 8, 1 Stat. 51 n.(a) (conferring common law jurisdiction on the superior judges and ensuring that inhabitants should "always be entitled to the benefits of . . judicial proceedings according to the course of the common law"); Act of Apr. 7, 1798, ch. 28, § 6, 1 Stat. 549, 550 (guaranteeing the people of Mississippi "the rights, privileges and advantages" granted by the Northwest Ordinance of 1787); Act of May 7, 1800, ch. 41, § 2, 2 Stat. 58, 59 (conferring common law jurisdiction on Indiana courts through incorporation of the Northwest Ordinance of 1787); Act of Jan. 11, 1805, ch. 5, § 2, 2 Stat. 309, 309 (conferring common law jurisdiction on the Michigan Territory through incorporation by reference of the Northwest Ordinance of 1787).

${ }^{386}$ See, e.g., Northwest Ordinance of 1787, ch. 8, 1 Stat. 51 n.(a) (conferring common law jurisdiction on the superior judges and ensuring that inhabitants should "always be entitled to the benefits of . . judicial proceedings according to the course of the common law."); Act of Apr. 20, 1836, ch. 54, § 12, 5 Stat. 10, 15 (entitling inhabitants of the Wisconsin Territory benefits granted and secured in the Northwest Ordinance of 1787); Act of Aug. 14, 1848, ch. 177, § 14, 9 Stat. 323, 329 (entitling inhabitants of the Oregon Territory to the "rights, privileges, and advantages granted and secured" by the Northwest Ordinance of 1787).

${ }^{387}$ See, e.g., Act of Sept. 9, 1850, ch. 51, § 9, 9 Stat. 453, 455 (Utah); Act of Mar. 2, 1853, ch. 90, § 9, 10 Stat. 172, 1776 (Washington); Act of May 30, 1854, ch. 59, $\S \$ 9,27,10$ Stat. 277, 280, 286 (Nebraska and Kansas); Act of Feb. 28, 1861, ch. 59, § 9, 12 Stat. 172, 174 (Colorado); Act of Mar. 2, 1861, ch. 83, $\S 9,12$ Stat. 209, 212 (Nevada); Act of Mar. 2, 1861, ch. 86, § 9, 12 Stat. 239, 242 (Dakota); Act of Mar. 3, 1863, ch. 117, § 9, 12 Stat. 808, 811 (Idaho); Act of May 26, 1864, ch. 95, § 9, 13 Stat. 85, 88 (Montana); Act of July 25, 1868, ch. 235, § 9, 15 Stat. 178, 181 (Wyoming); Act of May 2, 1890, ch. $182, \S 9,26$ Stat. 81, 85 (Oklahoma).

${ }^{388}$ Alaska Criminal Code, ch. 429, 30 Stat. 1253, 1285 (1899). See also Act of May 17, 1884, ch. 53, § 7 , 23 Stat. 24, 25 (1884) (general laws of Oregon declared to be enforce within the Alaska judicial district).

${ }^{389}$ See, e.g., Hornbuckle v. Toombs, 85 U.S. (18 Wall.) 648, 652, 656-57 (1873) (ruling on the intermingling of legal and equitable remedies under common law). For a thoughtful discussion of the integration of law into the territories, see William Wirt Blume, Legislation on the American Frontier: Adoption of Laws by Governor and Judges - Northwest Territory 1788-1798; Indiana Territory 18001804; Michigan Territory 1805-1823, 60 Mich. L. REV. 317 (1962).

${ }^{390}$ See generally Blume \& Brown, supra note 382, at 477-523; Blume, supra note 389, at 333-48.

${ }^{391}$ See, e.g., ARIZ. Rev. STAT. § 2935, at 523 (1887); Alaska Civil Code, ch. 786, tit. III, § 367, 31 Stat. 321, 494, 552 (1900); see also Blume \& Brown, supra note 382, at 510, 514 (quoting the aforementioned statutes).

392 Blume \& Brown, supra note 383 , at 59-71.

393 Blume \& Brown, supra note 382, at 475 (quoting 1 STATUTES OF OHIO AND OF THE NORTHWESTERN TERRITORY ch. 141, § 9, at 307 (Salmon P. Chase ed., Cincinnati, Corey \& Fairbank 1833)).

${ }^{394}$ See id. (referencing A Digest OF the RulEs OF THE SUPREME COURT OF THE TERRITORY OF MichigAN (Detroit, Sheldon \& Reed 1821)). 
territorial court sitting in chancery was governed by the same rules governing Article III entities, in 1874 the Court reversed course. ${ }^{395}$

With the exception of some early judges, for whom Congress guaranteed office during good behavior, territorial judges were appointed for limited terms and removable by the President at will. ${ }^{396}$ For the territorial governments constructed along the lines of the Northwest Ordinance, at least three judges appointed by the President constituted the highest court in each territory, with jurisdiction over both state-type and federaltype cases. ${ }^{397}$ After 1836, Congress largely standardized its approach. ${ }^{398}$ In cases concerning the United States (and later, cases involving certain amounts), federal law provided for appeal to Article III courts. ${ }^{399}$ The U.S. Supreme Court generally acted as the highest court of appeal. ${ }^{400}$

Once statehood was achieved, territorial courts ceased operating and were replaced by Article III entities. But as long as the territory itself was the dominant government, there was no question: the courts did not constitute the judicial branch of the federal government. ${ }^{401}$ One way, therefore, to think about territorial courts collectively is as "coextensive with and correspondent to [the jurisdiction] of the State courts"-i.e., an entirely "different jurisdiction from that exercised by the Circuit and District Courts of the United States." 402 Since 1959, there have not been any incorporated (organized) territories. $^{403}$

395 Orchard v. Hughes, 68 U.S. (1 Wall.) 73, 77 (1863), overruled by Hornbuckle v. Toombs, 85 U.S. (18 Wall.) 648, 652-53 (1873).

396 See, e.g., Act of Mar. 26, 1804, ch. 38, § 5, 2 Stat. 283, 284 (Orleans); Act of June 4, 1812, ch. 95, § 10, 2 Stat. 743, 746 (Missouri); Act of Mar. 2, 1819, ch. 49, § 7, 3 Stat. 493, 495 (Arkansaw); Act of Mar. 30, 1822, ch. 13, § 8, 3 Stat. 654, 657 (Florida); Act of June 12, 1838, ch. 96, § 9, 5 Stat. 235, 23738 (Iowa); Act of Aug. 14, 1848, ch. 177, § 9, 9 Stat. 323, 326 (Oregon ); Act of Mar. 3, 1849, ch. 121, § 9, 9 Stat. 403, 406 (Minnesota); Act of Sept. 9, 1850, ch. 49, § 10, 9 Stat. 446, 449 (New Mexico); Act of Sept. 9, 1850, ch. 51, § 9, 9 Stat. 453, 455 (Utah); Act of Mar. 2, 1853, ch. 90, § 9, 10 Stat. 172, 175 (Washington); Act of May 30, 1854, ch. 59, § 9, 10 Stat. 277, 280 (Nebraska); Act of May 30, 1854, ch. 59, § 279, 10 Stat. 277, 286 (Kansas); Act of Feb. 28, 1861, ch. 59, § 9, 12 Stat. 172, 174 (Colorado); Act of Mar. 2, 1861, ch. 83, § 9, 12 Stat. 209, 212 (Nevada); Act of Mar. 2, 1861, ch. 86, § 9, 12 Stat. 239, 241 (Dakota); Act of Feb. 24, 1863, ch. 56, § 2, 12 Stat. 664, 665 (Arizona); Act of Mar. 3, 1863, ch. 117, $\S 9,12$ Stat. 808, 811 (Idaho); Act of May 26, 1864, ch. 95, § 9, 13 Stat. 85, 88 (Montana); Act of July 25, 1868, ch. 235, § 9, 15 Stat. 178, 180-81 (Wyoming); Act of May 2, 1890, ch. 182, § 9, 26 Stat. 81, 85 (Oklahoma). See also McAllister v. United Sates, 141 U.S. 174, 185 nn.1-2 (1891) (citing to these acts); Blume \& Brown, supra note 382, at 468; Blume \& Brown, supra note 383, at 47.

${ }^{397}$ Blume \& Brown, supra note 382, at 477.

398 See Blume \& Brown, supra note 383 , at 49-51.

${ }^{399}$ Blume \& Brown, supra note 382, at 477 . There are no published reports of early territorial cases. See $i d$. at 477 n.70.

${ }^{400}$ See, e.g., Orchard, 68 U.S. 73 (on appeal from the Territorial Court of Nebraska).

401 See, e.g., City of Panama, 101 U.S. 453, 460 (1879); McAllister v. United Sates, 141 U.S. 174, 184 (1891); Clinton v. Englebrecht, 80 U.S. (13 Wall.) 434, 447 (1871) .

${ }^{402}$ Hornbuckle v. Toombs, 85 U.S. (18 Wall.) 648, 656 (1873). See also Benner v. Porter, 50 U.S. (9 How.) 235, 244 (1850).

403 There is currently one incorporated (unorganized) territory: the Palmyra Atoll, a national wildlife refuge of approximately 50 islands owned by the Nature Conservancy and administered by U.S. Fish \& Wildlife Service. One of the largest marine conservation areas globally, the archipelago features pristine coral reefs, thermal vents, and the Masked Booby. See Definitions of Insular Area Political Organizations, U.S. DEP'T OF THE INTERIOR, https://www.doi.gov/oia/islands/politicatypes (last visited Jan. 5, 2021) (listed under definitions for incorporate territory and Territory); Palmyra Atoll, U.S. FISH \& WILDLIFE SERV., https://www.fws.gov/refuge/palmyra_atoll/ (last visited Jan. 5, 2021). 


\section{B. Unincorporated}

Unincorporated territories describe regions where the U.S. Constitution has not been fully incorporated. While fundamental rights are guaranteed, other provisions are inapplicable. The Panama Canal provides a special case in that the tribunal established there grew out of a statutorily-based territorial governance structure but was eventually incorporated into the Fifth Circuit. It thus more closely resembles the current territorial courts in existence, of which there are three.

The Panama Canal Zone provided a home for one of the first unincorporated territorial courts. The 1902 Spooner Act authorized the President to purchase the rights and property of the (French) New Panama Canal Company and to secure "perpetual control of a strip of land, the territory of the Republic of Colombia, not less than six miles in width, extending from the Caribbean Sea to the Pacific Ocean" and the right to build a canal and to maintain and operate the Panama Railroad in perpetuity. ${ }^{404}$ Should Columbia not concede, the President was to negotiate the same from Costa Rica and Nicaragua. ${ }^{405}$ The statute created an Isthmian Canal Commission, with seven members appointed by the President with the advice and consent of the Senate to govern the region and oversee construction of the canal, "subject to the direction and control of the President." ${ }^{406}$ Although the Senate ratified the treaty, the Colombian congress rejected it. ${ }^{407}$

When the Republic of Panama declared its independence in 1903, the U.S. landed marines and informed Colombia that it would not allow trade to be jeopardized. ${ }^{408}$ It recognized the new government and drafted a new treaty which, in return for guaranteeing Panama's independence, conveyed a ten miles wide zone to the sovereign control of the United States. ${ }^{409}$ It further granted a monopoly in perpetuity for canals and railways across the territory. Both governments ratified the agreement. General W. Davis, the first governor, appointed a judge to exercise judicial authority. ${ }^{410}$

For its first decade or so, governance was under direct control of the President. In 1912, however, Congress assumed more direct control, establishing civil government and directing that the current laws would remain in effect only until Congress should provide otherwise. ${ }^{411}$ It recognized "[ $\left.t\right]$ he existing courts established in the Canal Zone by Executive order" and continued them in operation until the courts provided for in the statute were established. ${ }^{412}$ It also established a District Court for the Canal Zone, with decisions appealable to the Fifth Circuit. ${ }^{413}$ In 1914, by authorities vested in this Act, President Woodrow Wilson issued an Executive Order abolishing the prior structure and, consistent with legislative provisions directed at wartime, placed the canal under the control of the Secretary of War. ${ }^{414}$ Two months later, he issued a second

\footnotetext{
${ }^{404}$ Panama Canal Act of 1902, ch. 1302, §§ 1-2, 32 Stat. 481, 481.

${ }^{405} \mathrm{Id}$. $\S 4,32$ Stat. at 482.

${ }^{406} I d . \S 7,32$ Stat. at 483 .

407 ThOMAS, supra note 6 , at 315 .

${ }^{408} I d$. at $315-16$.

${ }^{409}$ Id. at 317.

${ }^{410}$ Id. at $317-18$.

${ }^{411}$ Panama Canal Act 1912, ch. 390, § 2, 37 Stat. 560, 561.

${ }^{412} I d$.

${ }^{413}$ Id. $\S 8-9,37$ Stat. at 565-66.

${ }^{414}$ Exec. Order No. 1885 (Jan. 27, 1914), https://www.presidency.ucsb.edu/documents/executive-order1885-establish-permanent-organization-for-the-operation-and-government-the.
} 
Executive Order formally establishing the U.S. District Court for the Canal Zone. ${ }^{415}$ Replacing the Supreme Court of the Canal Zone, the District Court had original and appellate jurisdiction over civil and criminal matters. In 1933, the court transferred to the U.S. Department of Justice. ${ }^{416}$ The court thereafter operated until the return of the zone to Panama in $1982 .{ }^{417}$

Cuba, Philippines, the Trust Territory of the Pacific Islands, the Marshall Islands, Micronesia, and Palau provide further examples of former U.S. territories that have since become independent. Currently, there are thirteen insular (unincorporated) areas, only five of which (Guam, the Northern Mariana Islands, the U.S. Virgin Islands, Puerto Rico, and American Samoa) are inhabited, and only three of which have territorial courts. ${ }^{418}$

Guam, one of the Mariana Islands, was ceded by Spain to the United States in 1899. ${ }^{419}$ In 1950, Congress passed a statute giving the protectorate a significant amount of local autonomy. ${ }^{420}$ The District Court of Guam has the same jurisdiction of a regular federal District Court (including, but not limited to, diversity jurisdiction), as well as that of a bankruptcy court. ${ }^{421}$ The District Court of Guam has original jurisdiction in all other causes in Guam to the extent that the legislature has not vested it in another court. ${ }^{422}$ Decisions are reviewable by the Ninth Circuit Court of Appeals. ${ }^{423}$ Judges, appointed by the President to ten year terms, are removable for cause and accorded a salary commensurate with that of a district court judge. ${ }^{424}$ The court supplements the Federal Rules of Civil Procedure with Civil Local Rules of Practice (CVLR).

The District Court for the Northern Mariana Islands is part of the same judicial circuit as Guam. ${ }^{425}$ Granted a similar scope for its jurisdiction, the court is made up of just one judge, appointed by the President for a ten-year term. ${ }^{426}$ Like the District Court of Guam, appeal is to the Ninth Circuit. ${ }^{427}$ Both the Chief Judge of the Ninth Circuit and the Chief Justice may assign additional, temporary judges to the court. ${ }^{428}$

\footnotetext{
${ }^{415}$ Exec. Order No. 1898 (Mar. 12, 1914), https://en.wikisource.org/wiki/Executive_Order_1898.

${ }^{416}$ Exec. Order No. 6166, § 6 (June 10, 1933) (transferring the U.S. Court for China, the District Court of the United States for the Panama Canal Zone, and the District Court of the Virgin Islands to the Department of Justice), https://www.archives.gov/federal-register/codification/executiveorder/06166.html.

${ }^{417}$ Panama Canal Act of 1979, Pub. L. No. 96-70, §§ 2101, 2201, 93 Stat. 452, 493.

418 See Definitions of Insular Area Political Organizations, supra note 403; The Territories: They Are Us, ST. LEGISLATURES, Jan. 2018, at 27.

419 Treaty of Paris, Spain-U.S., art. II, Dec. 10, 1898, 30 Stat. 1754, 1755. See also 48 U.S.C.A. 1421

(West) (defining the territory of Guam).

${ }^{420}$ See Organic Act of Guam, ch. 512, § 11, 64 Stat. 384, 387 (1950) (codified as amended at 48 U.S.C.A. § 1423a) (extending authority "to all subjects of legislation of local application").

42148 U.S.C.A. § 1424(b). See also 28 U.S.C.A. $\$ 1332$ (related diversity jurisdiction provisions).

42248 U.S.C.A. § 1424(c). Congress also designated a local appellate court, the Supreme Court of Guam, and trial court, the Superior Court of Guam. Id. § 1424(a)(1). The Supreme Court of Guam has the power to create divisions of the Superior Court of Guam as well as other local courts. Id.\$ 1424(a)(2)-(3).

${ }^{423} 28$ U.S.C.A. $\S \S 1291,1294(4)$. See also 48 U.S.C.A. $§ 1424-3$ (appeal from the appellate division).

42448 U.S.C.A. $\$ 1424 b(a)$.

${ }^{425}$ Id. $\S 1821(\mathrm{a})$.

${ }^{426} I d$. $\S ~ 1821(\mathrm{~b})(1)$ (appointment), 1822 (jurisdiction).

${ }^{427}$ Id. $\S \S 1801$ note (indicating that the Act of Mar. 24, 1976, Pub. L. No. 94-241, § 403(b), 90 Stat. 263, 267 provides that portions of Title 28 that apply to the District Court of Guam are applicable to the District Court for the Mariana Islands). See also id. $\S 1823$ (appeal from the appellate division). ${ }^{428}$ Id. $\S \S 1821(\mathrm{~b})(2)$.
} 
Congress similarly vested the judicial power of the Virgin Islands in a district court and such appellate and lower courts as are created by local law. ${ }^{429}$ The local legislature has the authority to grant them jurisdiction over any matters in which the federal courts lack exclusive jurisdiction. ${ }^{430}$ Congress explicitly provided the court with diversity jurisdiction as well as that of a bankruptcy court in the United States, and exclusive jurisdiction over all criminal and civil proceedings in the Virgin Islands in regard to the applicable income tax laws. ${ }^{431}$ The district court has concurrent jurisdiction with local courts over criminal offences. ${ }^{432}$ Its decisions are reviewable by the U.S. Court of Appeals for the Third Circuit. ${ }^{433}$ The President appoints two judges to the court for 10 year terms, the longer serving of whom serves as chief judge of the court. ${ }^{434}$ The salary rate is set to that of a district court judge. ${ }^{435}$ In the event that the case load becomes untenable, the chief judge of the Third Judicial Circuit may assign a circuit judge or a recalled senior judge from the islands to temporarily serve on the court. ${ }^{436}$

Although Congress previously created a territorial court for Puerto Rico, its status has now shifted to that of an Article III entity. In its initial design, the court had one judge in office for a four-year term. ${ }^{437}$ In 1915, Congress provided for appeals from the court to go to the First Circuit Court of Appeals. ${ }^{438}$ Nevertheless, as recognized by the Supreme Court shortly thereafter, the Court continued to function in its Article IV status:

created by virtue of the sovereign congressional faculty, granted under Article $4, \S 3$ [of the Constitution], of making all needful rules and regulations respecting the territory belonging to the United States. The resemblance of its jurisdiction to that of true United States courts, in offering an opportunity to nonresidents of resorting to a tribunal not subject to local influence, does not change its character as a mere territorial court. ${ }^{439}$

In 1938, Congress doubled judges' length of tenure on the court to eight years. ${ }^{440}$ In 1966, Congress re-constituted it as a full Article III entity, with now seven judges granted life tenure during good behavior. ${ }^{441}$

\footnotetext{
${ }^{429}$ Id. $\S 1611(\mathrm{a})$.

${ }^{430}$ Id. $\S 1611(\mathrm{~b})$.

${ }^{431}$ Id. $\S 1612(\mathrm{a})$.

${ }^{432}$ Id. $\S 1612(\mathrm{c})$.

43328 U.S.C.A. $\$ \S 1291,1294(3)$; see also 48 U.S.C.A. $\S 1613$ a (appeal from the appellate division).

43448 U.S.C.A. $§ 1614($ a).

${ }^{435} \mathrm{Id}$.

${ }^{436} I d$.

${ }^{437}$ Act of Apr. 12, 1900, ch. 191, § 34, 31 Stat. 77, 84.

438 Act of Jan. 28, 1915, ch. 22, § 1-2, 38 Stat. 803, 803.

${ }^{439}$ Balzac v. Porto Rico, 258 U.S. 298, 312 (1922).

440 Act of Mar. 26, 1938, ch. 51, 52 Stat. 118, 118.

${ }^{441}$ Act of Sept. 12, 1966, Pub. L. No. 89-571, 80 Stat. 764, provided judges with lifetime tenure, thus reconstituting the court as an Article III District Court. For the statutes establishing the judgeships, see $\S$ 34, 31 Stat. at 84 (creating one judgeship); Act of May 19, 1961, Pub. L. No. 87-36, § 2, 75 Stat. 80, 81 (adding one judgeship); Act of June 2, 1970, Pub. L. No. 91-272, 84 Stat. 294, 294 (adding one judgeship); Act of Oct. 20, 1978, Pub. L. No. 95-486, 92 Stat. 1629, 1629-30 (adding four judgeships). See also 28 U.S.C.A. § 133.
} 
The final unincorporated inhabited territory, American Samoa, does not have a federal court. Matters related to federal law instead go to U.S. district courts in Hawaii or the District of Columbia. ${ }^{442}$

\section{TREATY-BASED COURTS: ARTICLES II(2)/I(8)(3) HYBRIDS}

Another category of federal court finds its origins in Article II, which grants the executive the authority "to make Treaties, provided two thirds of the Senators present concur" and to "appoint Ambassadors, other public Ministers and Consuls." 443 The power to negotiate is construed broadly and reflects long-established diplomatic practice-including providing for the establishment of federal courts overseas. As the Supreme Court explained in the 19th century, "[t]he treaty-making power vested in our government extends to all proper subjects of negotiation with foreign governments. It can, equally with any of the former or present governments of Europe, make treaties providing for the exercise of judicial authority in other countries by its officers appointed to reside therein." ${ }^{44}$ Accordingly, citizens' rights overseas, and the extent to which foreign nationals' domestic law is applied through such courts, are set by formal international agreement. So, too, are tribunals related to citizens' rights outside the United States when set against those of other countries.

Treaties are necessary but not sufficient for establishing extraterritorial courts. They depend equally upon foreign nationals' domestic law for the relevant tribunal to be brought into existence. ${ }^{45}$ In the U.S. context, all such treaties would have to be supported by Congressional statute. ${ }^{446}$ While the status of self-executing versus nonself-executing treaties is a complex area of the law, a central consideration is whether Congress needs to create legal authority for carrying out the functions and obligations in the agreement or making them enforceable in a U.S. court. ${ }^{447}$ Consular courts, as well as tribunals related to slavery and international land claims, fall within this category.

\section{A. Consular Courts}

From the earliest days of the Republic, it has been understood that when a treaty addresses an area constitutionally assigned to Congress, it cannot be used to bypass the legislature. ${ }^{448}$ Thus, lower courts have found that treaty provisions which implicate revenue or expenditures require legislative action to be given effect. ${ }^{449}$ In 1929 , the Supreme Court ruled that Congress, in creating consular courts, was acting under its commerce clause authorities. ${ }^{450}$ It had done so since the early days of the Republic.

\footnotetext{
${ }^{442}$ See U.S. Gov't AcCountability OfF., GAO-08-1124T, American SAMOA: IsSUES Associated with SOME FEDERAL Court OPTIONS 2 (2008).

${ }^{443}$ U.S. CONST. art. II, $\$ 2$, cl. 2.

${ }^{444}$ In re Ross, 140 U.S. 453, 463 (1891).

${ }^{445}$ See Dainese v. Hale, 91 U.S. 13, 15-16 (1875).

${ }^{446}$ In the case of the International Court of Justice, for instance, the Supreme Court determined that the executive could not unilaterally enforce its decisions. Medellín v. Texas, 552 U.S. 491, 525-30 (2008).

447 See id. at 530.

4485 ANNALS OF CONG. 771 (1796).

${ }^{449}$ See, e.g., Edwards v. Carter, 580 F.2d 1055 (D.C. Cir. 1978) (per curiam); The Over the Top, 5 F.2d 838, 845 (D. Conn. 1925); Swearingen v. United States, 565 F. Supp. 1019, 1022 (D. Colo. 1983).

${ }^{450}$ Ex parte Bakelite Corp., 279 U.S. 438, 451 (1929). Several courts have recognized consular court jurisdiction and appellate review as designated by statute. See, e.g., Am. China Dev. Co. v. Boyd, 148 F. 258 (C.C.N.D. Cal. 1906) (No. 13,682); Biddle v. United States, 156 F. 759 (9th Cir. 1907); Cunningham v. Rodgers, 171 F. 835 (9th Cir. 1909); Swayne \& Hoyt, Inc. v. Everett, 255 F. 71 (9th Cir.
} 
In 1792, for instance, the Second Congress passed a statute consistent with a treaty between the United States and France, giving U.S. district court judges the authority to hear cases related to shipwrecked French vessels off the coast of the United States. ${ }^{451}$ U.S. consuls and vice-consuls overseas were given the right of receiving any protests or declarations of captains, masters, crews, passengers, and merchants (as were U.S. citizens) abroad, as well as any claims from foreign persons against U.S. citizens. ${ }^{452}$ Consuls could issue decrees carrying the force of law, as would such decisions "in all courts in the United States." 453 They could manage the estates of U.S. persons who died either at sea or within their consulate. ${ }^{454}$ For their work, consuls were to be paid according to a set rate of compensation. ${ }^{455}$ These duties were "not be construed to the exclusion of others, resulting from the nature of their appointments, or any treaty or convention under which they may act." ${ }^{456}$ In 1803 and 1840, Congress passed two more statutes, detailing further powers and responsibilities. ${ }^{457}$

The system continued to develop in piecemeal fashion, with the President making consular appointments in an ad hoc manner. The number of consulates rapidly proliferated: by 1846, there were 175 consulates and commercial agencies abroad, plus three consuls to the Barbary States (in Tangiers, Tunis, and Tripoli). ${ }^{458}$ These officers tended to operate in a manner that furthered the personal interests of those in office, rather than those of the United States. ${ }^{459}$ In light of the sheer numbers, the annual expenditures, and the lack of respect afforded by other countries to the consuls' positions, James Buchanan, U.S. Secretary of State, called on Congress to reform the system. ${ }^{460}$

In 1848, Congress thus passed a fourth statute, setting out in a detailed and comprehensive manner, the responsibilities and judicial functions of foreign ministers and consuls. ${ }^{461}$ Again at the urging of the U.S. Secretary of State, just over a decade later, the Senate Committee on Foreign Relations considered a new bill to carry certain aspects of treaties with several countries into effect. ${ }^{462}$ In 1866, Congress adopted a broader statute encompassing more States, which was further amended in 1870, 1874,

1919); Fleming v. United States, 279 F. 613 (9th Cir. 1922); Wulfsohn v. Russo-Asiatic Bank, 11 F.2d 715 (9th Cir. 1926). There also may be an Article I(8)(18) claim here, consistent with Missouri v. Holland, 252 U.S. 416, 432 (1920) (holding that where a treaty was constitutional, Congress had the power under Art. I(8)(18) to enact implementing legislation without being constrained by the 10th Amendment).

${ }^{451}$ Act of Apr. 14, 1792, ch. 24, § 1, 1 Stat. 254, 254. In Moore's early 20th century account of consular law, he erroneously asserts that the first law governing consuls came in 1848. There were, however, prior to that time, two statutes passed that related to consular affairs. See 2 JOHN BASSET Moore, A Digest OF INTERNATIONAL LAW 613 (1906).

${ }^{452}$ Sec. 2, 1 Stat. at 255.

${ }^{453} \mathrm{Id}$.

${ }^{454} \mathrm{Id}$.

${ }^{455} I d . \S \S 2,4,5,1$ Stat. at 255, 255-56, 256.

${ }^{456} I d$. $\S 9,1$ Stat. at 257.

${ }^{457}$ Act of Feb. 28, 1803, ch. 9, 2 Stat. 203; Act of July 20, 1840, ch. 48, 5 Stat. 394.

${ }^{458}$ Report on Consular System, H.R. ExEC. Doc. No. 29-12 (2d Sess.), at 12 (1846).

${ }^{459}$ See id. at 2-3.

460 See id. at 2-19.

461 Act of Aug. 11, 1848, ch. 150, 9 Stat. 276.

${ }^{462}$ See Act of June 22, 1860, ch. 179, 12 Stat. 72. 
and 1876. ${ }^{463}$ These laws enabled U.S. consuls in China, Japan, Siam, Egypt, Madagascar, Turkey, Abyssinia, Persia, Tripoli, Tunis, Morocco, Muscat, the Samoan Islands, and other countries with similar treaties in place to assume judicial functions. ${ }^{464}$

In 1832, for example, a treaty between the United States and the Ottoman Empire provided,

If litigations and disputes should arise between the subjects of the Sublime Porte and the citizens of the United States, the parties shall not be heard, nor shall judgment be pronounced unless the American Dragoman be present. Causes in which the sum may exceed five hundred piastres, shall be submitted to the Sublime Porte, to be decided according to the laws of equity and justice. Citizens of the United States of America, quietly pursuing their commerce, and not being charged or convicted of any crime or offence, shall not be molested; and even when they have committed some offence ... they shall be tried by their Minister or Consul, and punished according to their offence." ${ }^{265}$

Following the dissolution of the Ottoman Empire, the treaty, along with custom and usage under the capitulatory regime in Egypt and in the former Ottoman Empire, and "the laws of the United States enacted to give effect to the treaties of the United States by virtue of which the United States was granted extraterritorial jurisdiction," formed the basis for subsequent American consular courts in Egypt. ${ }^{466}$

Under the relevant statutes establishing consular courts, ministers and consuls were provided with judicial authority ${ }^{467}$ which extended in criminal matters to trying and punishing citizens accused of offenses against U.S. law, ${ }^{468}$ and for civil matters, to "all controversies between citizens of the United States, or others" insofar as is limited by the language of the governing treaty. ${ }^{469}$ Jurisdiction is to be exercised consistent with U.S. law, or, where unsuitable or deficient, with "the common law, and the law of equity and admiralty." ${ }^{\prime 70}$ With the exception of the U.S. Court of China (discussed, below), the judges did not enjoy tenure in office. If insufficient, ministers could make decrees or regulations with the force of law, with the consuls signifying their agreement or disagreement with the regulations in writing. Statutory law empowered the minister to publish the regulation, along with advice received, and to transmit the regulation to the Secretary of State "to be laid before Congress for revision." ${ }^{471}$

\footnotetext{
${ }^{463}$ See Act of July 28, 1866, ch. 296, § 11, 14 Stat. 310, 322 (Egypt); Act of July 1, 1870, ch. 194, § 1, 16 Stat. 183, 183 (Madagascar); Act of Mar. 23, 1874, ch. 62, 18 Stat. 23; Act of Feb. 1, 1876, ch. 6, 19 Stat. 2.

${ }^{464}$ See 47 Rev. Stat. $\S \S 4083,4125-4127$ (2d ed. 1878); Act of June 14, 1878, ch. 193, 20 Stat. 131. See also 22 U.S.C. $§ 141$ (1952) (repealed Act of Aug. 1, 1956, ch. 807, 70 Stat. 773) (removing consular jurisdiction from Morocco, the last foreign country where consuls exercised such).

465 Treaty of Commerce and Navigation, Ottoman Empire-U.S., art. IV, May 7, 1830, 8 Stat. 408, 409.

${ }^{466}$ See Letter from Green H. Hackworth, Legal Advisor, Sec'y of State, to Messrs. Alexander and Green of New York (Aug. 26, 1935), reprinted in 1 Foreign Relations of THE United STATES, 1935, at 565 (E.R. Perkins \& Gustave A. Nuermberger eds., 1953), https://history.state.gov/historicaldocuments/frus1935v01/d432.

467 See 47 Rev. Stat. $\$ 4083$ (2d. ed. 1878); 22 U.S.C. §§ 141-183 (1952).

46847 Rev. Stat. § 4084. See also 22 U.S.C. $\$ 142$ (1952).

46947 Rev. Stat. § 4085. See also 22 U.S.C. $\$ 143$ (1952)

47047 Rev. Stat. $\S 4086$. See also 22 U.S.C. $\$ 145$ (1952).

47147 Rev. Stat. $§ \$ 4117-4119$.
} 
Like Article III courts, all consular courts have been courts of limited jurisdiction. ${ }^{472}$ They are limited to consular business inside their district. ${ }^{473}$ Traditionally, their functions have included legalizing acts of foreign judicial or other functionaries; authenticating citizens' marriages, births, and deaths while outside the United States; reclaiming deserters and providing for destitute sailors; receiving protests of masters of vessels; and administering the personal property of deceased citizens. ${ }^{474}$ For serious or complex matters carrying fines above $\$ 500$ or terms of imprisonment above 60 days, the consul must summon up to four citizens to participate in the adjudicatory process. ${ }^{475}$ In capital cases, the decision had to be unanimous. The judicial authority provided to consuls and ministers has been upheld by the U.S. Supreme Court. ${ }^{476}$

At times, Congress has acted to put consular courts on a more robust constitutional footing, building appeal into the Article III judicial branch. The U.S. Court for China, for instance, served as a District Court with extraterritorial jurisdiction over U.S. citizens in China. It arose out of the Treaty of Wangxia, a diplomatic agreement between the Qing dynasty and the United States in 1844, which established that U.S. citizens in China were exempt from the authority of local courts and subject, instead, to U.S. law. ${ }^{477}$ In 1860, Congress passed another statute to carry into effect a new treaty signed with China in 1858, as well as similar treaties made with Japan, Siam, Persia, and elsewhere. ${ }^{478}$ These agreements essentially formed the basis of a consular court for U.S. persons located in China.

The court operated under U.S. law and adjudicated associated matters. But, following numerous complaints, in 1906 Congress created the United States Court for China. ${ }^{479}$ It extended jurisdiction to all criminal cases carrying a punishment in excess of $\$ 100$ fine or 60 days' imprisonment, and civil cases involving claims of more than $\$ 500 .{ }^{480}$ The court served as the appellate court for the remaining consular cases and could also hear appeals from the consular court in Korea. ${ }^{481}$ Appeal from the court was first to the Ninth Circuit (District Court and then to the Circuit Court), and thence to the Supreme Court. ${ }^{482}$

The jurisdiction of the U.S. Court of China, both original and on appeal, in civil and criminal matters, was to "in all cases be exercised in conformity with said treaties and the laws of the United States." 483 Where deficient, "common law and the law as established by the decisions of the courts of the United States" applied. ${ }^{484}$ The judges of the court and the district of attorney were appointed by the President, by and with the advice and consent of the Senate, with a fixed compensation set by statute. ${ }^{485}$ The tenure

${ }^{472}$ MoORe, supra note 451 , at 628 .

${ }^{473}$ See id. at 616 (citing to 47 Rev. Stat. 4088).

${ }^{474}$ Hajime Oura, Consular Courts 1-2 (1893) (Thesis, Cornell University School of Law), https://scholarship.law.cornell.edu/cgi/viewcontent.cgi?article=1296\&context=historical_theses.

475 See 47 Rev. Stat. § 4105-4107.

${ }^{476}$ See In re Ross, 140 U.S. 453, 464 (1891); Dainese v. Hale, 91 U.S. 13, 20 (1875).

477 See Treaty of Wangxia, China-U.S., art. XXI, July 3, 1844, 8 Stat. 592, 597.

478 See Act of June 22, 1860, ch. 179, 12 Stat. 72.

479 Act of June 30, 1906, ch. 3934, 34 Stat. 814 (repealed by Treaty for Relinquishment of Extraterritorial Rights in China and the Regulation of Related Matters, China-U.S., Jan. 11, 1943, 57 Stat. 767).

${ }^{480}$ See id. $\$ \S 1-2,34$ Stat. at $814-15$.

${ }^{481} I d$. $\S 2,34$ Stat. at 815 .

482 Id. $\S 3,34$ Stat. at 815 .

${ }^{483}$ Id. $§ 4,34$ Stat. at 815 .

${ }^{484} \mathrm{Id}$.

${ }^{485}$ Id. $\S 6,34$ Stat. at 816 . 
of office was for 10 years, with removal prior to that time by the President for cause. ${ }^{486}$ The structure of the court reflected that of an ordinary District Court, replete with a Presidentially-appointed District Attorney, Marshal, and Clerk. ${ }^{487}$ The court was based in Shanghai and had sessions in Canton, Tientsin, and Hankau. ${ }^{488}$

Along with the United States, Great Britain, France, Italy, Japan, Belgium, Switzerland, Norway, Brazil, Denmark, and Sweden held extraterritorial rights in China. ${ }^{489}$ Only the United States and Great Britain, however, had independent, autonomous courts. ${ }^{490}$ In every case, the threshold question for judicial proceedings was the citizenship of the defendant, for while any plaintiff could raise an issue, as long as the defendant was a national of the country in question, they had the right to proceedings in their own consular court. ${ }^{491}$ In 1921, the court ruled that the U.S. Constitution did not apply in China. ${ }^{492}$ As a practical matter, this meant no trial by jury, although, according to a judge on the court, "the Bill of Rights was otherwise scrupulously respected as a matter of primary American principle and legal policy." 493

The act creating the United States Court of China was not without its criticsincluding the Secretary of State Elihu Root, who roundly denounced it. ${ }^{494}$ Not least among the concerns was the difficulty of determining what constituted "the laws of the United States," as referenced in the governing statutes. ${ }^{495}$ Congress, moreover, provided the tribunal with jurisdiction in all cases where jurisdiction had previously been exercised by consuls and ministers. Where consular legislation fell short, the court was to look to "the common law as established by the decisions of the courts of the United States." ${ }^{496}$ With 45 sovereign states at the time, plus some territories, it was difficult to say precisely what this meant, and it mattered: most of the court's proceedings focused on criminal matters, issues related to commerce, or decedents' estates - issues largely addressed at a state level..$^{497}$ In 1907, the Ninth Circuit Court of Appeals looked to both the District of Columbia and to Alaska, as well as to 30 Geo. 2 c. 24 (1757) —which entered into common law before the United States even became a country - to reach a conclusion. ${ }^{498}$ According to Milton J. Helmick, who served as a judge 1934-43, the court subsequently "toyed for a time with the Alaska Code" before deciding to ground its jurisprudence in the laws adopted by the District of Columbia. ${ }^{499}$

During the Second Sino-Japanese War and World War II, Japan invaded and occupied Shanghai ${ }^{500}$ Following the attack on Pearl Harbor in 1941, the U.S. declared

\footnotetext{
${ }^{486} I d . \S 7,34$ Stat. at 816 .

${ }^{487} I d . \S 6,34$ Stat. at 816 .

${ }^{488} I d . \S 1,34$ Stat. at 814 .

${ }^{489}$ Milton J. Helmick, United States Court for China, 14 FAR E. SURV. 252, 252 (1945).

${ }^{490} \mathrm{Id}$.

491 See, e.g., Wulfsohn v. Russo-Asiatic Bank, 11 F.2d 715, 717-18 (9th Cir. 1926); Husar v. United

States, 26 F.2d 847, 849-51 (9th Cir. 1928).

${ }^{492}$ See United States v. Furbush, 2 Extraterr. Cas. 73, $82-85$ (U.S. Ct. China 1921) (citing and quoting In re Ross, 140 U.S. 453, 464 (1891)) ("The Constitution can have no operation in another country.")

${ }^{493}$ Helmick, supra note 489, at 254.

${ }^{494} I d$. at 253.

495 See, e.g., Note, United States Court for China, 49 HARv. L. REv. 793, 794 (1936).

496 Act of June 30, 1906, ch. 3934, § 4, 34 Stat. 814, 815.

${ }^{497}$ Note, supra note 495 , at 794.

498 See Biddle v. United States, 156 F. 759, 761-63 (9th Cir. 1907).

${ }^{499}$ Helmick, supra note 489, at 253.

${ }^{500}$ See, e.g., Eds. of Encyc. Britannica, Second Sino-Japanese War: 1937-1945, BRITANNICA, https://www.britannica.com/event/Second-Sino-Japanese-War (Nov. 10, 2020).
} 
war on Japan, prompting the latter to end concessions for Americans in Shanghai and to imprison the judges of the court. In 1943, the United States signed a treaty with China that gave up any extraterritorial rights and abolished the court. ${ }^{501}$ Five years later, Congress formally repealed the statutory provisions. ${ }^{502}$

The U.S. Court for China provides special study in consular courts, as it is the only one for whom appeal has been directly to an Article III court and whose judges have enjoyed fixed terms (as aforementioned, 10 years). In 1956, Congress repealed its final remaining extraterritorial privilege (in Morocco), thus ending the operation of federal consular courts. ${ }^{503}$

\section{B. Slavery and Land Claims}

In addition to the traditional consular courts, Congress has established other courts to implement treaty arrangements. In 1862, for example, the United States and Great Britain agreed to take mutual steps to suppress the slave trade. ${ }^{504}$ Once again, Congress's power to legislate arose from Art. I(8)(3). The countries agreed that if either country discovered a ship of the other country carrying slaves on the high seas, the cargo would be subject to forfeiture proceeds before mixed claims courts, which would be established by the two countries. ${ }^{505}$ There was no appeal from these courts. ${ }^{506}$ The court was abolished in $1870 . .^{507}$

Pari passu, following the Mexican-American War, the Treaty of GuadalupeHidalgo required that the United States would respect land ownership rights established by the Mexican government. ${ }^{508}$ During ratification, the Senate struck the provisions; however, the United States assured Mexico that the land rights would be respected. ${ }^{509}$ Following the failure of a number of land commissions established to survey the newlyacquired territory, in 1891 Congress created the Court of Private Land Claims. ${ }^{510}$ Five judges, appointed by the President with the advice and consent of the Senate, held five year terms, with appeal from the court directly to the U.S. Supreme Court. Although it was originally designed to complete its task in five years, the Court of Private Land

\footnotetext{
501 Treaty for Relinquishment of Extraterritorial Rights in China and the Regulation of Related Matters, China-U.S., Jan. 11, 1943, 57 Stat. 767

${ }^{502}$ See Judiciary and Judicial Procedure, ch. 646, § 39, 62 Stat. 869, 992 (1948). For further discussion of the U.S. Court for China, see Teemu Ruskola, Colonialism Without Colonies: On the Extraterritorial Jurisprudence of the U.S. Court for China, 71 LAW \& CONTEMP. PROBS. 217 (2008).

${ }^{503}$ Act of Aug. 1, 1956, ch. 807, 70 Stat. 773.

${ }^{504}$ Treaty for the Suppression of the African Slave Trade (Treaty of Washington), Gr. Brit.-U.S., art. IV, Apr. 7, 1862, 12 Stat. 1225, 1227 (amended by Additional Article to the Treaty for Suppression of the African Slave Trade, Gr. Brit.-U.S., Feb. 17, 1863, 13 Stat. 645); Act of July 11, 1862, ch. 140, 12 Stat. 531 (authorizing the President to nominate a judge to the court).

${ }^{505}$ Art. IV, 12 Stat. at 1227.

${ }^{506} I d$.

${ }^{507}$ See Additional Convention to Convention Respecting the African Slave Trade, Gr. Brit.-U.S., June 3, 1870, 16 Stat. 777.

${ }^{508}$ See Treaty of Peace, Friendship, Limits, and Settlement Between the United States of America and the United Mexican States (Treaty of Guadalupe Hidalgo), Mex.-U.S., arts. VIII-X, Feb. 2, 1848, 9 Stat. 922 , 929-30. See also Treaty of Mexico City, Mex.-U.S., art. V, Dec. 30, 1853, 10 Stat. 1031, 1035.

509 Court of Private Land Claims, 1891-1904, FED. JuD. CTR., https://www.fjc.gov/history/courts/courtprivate-land-claims-1891-1904 (last visited Jan. 15, 2021).

510 Act of Mar. 8, 1891, ch. 539, 26 Stat. 854 1891. See also Wilber Griffith Katz, Federal Legislative Courts, 43 Harv. L. Rev. 894, 907-08 (1930).
} 
Claims continued for thirteen years, in the course of which it ruled on title to more than 35 million acres of land. ${ }^{511}$

\section{COURTS OF OCCUPATION: ARTICLE II(1)}

Like the courts addressed in Parts II-V, above, Article II courts derive from the Constitution. But unlike Article III(1), I(8), and IV(3) entities, or Article II(2)/I(8)(3) hybrids, pure Article II(1) courts of occupation do not require Congressional action prior to being brought into being. They are created solely at the behest of the Executive. Driven by duties entrusted to commissioned officers, they adhere to the Executive as an aspect of conquest and expansion. They are unique to (1) land purchases prior to Congressional establishment of territorial government, (2) armed rebellion, and (3) war with foreign powers.

As a matter of Constitutional grounding, Article II(1), which establishes the President as Commander in Chief of the Army and Navy, provides the primary locus. ${ }^{512}$ To some extent, the authority for their creation can also be said to adhere to the executive by nature of the sovereignty of the United States: occupation courts may be integral to national integrity or to U.S. efforts to treat or to prosecute war with foreign powers. ${ }^{513}$ Over the course of U.S. history, at least a dozen such entities have been established, generally — but not solely - in the shadow of war. ${ }^{514}$ While most pre-date the Civil War, at least four operated in the 20th century. ${ }^{515}$ In addition to the more established occupation courts, numerous additional Article II(1) tribunals operated during the U.S. Civil War on an informal basis, with little or no record of their proceedings. ${ }^{516}$ Some are referred to as "provost courts," because provost marshals, who handle law enforcement matters within the military, serve as judges ${ }^{517}$ Others are created, and jurists appointed, at the direction of the individual responsible for governance of the region. Yet others are a form of military commission that do not rely on any, specific Congressional statute for their operation.

\section{A. Land Acquisition}

As an historical matter, some have been created as an interim step, prior to Congressional establishment of territorial government. For example, following the retrocession of what was to become the Louisiana territory from Spain to France, and Napoleon Bonaparte's accession, President Thomas Jefferson used the impending war between Great Britain and France to negotiate the transfer of the French land in North America to the United States. As part of the Louisiana Purchase, the offices of alcaldes, who served as judges in criminal cases in Spanish audiencias, were abolished, leaving no one vested with judicial authority. Accordingly, one of Governor William Claiborne's first actions in New-Orleans was to create a court of pleas, consisting of

511 Court of Private Land Claims, 1891-1904, supra note 509.

${ }^{512}$ U.S. CONST. art. II, § 2, cl. 1.

${ }^{513}$ See United States v. Curtiss-Wright Exp. Corp., 299 U.S. 304, 318 (1936).

${ }^{514}$ See ThomAs, supra note 6, at 38-39, 63, 103-05, 230-31, 281, 282, 296-98, 303, 304, 312-13, and

317-18.

${ }^{515}$ Bederman, supra note 6 , at 826.

516 See e.g., id. at 839-40; 2 FrançOIS-XAVIER Martin, The History OF Louisiana, From the EARLiest PERIOD 238-39 (New Orleans, A.T. Penniman, \& Co. 1829).

${ }^{517}$ Bederman, supra note 6 , at 840 . 
seven jurists with jurisdiction over certain civil and criminal matters. ${ }^{518}$ The court could hear civil cases up to $\$ 3,000$, with appeal for anything over $\$ 500$ directly to the governor ${ }^{519}$ For criminal matters, the court had jurisdiction over all offenses for which the punishment did not exceed 60 days' imprisonment and a fine of $\$ 200 .{ }^{520}$ Anything less than $\$ 100$ could be decided by an individual jurist, with appeal to the court of pleas. ${ }^{521}$

\section{B. Armed Rebellion}

Article II(I) courts also have been established in regions marked by violent civil unrest and armed rebellion. Examples present both early on in U.S. history as well as during the Civil War. While the courts established during the latter period bear many hallmarks of military commissions in that they are constituted by the military and try civilian violations of law, they can be distinguished from Article I(8)(10) and (11) entities as a matter of process and substance. First, unlike the case with military commissions, there is no explicit Congressional authorization for their creation. Instead, they are informally created - and disbanded - at the will of military commanders. Second, unlike military commissions, no declaration of war undergirds their formation. Third, they introduce laws and rules outside of any action by a legislature that represents those to whom the laws apply. Fourth, they purport to govern people within their locality - that is, their jurisdiction extends to both military personnel and civilians within a specified area.

Such courts have operated from the earliest days of the Republic. Recall that during the Revolutionary War the colonies of East and West Florida stayed loyal to the Crown. ${ }^{52}$ The 1783 Treaty of Paris returned them to Spain. ${ }^{523}$ In 1810, the settlers in West Florida rebelled and declared independence. ${ }^{524}$ President James Madison asserted that the portions of West Florida from the Mississippi to the Perdido rivers had been acquired as part of the Louisiana Purchase, and negotiations commenced with Spain. ${ }^{525}$

In Spanish-controlled Florida, Seminole attacks within U.S. territories in late 1817 and 1818 led to the creation of occupation courts. In January 1818, Major James Bankhead, the commanding officer in Fernandina (located on Amelia Island-and now the northernmost city on the coast of Florida), issued an ordinance applying U.S. law and installing two justices of the peace, to issue final decisions in cases involving claims up to one hundred dollars. ${ }^{526}$ The justices were to investigate criminal cases and to

${ }^{518} I d$.

${ }^{519}$ MARTIN, supra 516, at 238-239.

${ }^{520} I d$. at 239.

${ }^{521} \mathrm{Id}$.

${ }^{522}$ Acquisition of Florida: Treaty of Adams-Onis (1819) and Transcontinental Treaty (1821), OFF. OF THE HISTORIAN, https://history.state.gov/milestones/1801-

1829/florida\#: :text=NOTE\%20TO\%20READERS-

,Acquisition\%20of\%20Florida\%3A\%20Treaty\%20of\%20Adams\%2DOnis\%20(1819), they\%20returned $\% 20$ to\%20Spanish\%20control (last visited Jan. 7, 2021).

${ }^{523}$ See id.; Definitive Treaty of Peace (Treaty of Paris), Gr. Brit.-U.S., art. II. Sept. 3, 1783, 8 Stat. 80, 81-82.

${ }^{524}$ Acquisition of Florida, supra note 522.

${ }^{525} \mathrm{Id}$.

${ }^{526}$ See Message from the President Transmitting Information Relative to the Occupancy of Amelia Island, St. Marks, and Pensacola, H.R. EXEC. Doc. No. 15-117 (2d Sess.), at 9 (1819) (extract of a letter from Major James Bankhead to J.C. Calhoun, Sec'y of War, Jan. 10, 1818), 10 (ordinance issued Jan. 5, 1818). 
forward their opinions to the commanding officer, who had final authority in cases affecting the life of the accused. ${ }^{527}$ To the commanding officer fell "all cases of riot, or other disorders that may affect the peace and security" of the island. ${ }^{528}$ As a matter of procedure, "[i]n all cases, particularly in matters of evidence, the usages and customs of the United States" applied. ${ }^{529}$ At that point, conditions of war and unrest existed in the territory, prompting John C. Calhoun, Secretary of War, to support stringent measures. ${ }^{530}$ Simultaneously, General Andrew Jackson pushed for U.S. invasion and control of Pensacola - a goal accomplished in May 1818. ${ }^{531}$ Following conquest, in February 1819, Spain agreed to cede the Floridas to the United States ${ }^{532}$ Congress did not ratify the Adam-Onis Treaty until $1821 .{ }^{533}$

In the interim, military officers immediately assumed the duties of civil magistrates. The commission appointing the first governor, authorized Jackson "to exercise . . . all the powers and authorities heretofore exercised by the Governor and Captain General and Intendant of Cuba, and by the Governors of East and West Florida, within the said provinces, respectively." ${ }^{334}$ Jackson, accordingly, issued an order establishing county courts comprised of five justices of the peace each. ${ }^{535}$ For civil cases, Spanish law applied (outside of witness examination), while in criminal matters common law applied. ${ }^{536}$ Premised on an indictment by a grand jury issued in the name of the United States, the criminal trials themselves were public and held before a petit jury. ${ }^{537}$ Five days after the first order establishing the court, the governor issued another ordinance detailing the court's rules of procedure and setting compensation rates for judicial officers. ${ }^{538}$ The commissions for judges in West Florida were subsequently issued by Secretary Adams. ${ }^{539}$

During the Civil War, myriad occupation courts similarly emerged as the Union brought different regions under control. The authority to convene such tribunals depended on rank - not on any particular appointment to the court. ${ }^{540}$ Many of these courts were so informal that essentially no records of their proceedings are left. ${ }^{541}$ They exercised criminal and, at times, civil jurisdiction. With no Congressional declaration of war, or legislative framing for the courts or the rules they executed, these tribunals arose solely at the behest of the executive. Applied to civilians in specified areas, they

527 Id. at 10 .

${ }^{528} \mathrm{Id}$.

${ }^{529} \mathrm{Id}$.

${ }^{530}$ See id. at 11-17 (detailing armed conflict).

${ }^{531}$ General Jackson Invades Spanish Territory and Takes Pensacola, Hist. EnGINE, https://historyengine.richmond.edu/episodes/view/2329 (last visited Jan. 7, 2021).

532 THOMAS, supra note 6, at 65-66.

${ }^{533} \mathrm{Id}$. at 65.

${ }^{534}$ Special Commission to Major General Andrew Jackson for Carrying into Effect the Stipulations of the Treaty (Mar. 20, 1821), 4 AMERICAN STATE PAPERS: FoREIGN RELATIONS 752 (Walter Lowrie \& Walter S. Franklin eds., Washington, Gales \& Seaton 1834).

53539 ANNALS OF CONG. 2551 (1822).

${ }^{536} \mathrm{Id}$. at $2551-52$.

${ }^{537} \mathrm{Id}$. at 2552.

53839 ANNALS OF CONG. 2553-56 (1822).

539 See ThOMAs, supra note 6, at 272.

${ }^{540}$ Bureau of Mil. Just., War DeP'T, Digest of Opinions of the Judge Advocate General of the ARMY 34 (Washington, Government Printing Office 1866), https://www.loc.gov/law/mlr/Lieber_Collection-pdf/Digest-of-Opinions-JAGArmy.pdf

${ }^{541}$ See Bederman, supra note 6, at 840 n.73 (citing and quoting Provisional Judiciary of Louisiana, 13 AM. L. ReG. 257, 259 (1865)). 
tried violations of law as defined by the occupying powers - an approach consistent with traditional laws of war.

In 1862, for instance, multiple such courts marked New Orleans and its surrounds. ${ }^{542}$ Immediately following capture of the city, Union forces established a provost marshal's court. ${ }^{543}$ It initially focused on more traditional matters related to courts-martial matters: servicemembers and the laws of war. Soon, however, its jurisdiction extended into the civilian realm to all criminal matters and most civil causes. ${ }^{544}$ The military also revived former parish courts in the region. ${ }^{545}$ Many of the judges had left prior to occupation, requiring Union forces to install new jurists. ${ }^{546}$ Some civil courts, in addition, resumed operating in November 1862, with jurisdiction limited to defendants in the parish of Orleans. ${ }^{547}$

All of these were local courts. To address the absence of any federal entities, President Abraham Lincoln further created the United States Provisional Court for the State of Louisiana. His authority to do so grew directly from the state of unrest that marked the region. He explained, "The insurrection which has for some time prevailed in several of the States of this Union, including Louisiana, [has] temporarily subverted and swept away the civil institutions of that State, including the judiciary and the judicial authorities of the Union." 548 This made it "indispensably necessary" to establish "some judicial tribunal . . . capable of administering justice." ${ }^{549}$ Lincoln's Executive Order establishing the court gave the judge sweeping authority

to hear, try, and determine all causes, civil and criminal, including causes in law, equity, revenue, and admiralty, and particularly all such powers and jurisdiction as belong to the District and Circuit courts of the United States, conforming his proceedings so far as possible to the course of proceedings and practice which has been customary in the courts of the United States and Louisiana; his judgment to be final and conclusive. ${ }^{550}$

The language indicated that the court would address all matters, both state and federal. Lincoln went on to empower the judge "to make and establish such rules and regulations as may be necessary for the exercise of his jurisdiction" and to empower him "to appoint a prosecuting attorney, marshal, and clerk." ${ }^{551}$ Appointment was at the pleasure of the President and was limited to military occupation of the city of New Orleans and the state. ${ }^{552}$ The court was to serve in an appellate capacity for civil cases outside of the parish of Orleans. Throughout this time, Louisiana courts continued to operate behind Confederate lines. To remedy the conflict, the judge of the Provisional Court merely

542 Id. at 841 .

${ }^{543} \mathrm{Id}$.

${ }^{544} I d$.

${ }^{545} \mathrm{Id}$.

${ }^{546} \mathrm{Id}$.

${ }^{547} \mathrm{Id}$.

${ }^{548}$ Exec. Order Establishing a Provisional Court in Louisiana (Oct. 20, 1862),

https://www.presidency.ucsb.edu/documents/executive-order-establishing-provisional-court-louisiana.

See also Burke v. Miltenberger, 86 U.S. (19 Wall.) 519, 519 (quoting the Executive Order).

${ }^{549}$ Burke, 86 U.S. at 519.

${ }^{550}$ Id. at 519-20.

${ }^{551} I d$. at 520 .

${ }^{552} \mathrm{Id}$. 
ordered that all cases in confederate courts be brought before his court. ${ }^{553}$ Soon thereafter, the military governor in the occupied region issued an order constituting a new state Supreme Court. ${ }^{554}$

Similar courts have been created in other occupied areas, such as the Philippine Islands, which the military ruled from the capture of Manila in 1898 until Congress created a statutory framing in $1902 .{ }^{555}$ Similar experiences mark U.S. actions in Cuba and Puerto Rico. ${ }^{556}$ As the Supreme Court of Tennessee observed in Rutledge v. Fogg, a case upholding the decisions of a military occupation tribunal convened in Memphis, Tennessee by a Union general, the right of a country to occupy and govern the territory of another while in military possession of it flows from the fact of conquest and the laws of war. ${ }^{557}$

The most recent example of the establishment of Article II courts in the midst of armed rebellion and violence in U.S. territory is the imposition of martial law in Hawaii during World War II. The Organic Act for the territory empowered the governor, "in case of rebellion or invasion, or imminent danger thereof, when the public safety requires it," to "suspend the privilege of the writ of habeas corpus, or place the Territory or any part thereof, under martial law until communication can be had with the President." ${ }^{558}$ On December 7, 1941, Joseph Poindexter, the civilian territorial governor, responded to the Pearl Harbor bombings by suspending the writ of habeas corpus and relinquishing control of the territory to the U.S. Army commanding general, Walter C. Short. ${ }^{559}$ For nearly three years, the civilian government was suspended. Throughout that time, military courts operated. ${ }^{560}$ The Supreme Court later determined that the provisions in the Organic Act that allowed for imposition of military rule did not empower the armed forces to supplant all civilian laws when civilian government could continue to function. ${ }^{561}$ "Courts and their procedural safeguards," the Court wrote, "are indispensable to our system of government. They were set up by our founders to protect the liberties they valued." 562 As the system embraced "the antithesis of total military rule," the Court had no choice but to reject summary criminal trials by military tribunals. The boundary between military and civilian power had to be carefully maintained. ${ }^{563}$

\section{War with Foreign Powers}

War with foreign powers provides a third context for the introduction of Article II(1) tribunals. Occupation courts in this instance must comport with the law of conquest, which (as a matter of international law) requires that conquering powers, to the extent practicable, respect local custom and laws. Accordingly, in anticipation of assimilating regions into the United States, the executive has consistently upheld local

${ }^{553}$ Bederman, supra note 6 , at $842-43$.

${ }^{554} \mathrm{Id}$. at 843.

555 See Thomas, supra note 6, at 282-303; Act of July 1, 1902, ch. 1369, 32 Stat. 691.

556 See William E. Birkhimer, Military Government and Martial LaW 62-63 (3d rev. ed. 1914).

${ }^{557}$ Rutledge v. Fogg, 4. Tenn. 554, 559-61 (Tenn. 1866).

558 Act of Apr. 30, 1900, ch. 339, § 67, 31 Stat. 141, .

${ }^{559}$ HARry N. Scheiber \& Jane L. Scheiber, Bayonets in PARAdise: Martial Law in Hawai'i During WORLD WAR II, at 2 (2016).

${ }^{560} \mathrm{Id}$.

${ }^{561}$ Duncan v. Kahanamoku, 327 U.S. 304, 324 (1946).

${ }^{562} I d$. at 322.

${ }^{563} \mathrm{Id}$. 
custom in the operation of occupation courts, modifying local rules and procedures to the extent necessary to comport with U.S. constitutional norms.

The war between the United States and Mexico, declared in May 1846, for instance, led to the establishment of Article II(1) occupation courts in New Mexico. ${ }^{564}$ These tribunals derived from the President's commander-in-chief authorities: Colonel (and later Brigadier-General) Stephen W. Kearny's orders, issued June 3, 1846, showed the creation of the courts as an aspect of the military command and control process. ${ }^{565}$ While eventually Congress might act to establish a civil territorial administration, in the interim, the military was to create a government replete with judicial functions. ${ }^{566}$

The Kearny Code as implemented subsequently drew heavily from the Organic Law provided for governing the Missouri Territory-reflecting the preparation of the document by Colonel A.W. Doniphan, of the first regiment of Missouri mounted volunteers. ${ }^{567}$ The judicial structure consisted of a superior (appellate) court, constituted by three judges, and a number of lower (circuit) courts. ${ }^{568}$ The latter had jurisdiction over all criminal cases not otherwise provided by law, and "exclusive original jurisdiction in all civil cases that were not cognizable before the prefects and alcaldes." 569 The U.S. Supreme Court recognized the validity of the system as it operated until the territorial legislature explicitly adopted the orders and laws of the provisional government, as well as the judicial decisions rendered by its courts. ${ }^{570}$

In the missive of June 1846, the President similarly directed General Kearny to gain control in California. ${ }^{571} \mathrm{He}$ was to work in concert with U.S. naval forces in the Pacific to conquer the territory. ${ }^{572}$ As in New Mexico, the President instructed him to establish civil government, leaving much to his discretion in doing so, such as "best to conciliate the inhabitants, and render them friendly to the United States." ${ }^{573}$ In reflection of Kearny's new responsibilities, W.L. Marcy, Secretary of War, conveyed a promotion in rank upon him, to that of brevet brigadier general, as soon as he set forth for California. ${ }^{574}$

In 1847, Commodore James Biddle, the naval commander in Monterey, created a court to rule on prize vessels captured on the high sea. ${ }^{575}$ With the agreement of the military governor of California, and (later) explicit Presidential authorization, Biddle named a navy chaplain as judge. ${ }^{576}$ For matters on land, special tribunals were similarly constituted, such as a court formed in 1847 in Sonoma to address criminal charges

${ }^{564}$ See Occupation of Mexican Territory, H.R. ExEC. Doc. No. 29-19 (2d Sess.) (1846).

${ }^{565} \mathrm{Id}$. at 6.

566 See id.

${ }^{567}$ Assisted by Private Willard P. Hall, the final version looked strikingly similar to the copy of the Missouri statutes that Private Hall, an attorney, carried with him. See Matthew E. Stanley, Hall, Willard Preble, Civ. WAR ON THE W. BORDER, https://civilwaronthewesternborder.org/encyclopedia/hall-willardpreble (last visited Jan. 7, 2021).

${ }^{568}$ Leitensdorfer v. Webb, 61 U.S. (20 How.) 176, 178 (1857).

${ }^{569} I d$.

${ }^{570} \mathrm{Id}$.

${ }^{571}$ H.R. EXEC. Doc. No. 29-19 (2d Sess.), at 5 (1846).

${ }^{572} I d$. at 6.

${ }^{573} I d$.

${ }^{574}$ Id. at 7.

575 Jecker v. Montgomery, 54 U.S. (13 How.) 498, 512 (1851). See also Fay v. Montgomery, 8 F. Cas. 1112, 1113 (C.C.D. Mass. 1852) (No. 4709).

576 Jecker, 54 U.S. at 512. 
regarding the murder and kidnaping of Native Americans. ${ }^{577}$ The following year, a similar court convened at Monterey. ${ }^{578}$ Absent a court of appeal, the governor occasionally heard appellants. How they were treated, though, varied by the governor in question: Governor Richard Mason, who served as the fifth military governor of California, generally refused to hear an appeal if the case had already come before a jury, whereas General Bennett Riley, who commanded the Military Department in Upper California and acted as Provincial Governor 1849-50, in at least some cases ordered a stay in execution until a higher court could be convened. ${ }^{579}$

The creation of these courts was considered an integral part of the prosecution of war. ${ }^{580}$ During President James K. Polk's annual message to Congress recognized the United States' "undisputed occupation" of New Mexico and the Californias, "all resistance on the part of Mexico having ceased within their limits." ${ }^{581} \mathrm{He}$ argued for their assimilation into the United States and called on Congress to establish territorial governments as quickly as practicable over them. ${ }^{582}$ In the interim, the land was to be "governed by our military and naval commanders under the general authority which is conferred upon a conqueror by the laws of war." 583 During the subsequent debates in Congress, members recognized the President's plenary power to govern conquered territory, subject only to international law: the Constitution did not apply to land outside the United States. ${ }^{584}$

Article II(1) occupation courts do not just mark North American territory formerly held by France, Spain, or Mexico. In the aftermath of World War II, for instance, three courts were created to conduct matters in Germany and Japan. Under Law No. 2, the United States suspended the German courts in the zone that it occupied, replacing them with Military Government Courts. ${ }^{585}$ The Military Government asserted the authority to dismiss or suspend any German judge or court official, to disbar any notary or lawyer, to supervise and observe all judicial proceedings, to access all court documents and records, to review all decisions of trial and appellate courts, and to nullify, suspend, or modify any determination rendered by the courts. ${ }^{586}$ The occupation courts were constituted by summary courts (for penalties of up to 1 year's imprisonment and fines up to $\$ 1,000$ ), intermediate courts (for penalties of up to 10 years' imprisonment and fines not exceeding $\$ 10,000$ ), and general courts (for penalties of any lawful sentence, including capital cases). ${ }^{587}$ Their jurisdiction extended to all offenses committed by non-

\footnotetext{
577 ThOMAS, supra note 6, at 231.

${ }^{578} I d$.

${ }^{579}$ See H.R. EXEC. Doc. No. 31-17 (1st Sess.), at 391, 681, and 770 (1850).

${ }^{580}$ See James K. Polk, President, Third Annual Message to Congress (Dec. 7, 1847), https://millercenter.org/the-presidency/presidential-speeches/december-7-1847-third-annual-message. ${ }^{581} I d$.

$582 \mathrm{Id}$.

${ }^{583} I d$.

${ }^{584}$ See, e.g., Cong. GlobE, 29th Cong., 2d Sess. 15 (1844) (comments of Rep. Robert Barnwell Rhett (South Carolina)), 23 (comments of Rep. James Alexander Seddon (Virginia)).

${ }^{585}$ Germany Supreme Commander's Area of Control Law No. 2, German Courts, arts. I-II, MiL. Gov'T GAZETTE, Ger., U.S. Zone, no. A, June 1, 1946, at 7, 7-8, https://portal.dnb.de/bookviewer/view/1026623324\#page/7/mode/1up; Germany's Supreme Commander's Area of Control Proclamation No. 1, art. II, id. at 1.

586 Law No. 2, art. VII, at 9-10.

587 Eli E. Nobleman, Military Government Courts in Germany, 267 AnNALS AM. ACAD. PoL. \& Soc. SCI. 87, 88. For further discussion of the Military Government Court, see Eli E. Nobleman, Note, American Military Government Courts in Germany, 40 AM. J. InT'L L. 803 (1946).
} 
military personnel in the occupied area, trying matters linked to both German law and legislation passed by the military government. ${ }^{588}$

The Rules of Practice for Military Government Courts reflected Anglo-American, German, and courts-martial practices. All persons arrested were to be brought as soon as practicable before a tribunal and apprised of the charges. ${ }^{589}$ During trial, defendants could cross-examine witnesses and present their case. ${ }^{500}$ Certain fundamental rights, mirroring those laid out in the U.S. constitution, would be afforded to defendants. ${ }^{591}$ The courts had exclusive criminal jurisdiction. ${ }^{592}$

The U.S. also created a Military Government Court for Civil Actions, consisting of three members of the bar in good standing in one of the states or territories or the District of Columbia of the United States. ${ }^{53}$ In 1949, the United States Courts of the Allied High commission, operated by the U.S. State Department, replaced the Military Government tribunals with civilian jurists. ${ }^{594}$ In addition to criminal matters, the court addressed all cases in which servicemembers or their dependents, or civilian officials, were a party. ${ }^{595}$ These tribunals ended with the transfer of sovereignty to the Federal Republic of Germany (West Germany). ${ }^{596}$ However, the United States maintained an occupation regime within West Berlin. ${ }^{597}$ Thus, the United States Court for Berlin was established in $1955 .{ }^{598}$ By the time it was abolished in 1990 , however, it had only heard one case. ${ }^{599}$

The Treaty of Peace with Japan authorized the United States to exercise jurisdiction over certain Japanese territories. ${ }^{600}$ In 1957, President Eisenhower issued an Executive Order providing for a judicial system in the Ryukyu Islands modeled after that employed in Puerto Rico. ${ }^{601}$ It provided for a local court with general jurisdiction over civil matters and criminal jurisdiction related to Ryukyuans, as well as a second, Civil Administration Court system, with trial and appellate tribunals. ${ }^{602}$ These entities had authority over any case or controversy impacting U.S. property or interests, as well as cases to which U.S. persons were party ${ }^{603}$ The U.S. relinquished control of the Ryukyu Islands in $1972 .{ }^{604}$

\footnotetext{
${ }^{588}$ Nobleman, supra note 587, at 88.

${ }^{589}$ Rules of Practice in Military Government Courts, Extract, Rule 6(1), Mil. Gov'T GaZeTte, GeR., U.S. Zone, no. A, June 1, 1946, at 63, 64.

${ }^{590}$ Rule 10(1), id. at 65-66.

${ }^{591}$ See id. at 63-71.

${ }^{592}$ Bederman, supra note 6 , at 846.

${ }^{593}$ Ordinance No. 6, Military Government Court for Civil Actions, Mil. Gov'T GazeTte, Ger., U.S.

ZONE, no. A, June 1, 1946, at 73.

${ }^{594}$ Bederman, supra note 6 , at 846.

${ }^{595} \mathrm{Id}$.

${ }^{596} I d$.

${ }^{597}$ See id.

${ }^{598}$ U.S. High Comm'r for Ger. Law No. 46, Apr. 28, 1955, reprinted in Unite States v. Tiede, 86 F.R.D. 227, 261-65 (U.S. Ct. Berlin 1979).

${ }^{599}$ United States v. Tiede, 86 F.R.D. 227, 237 (U.S. Ct. Berlin 1979) (noting that the court was

"established pursuant to powers granted to the President by Article II of the Constitution"). See also Bederman, supra note 6, at 846-47.

${ }^{600}$ Treaty of Peace with Japan (Treaty of San Francisco), art. 3, Apr. 28, 1952, 3 U.S.T. 3169, 3172-73.

${ }^{601}$ Exec. Order No. 10,713, § 10, 3 C.F.R. 68, 70-71 (Supp. 1957).

${ }^{602} \mathrm{Id}$.

${ }^{603} \mathrm{Id}$.

${ }^{604}$ Agreement Between the United States of America and Japan Concerning the Ryukyu Islands and Daito Islands, Japan-U.S., June 17, 1971, 23 U.S.T. 447 (entered into force May 15, 1972).
} 


\section{ADMINISTRATIVE ADJUDICATION}

Administrative agencies house several adjudicatory bodies that are not considered part of the federal judicial system. They are distinguished by the degree of independence that they have from even the Executive. Their existence derives in significant measure from the Progressive Era and the rapid proliferation of the administrative state. ${ }^{605}$ It would be impossible to summarize all such entities: as of March 2017, more than 1,900 administrative law judges (ALJs) were serving in at least 27 adjudicatory bodies, with their specific roles and responsibilities reflecting those of the agencies and departments in which they were located. ${ }^{606}$

The largest of these entities, which rivals the size of the Bankrupcy Courts, is the Social Security Administration (SSA), which houses nearly 85 percent of all ALJs. ${ }^{607}$ The SSA annually processes over 650,000 decisions at the hearing level. ${ }^{608}$ Like the SSA, most administrative agency tribunals hold hearings, issue decisions or make recommendations, and enforce agency regulations. ${ }^{609}$ Many of these decisions are reviewable within an appellate structure within the agency, such as the SSA's Appeals Council. Often, the reviewing body consists of administrative appeals judges (AAJs). ${ }^{610}$

Similarly, by statute, the U.S. Tax court "is not an agency of, and shall be independent of, the executive branch." ${ }^{11}$ The line between the quasi-judicial functions often undertaken by administrative agencies and the judicial matters that come before Article I or Article III courts, though, is not always clear. In 1932, for example, the Court allowed a private right (workers' compensation) to be heard by an agency, while still trying to preserve Article III courts' role in determining questions of law, as well as certain matters of fact. ${ }^{612}$ This case played a central role in the growth of the administrative agencies. ${ }^{613}$

Entities discussed in Part III, above (i.e., specialized Article I(8) courts), are (a) statutorily named a court of record; (b) explicitly established under Article I by statute; or (c) stated by the Supreme Court or by the reviewing appellate court as being an Article I court. In contrast, administrative tribunals do not fit any of these categories. ${ }^{614}$

605 Executive Agency Courts, FED. JUD. CTR., https://www.fjc.gov/history/courts/executive-agency-courts (last visited Jan. 8, 2021).

${ }^{606}$ See ALJs by Agency, OPM.gov, https://www.opm.gov/services-for-agencies/administrative-lawjudges/\#url=ALJs-by-Agency (last visited Jan. 8, 2021).

${ }^{607}$ ALJS by Agency, supra note 606 (indicating that 1,655 of the 1,931 ALJs are attached to the Social Security Administration).

${ }^{608}$ Information About SSA's Hearings and Appeals Operations, SSA.gov, https://www.ssa.gov/appeals/about_us.html (last visited Jan. 8, 2021). The only Article I or III judicial body that sees more cases per year are the Bankruptcy Courts. Federal Judicial Caseload Statistics 2019, U.S. CTS., https://www.uscourts.gov/statistics-reports/federal-judicial-caseload-statistics-

2019\#: :text=Civil\%20Filings,rose\%202\%20percent\%20to\%20150\%2C936 (last visited Jan. 8, 2021)

(795,926 terminated cases).

${ }^{609}$ Executive Agency Courts, supra note 605.

6105 U.S.C.A. § $5372 \mathrm{~b}$ (West).

61126 U.S.C.A. $\$ 7441$.

${ }^{612}$ Crowell v. Benson, 285 U.S. 22, 27, 49-51, 63-65 (1932). See also Pfander, supra note 7, at 658-59.

${ }^{613} I d$. at 659 (citing Richard H. FALlON, JR., ET AL., HART \& WESCHLER's THE FEDERAL COURTS AND THE FEDERAL SYSTEM 367-377 (5th ed. 2003); Fallon, Jr., supra note 7, at 946-48, 986-91).

614 The U.S. Immigration Courts, for instance, are firmly entrenched inside the Department of Justice and not independent. There are no cases from the Supreme Court or Courts of Appeals stating that they are Article I courts; nor does the legislation creating them indicate such. In addition, there are several law review articles indicating they are not Article I courts. See, e.g., Leonard Birdsong, Reforming the 
Some are themselves recognized as independent agencies within a department, with the power to rule on decisions issued by other agencies.

The Occupational Safety and Health Review Commission, for instance, created in 1970, rules on cases forwarded by the Department of Labor which relate to disputes over the Occupational Safety and Health Administration's safety and health inspections. ${ }^{615}$ The Executive Office for Immigration Review at the U.S. Department of Justice administers the immigration court system. Once the Department of Homeland Security charges an alien with violating immigration laws, EOIR determines whether the person is removable and/or whether they qualify for relief. ${ }^{616}$ EOIR's Office of the Chief Immigration Judge has some 350 immigration judges who hold removal hearings as well as other administrative proceedings in 60 immigration courts across the country ${ }^{617}$ The appellate entity, the Board of Immigration Appeals, hears appeals from certain DHS determinations and immigration judge decisions, most of which involve orders of removal or applications for relief. Certain orders are designated as precedential, governing similarly-situated cases going forward. ${ }^{618}$ The EOIR also includes an Office of the Chief Administrative Hearing Officer, which oversees cases involving sanctions on employers for hiring unauthorized workers. ${ }^{619}$ The Administrative Procedure Act sets the rules that govern administrative agencies, with subsequent review of their decisions in Article III courts. ${ }^{620}$

\section{CONCLUDING REMARKS}

For decades, scholars have wrestled with how Article I courts, in the absence of life tenure during good behavior, undiminished compensation, and appointment with the advice and consent of the Senate, could as a constitutional matter hear categories of cases and controversies reserved to Article III. A handful have endorsed the theory of appellate review: as long as cases can be adequately examined by an Article III court, Congress has some leeway in the tribunals it erects. ${ }^{621}$ Others considered the operation of Article I entities to be merely necessary. ${ }^{622}$

In 2004, Professor James Pfander offered instead a distinction rooted in the constitutional text: between the inferior courts referenced in Article III and the inferior tribunals of Article I, distinguishing them by, in the case of the former, the exercise of the judicial power of the United States. He noted, as a condition for the latter, their subservience to Article III. Pfander's account is both persuasive and helpful; however, it leaves open the question of how to think about courts that are neither Article I entities nor subservient to the Supreme Court, such as territorial, consular, or occupation courts.

\footnotetext{
Immigration Courts of the United States: Why Is There No Will to Make It an Article I Court?, 19 BARRY L. REV. 17 (2013).

${ }^{615}$ See Occupational Safety and Health Act of 1970, Pub. L. No. 91-596, 84 Stat. 1590 (codified as amended at 29 U.S.C.A. $\$ \S 651-678)$.

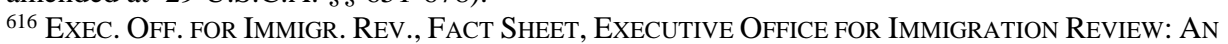

AGENCY GuIDE 1 (Dec. 2017), https://www.justice.gov/eoir/page/file/eoir_an_agency_guide/download.

${ }^{617} I d$.

${ }^{618} I d$.

${ }^{619} I d$.

${ }^{620}$ Administrative Procedure Act, ch. 324, 60 Stat. 237 (1946) (codified as amended in scattered sections of 5 U.S.C.A.).

${ }^{621}$ See, e.g., Fallon, Jr., supra note 7, at 943-949; and Redish, Legislative Courts, supra note 7, at 226-28.

${ }^{622}$ See, e.g., Bator, supra note 7, at 265.
} 
In his narrow emphasis on the Article III/I divide, Pfander did not consider the possibility that either Article IV or Article II might provide an alternative constitutional locus. Of these, territorial courts have come in for their fair share of criticism. ${ }^{623}$ Perhaps most recently, Professor William Baud has attempted to bridge the divide by suggesting a distinction among courts based on the specific power being exercised: i.e., when courts exercise an executive power, they are an Article I entity, whereas when they exercise a judicial power, they must be understood as the judicial power of the sovereign in question. ${ }^{62}$ Thus, states, tribal entities, and the federal government, as well as territories, constitute separate governments, for which a judicial power can be exercised in parallel with each other.

In some ways, Baud's approach gets us further than Pfander, in that it accounts for territorial entities. But it still does not address the existence of other federal tribunals, such as consular courts, slave courts, extraterritorial entities, or courts of occupation. When all federal courts are taken into account, a very different picture emerges - one rooted in the Constitutional text.

As this Article has demonstrated, the federal judicial system, is comprised of general and specialized Article III(1) courts that carry the judicial power of the United States and, as such, constitute the third branch. It also includes specialized courts introduced by Congress consistent with Article I(8)(9) and other enumerated powers, and territorial courts derived from Article IV(3). In addition, it is constituted by treatybased extraterritorial courts rooted in both Article II(2) and Article I(8)(3) and courts of occupation introduced by the President consistent with the Article II(2) Commander-in-Chief authority. All of these tribunals have a constitutional nexus. Many — but not all — of them are established by Congress. Many — but not all—of them are inferior to the Supreme Court. Some - but not all of them-exercise the judicial power of the United States. All of them adjudicate matters of law in ways that impact the rights of U.S. citizens. It is time to jettison the prior models and adopt, instead, a more robust understanding of the federal judicial system, grounded the Constitutional text.

${ }^{623}$ See, e.g., Currie, supra note 7, at 719 (calling the Supreme Court's acceptance of territorial courts as "the first step down the road to perdition"); Lawson, supra note 7, at 893 (referring to Marshall's decision in Cantor as "fatuous").

${ }^{624}$ See Baude, supra note 6. 